UNIVERSIDADE DE SÃO PAULO

FACULDADE DE FILOSOFIA, LETRAS E CIÊNCIAS HUMANAS

DEPARTAMENTO DE LETRAS CLÁSSICAS E VERNÁCULAS

PROGRAMA DE PÓS-GRADUAÇÃO EM FILOLOGIA E LÍNGUA PORTUGUESA

ROSICLEIDE RODRIGUES GARCIA

A entoação do dialeto caipira do Médio Tietê:

reconhecimento, características e formação

- versão corrigida - 

UNIVERSIDADE DE SÃO PAULO

FACULDADE DE FILOSOFIA, LETRAS E CIÊNCIAS HUMANAS

DEPARTAMENTO DE LETRAS CLÁSSICAS E VERNÁCULAS

PROGRAMA DE PÓS-GRADUAÇÃO EM FILOLOGIA E LÍNGUA PORTUGUESA

\title{
A entoação do dialeto caipira do Médio Tietê: reconhecimento, características e formação \\ - versão corrigida -
}

Rosicleide Rodrigues Garcia

\begin{abstract}
Tese apresentada ao Programa de PósGraduação em Filologia e Língua Portuguesa do Departamento de Letras Clássicas e Vernáculas da Faculdade de Filosofia, Letras e Ciências Humanas da Universidade de São Paulo, para a obtenção do título de Doutora em Letras.
\end{abstract}

Orientador: Prof. Dr. Waldemar Ferreira Netto De acordo 


\section{Ficha catalográfica}

Autorizo a reprodução e divulgação total ou parcial deste trabalho, por qualquer meio convencional ou eletrônico, para fins de estudo e pesquisa, desde que citada a fonte.

Catalogação da Publicação

Serviço da Biblioteca e Documentação

Faculdade de Filosofia, Letras e Ciências Humanas da

Universidade de São Paulo

Garcia, Rosicleide Rodrigues

A entoação do dialeto caipira no Médio Tietê: reconhecimento, características e formação / Rosicleide Rodrigues Garcia; Orientador: Waldemar Ferreira Netto - São Paulo, 2015.

142f: I1

Tese (Doutorado) - Faculdade de Filosofia, Letras e Ciências Humanas da Universidade de São Paulo.

Departamento de Letras Clássicas e Vernáculas. Área de concentração: Filologia e Língua Portuguesa.

1. Entoação. 2. Prosódia. 3. Dialeto caipira do Médio Tietê. 4. Finalização plagal

I. Título. II. FERREIRA NETTO, Waldemar. 


\section{FOLHA DE APROVAÇÃO}

GARCIA, Rosicleide Rodrigues

A entoação do dialeto caipira no Médio Tietê: reconhecimento, características e formação

Tese apresentada à Faculdade de Filosofia, Letras e Ciências Humanas da Universidade de São Paulo, para a obtenção do título de Doutora em Letras.

Aprovado em 09 de junho de 2015.

\section{Banca Examinadora}

Prof. Dr. Waldemar Ferreira Netto

Universidade de São Paulo (USP)

Prof. Dr. Manoel Mourivaldo Santiago Almeida

Universidade de São Paulo (USP)

Prof. Dr. Mário Eduardo Viaro

Universidade de São Paulo (USP)

Prof. Dr. Natalina Sierra Assêncio Costa

Universidade Estadual de Mato Grosso do Sul (UEMS)

Prof. Dr. Emílio Pagotto

Universidade Estadual de Campinas (UNICAMP) 
À minha família, meu oceano de possibilidades e crescimento. 


\section{Agradecimentos}

Em minha dissertação de mestrado, eu comparei a construção do conhecimento a de uma casa, por ser algo trabalhoso, mas satisfatório. Nesta tese, eu devo comparar à construção de um Empire State Building, pois a edificação da ciência deve ser vista e realizada com bases realmente sólidas, compromissada, algo que recai sobre os nossos ombros, tal qual o sentimento de um engenheiro que precisa concretizar o seu trabalho e que possa sustentar a todos que adentrarem nessa construção de forma segura.

E é exatamente esse sentimento que tive durante todo o desenvolvimento do trabalho, pois, mais do que nunca, eu tive de aprender assuntos novos, expandir o que eu já sabia e responsabilizar-me pelas conclusões tidas, pois, como sabido, uma tese de doutorado é o desenvolvimento puro da ciência, é um passo que implica muita reflexão e responsabilidade.

Por isso, por terem me ajudado a não apenas escrever uma tese, mas a me construir também como ser reflexivo, devo agradecer a Deus e às minhas colunas de sustentação (afinal, não se constrói um prédio sem as colunas): primeiramente, ao meu orientador Waldemar Ferreira Netto, que pacientemente me ensinou os primeiros passos dos estudos de entoação e prosódia, e me conduziu durante todo o trabalho de pesquisa. Ao prof. Dr. Manoel Mourivaldo Santiago Almeida, por sempre acreditar em mim e me proporcionar a chance de crescimento intelectual. Ao amigo Cláudio Roberto Giovani, que me ensinou estatística e demais cálculos, até então impossíveis para mim. Aos professores Emílio Pagotto, Natalina S. A. Costa e Mário E. Viaro, que me auxiliaram a lapidar o trabalho. E a todos os informantes que, além de terem doado suas entrevistas, proporcionaram-me momentos aprazíveis e inesquecíveis.

Ainda como base principal e auxiliando-me emocionalmente, devo agradecer com todo carinho ao meu Fábio e à Mariana, que sempre estiveram ao meu lado, mesmo quando eu não estava, e me apoiaram de todas as maneiras possíveis para a produção dessa tese. Desculpem-me pela ausência.

Aos meus pais, Maria e a Osvaldo, por ajudarem-me com a Mariana, e dando apoio quando tudo parecia mais difícil. Assim como aos amigos da Escola Técnica Walter Belian, à minha linda equipe de Língua Portuguesa (Andrezza, Bruna, Cláudia, Patrícia, Thalita), e aos meus amigos-irmãos Rony, Patrícia, Daniela, Marcelo, Gilberto, Glauce, Bernadete, Milton, Marisa, Vagner, Iara, Jeferson, Cristiane, Cintia, Luciano, Omar e Raquel e às crianças: obrigada pela alegria. E à USP, pela conquista de um sonho. 


\section{Resumo}

GARCIA, R.R. A entoação do dialeto caipira no Médio Tietê: reconhecimento, características e formação. 2015. 145f. Tese (Doutorado) - Faculdade de Filosofia, Letras e Ciências Humanas, Universidade de São Paulo, São Paulo, 2015.

Esta tese de doutorado A entoação do dialeto caipira no Médio Tietê: reconhecimento, características e formação faz parte do Projeto ExProsodia, em auxílio ao PHPP (Projeto História do Português Paulista), que objetiva analisar o português paulista falado no interior do estado. Sendo um dos trabalhos que está dando embasamento a ele, esta pesquisa subsidia os estudos do idioma, trazendo, além do exame da entoação, um breve histórico do Brasil e das cidades interioranas paulistas e portuguesas, de modo a entendermos como foi estabelecido o dialeto caipira nessas localidades. Tendo isso feito, avaliou-se a entoação de falantes do Médio Tietê por meio de análise automatizada promovida pelo ExProsodia. Seguindo a linha de pesquisa de Ferreira Netto (2008), examinou-se a fala dos informantes a partir da análise de $\mathrm{f}_{0}$, particularizando dela o tom médio (TM) e o tom final (TF). Para isso, foram selecionados 40 entrevistados, sendo 28 de sete cidades que compõem o Médio Tietê (Santana de Parnaíba, Pirapora do Bom Jesus, Porto Feliz, Tietê, Capivari, Itu, Piracicaba), e 12 de três cidades do norte de Portugal (Braga, Bragança e Vila Real), além de 10 gravações ( 5 vozes masculinas e femininas) de jornalistas do programa SPTV da emissora de televisão Rede Globo - tomados como fala neutra (BARBOSA, 2002, p.36) para serem usados como controle. Em cada cidade mencionada, buscaram-se 4 informantes, sendo dois homens e duas mulheres com idades iguais ou superiores a 60 anos, de baixo ou nenhum grau de escolaridade e moradores vitalícios de suas regiões. De seus depoimentos foram colhidas 5 frases para observação, totalizando o valor de 220 dados. Desta forma, por meio de aplicativos especializados (SFS $e$ Audacity), e com especial uso do ExProsodia ${ }^{\circledR}$ para geração de valores para o cálculo estatístico, foi possível verificar que o TM e o TF do dialeto caipira apresentam, em diversas análises, características comuns ao do controle e ao dos falantes de Portugal; ademais, observou-se que a finalização apresentada pelos informantes brasileiros e portugueses tendem a ser menos acentuada, caracterizando um traço plagal na fala. Os mesmos resultados também foram observados com os estudos de Costa e Baz (ambos de 2011), em que foram analisadas as falas de índios guatós e guaranis paraguaios. Sendo assim, este estudo pode gerar algumas conclusões: primeiramente, a finalização autêntica é uma variação entoacional, já que a plagal não é uma característica própria de uma região, logo, como ela é encontrada nos falares de pessoas com baixa ou nenhuma escolaridade, entende-se que este seria um traço comum da fala, o qual o dialeto caipira também mantém. Além disso, como o caipira apresenta o TM e o TF similares ao do controle, demonstra-se que seus falares possuem inflexões como em outras falas, não sendo plano ou igual; e essas considerações atualizam a informação de Amaral (1955, p. 45) sobre esse assunto.

Palavras-chave: Entoação, Prosódia, Dialeto Caipira do Médio Tietê, Finalização Plagal. 


\begin{abstract}
GARCIA, R.R. The intonation of the caipira dialect in the Médio Tietê: recognition, characteristics and formation. 2015. 145f. Tese (Doutorado) - Faculdade de Filosofia, Letras e Ciências Humanas, Universidade de São Paulo, São Paulo, 2015.
\end{abstract}

This doctoral dissertation aims at analyzing the Portuguese dialect (caipira) spoken in the region of Middle Tietê, on the Brazilian state of São Paulo. Entitled "The intonation of the caipira dialect in the Middle Tietê: recognition, characteristics and formation", this thesis is part of the Project ExProsodia in aid to PHPP (Project History of Paulista Portuguese), providing groundwork to other studies of Portuguese dialects. Besides examining aspects of intonation, this work offers a concise historical analysis on how the caipira dialect was established in Brazil, São Paulo and the Portuguese countryside. The empirical material consisted of speeches from 40 interviewees in 7 cities of the Middle Tietê region (28 interviewees) and 3 cities of the Northern Portugal region (12 interviewees). Additionally, 10 recordings of journalists from a major TV news broadcasting in São Paulo (SPTV by Rede Globo) were adopted as controls, based on the assumption of neutral speech (BARBOSA, 2002 , p.36). Four interviewees were selected per city ( 2 men and 2 women), with the inclusion criteria of being at least 60 years old, having low or no formal education, and being ligelong resident at the surveyed areas. Five phrases were analysed per individual, amounting to a total of 220 data samples. The intonations of these interviewees were processed through specialized computer applications (SFS and Audacity) and the special use of an automated analytical tool called ExProsodia ${ }^{\circledR}$, which statistically discriminated the various tones of the caipira dialect. Following Ferreira Netto's research (2008), speeches were analyzed by selecting the midtones (TM) and the final tones (TF), in the so-called f0 analysis. Common features were observed among the Portuguese interviewees and the Brazilian controls, whereas the phrasal finalization of Brazilian and Portuguese interviewees tended to be less marked, and featured by a plagal trace speech. Similar results were observed by Costa (2011) and Baz (2011), where the lines of Paraguayan Guarani Indians and Guatós Indians were analyzed. This thesis concludes that the authentic finalization is an intonational variation, because the plagal finalization is a region-independent feature occurring in the dialects of individuals with low or no formal education. Hence, the plagal finalization is suggested to be a common trait of speech, also kept by the caipira dialect. Furthermore, as the caipira dialect presents TM and TF similar to the control, it features inflections which are neither plane or equal; such finding warrants an update on Amaral's information on the subject (1920, p. 56).

Keywords: Intonation, Prosody, Caipira dialect from Mêdio Tietê, Plagal finalization. 


\section{Lista de figuras}

Figura 1 - $\quad$ Mapa das regiões propostas por Diégues (1960, p. 473) ......................... 31

Figura 2 - $\quad$ Principais bandeiras realizadas pelo Brasil durante os séculos XVII e XVIII... 33

Figura 3 - À esquerda, divisões das bacias hidrográficas do Estado de São Paulo; à direita, destaque para as regiões do Médio Tietê.

À direita, localização das cidades de Braga, Vila Real e Bragança no mapa de Portugal. À esquerda, a área mais clara é a retomada do

Figura 4 - Condado Portucalense em 1128. Neste ano, Afonso Henrique derrota a sua mãe na Batalha de S. Mamede, e, em 1139, torna-se rei e consolida a autonomia de Portugal, alargando para o sul os limites da Reconquista.

Figura 5 - Vista do centro histórico 50

Figura 6 - Dados cartográficos de Santana de Parnaíba. 51

Figura 7 - Vista aérea da cidade 52

Figura 8 - Dados cartográficos de Pirapora do Bom Jesus. 52

Figura 9 - $\quad$ O salto de Itu, 1886, por Almeida Jr. ..................................................... 53

Figura 10 - Dados cartográficos de Itu.............................................................. 53

Figura 11 - Porto Feliz retratada em 1826.......................................................... 54

Figura 12 - $\quad$ Dados cartográficos de Porto Feliz......................................................... 55

Figura 13 - Vista aérea atual da cidade........................................................... 55

Figura 14 - Dados cartográficos de Piracicaba..................................................... 56

Figura 15 - Vista aérea de Capivari...................................................................... 56

Figura 16 - Dados cartográficos de Capivari......................................................... 57

Figura 17 - Vista aérea de Tietê............................................................................ 57

Figura 18 - Dados cartográficos de Tietê............................................................... 58

Figura 19 - Vista da cidade murada no castelo de Bragança...................................... 59

Figura 20 - Movimento da Reconquista nos séculos XI e XII.................................. 60

Figura 21 - Arco da Porta Nova, foto atual de uma das entradas da muralha............. 61 
Figura 22 - $\quad$ Mapa de Braga de 1594.

Figura 23 - Uma das fragas do Santuário de Panoia. Nela estão talhados três receptáculos utilizados para batizado após sacrifício de animais. 62

Figura 24 - $\quad$ Palácio de Morgado de Mateus................................................................ 63

Figura 25 - Esculturas, monumentos e objetos em tamanhos exagerados de Itu........ 71

Figura 26 - Igreja da Matriz, na Praça Padre Miguel, Centro de Itu - 1950.............. 72

Frente da Igreja Matriz de Pirapora do Bom Jesus. Esse local, de onde Figura 27 - se está tirando a fotografia e se vê uma pequena vegetação florida, faz parte da reforma realizada em 1995, chamada hoje de "Praça do Encontro" por causa das romarias....................................................... 72

Figura 28 - Vista aérea do Castelo de Bragança e a vila murada............................... 73

Figura 29 - Combinação de acordes em dó e sol........................................................ 88 


\section{Lista de gráficos}

Gráfico 1 - Caracterização da decomposição de $\mathrm{f}_{0}$ em quatro elementos (sustentação, finalização, foco/ênfase e acento lexical)

Gráfico 2 - Caracterização das variações de tons

Gráfico 3 - Caracterização do processo de entoação do gênero musical Fandango Paulista, de Rossini Tavares de Lima, da obra Folclore de São Paulo, 1954 (FERREIRA NETTO, 2010).

Gráfico 4 - Caracterização do processo de entoação de uma música da tribo Kaiowá, retirada da obra de Helza Camêu, Introdução ao estudo da música indígena brasileira, 1977 (FERREIRA NETTO, 2010).

Gráfico 5 - Comparação do Tom Médio (TM) em unidade cps medido em Hertz (linha vertical) entre as cidades do Médio Tietê, Portugal e o controle (linha horizontal)

Gráfico 6 - Comparação de TM entre categorias - mulheres e homens - em unidade cps medido em Hertz (linha vertical) entre as cidades do Médio Tietê, Portugal e o controle (linha horizontal)

Gráfico 7 - Comparação do Tom Final (TF) medido em Hertz (linha vertical) entre as cidades do Médio Tietê, Portugal e o controle (linha horizontal).

Gráfico 8 - Comparação de TF entre categorias - mulheres e homens - em unidade cps medido em Hertz (linha vertical) entre as cidades do Médio Tietê, Portugal e o controle (linha horizontal)

Gráfico 9 - Comparação de coeficientes entre os informantes das cidades. $\mathrm{Na}$ linha horizontal, há o nome das cidades; na horizontal, as médias geradas a partir do cálculo do coeficiente do TM e TF de cada informante. Na legenda, H significa Homem e M, mulher.

Gráfico 10 - Comparação entre as finalizações dos falantes do Médio Tietê, Portugal e controle. $\mathrm{O}$ eixo vertical refere-se às médias medidas em Hertz, e a horizontal refere-se ao Tom Médio e ao Tom Final decorrentes das falas.

Gráfico 11 - Comparação entre as finalizações dos falantes masculinos do Médio Tietê, Portugal e controle. O eixo vertical refere-se às médias medidas em Hertz, e a horizontal refere-se ao Tom Médio e ao Tom Final decorrentes das falas

Gráfico 12 - Comparação entre as finalizações dos falantes femininos do Médio Tietê, Portugal e controle. 
Exemplo da entoação frasal masculina (H1/FR1) de Itu. Frase: "A juventude era uma coisa gostosa, né... nóis tinha a nossa praça, nóis frequentava a praça, nóis andava pra praça, arrumava namorada, e assim foi indo... tinha o coreto, tinha a nossa banda união que era bastante afamada, e assim... tocando a vida pra frente." A média do TM é 173 e do TF é 171

Gráfico 14 - Exemplo da entoação frasal feminina (M2/FR1) de Itu. Frase: "E antigamente a gente não tinha televisão na casa da gente, então a gente pagava pra quem que tinha televisão lá na vila... que eu morei na vila rica, né... então tinha duas ou três pessoa que tinha televisão, então a gente pagava... pra assistir televisão como se fosse no cinema... então ali era a diversão da gente. " A média do TM é 219 e do TF é 213

Gráfico 15 - Exemplo da entoação frasal masculina (H1/FR4) de Bragança. Frase: "Trabalhar, tu o que que queria... estudar até a quarta classe e depois trabalhar... comecei a trabalhar de carpinteiro, ué, fiz carpintaria depois fiz ele... a escola no meu tempo era rapazes prum lado e raparigas pro outro... e não havia misturas." A média do TM é 185 e do TF é 188

Gráfico 16 - Exemplo da entoação frasal feminina (M1/FR3) de Bragança. Frase: "Era a escola... $\mathrm{Na}$ escola, a gente hoje na escola tem tudo... antigamente a gente estava descalça e com frio e aprendias... e as professoras carregavam numas pessoas e hoje num se pode bater num filho.” A média do TM é 196 e do TF é 190

Gráfico 17 - Exemplo da entoação frasal masculina (M1/FR3) do Controle. Frase: "Administração de empresas é o curso que tem o maior número de alunos no estado, são duzentos e vinte mil, a gente fala agora do vestibular, e um dos motivos que atrai tanta gente é que administração é um... é um curso curinga, né... dá pra trabalhar com recursos humanos, com marketing, virar executivo, abrir o seu próprio negócio, são muitas as opções." A média do TM é 144 e do TF é 88...

Gráfico 18 - Exemplo da entoação frasal feminina (M2/FR3) do Controle. Frase: "É sim... um administrador pode dirigir uma empresa, cuidar do marketing, trabalhar com sustentabilidade, apostar num mercado financeiro, formar uma carreira abrangente e uma formação ampla... nos quatro anos de curso o aluno estuda de filosofia a matemática." A média do TM é 249 e do TF é 176

Gráfico 19 - Comparação entre as finalizações das entrevistadas corumbaenses.......

Gráfico 20 - Comparação entre o canto e a fala dos homens e mulheres guaranis paraguaios (BAZ, 2011, p. 153) 


\section{Lista de Tabelas}

Tabela 1 - Tabela diatônica de dó maior............................................................... $\quad$ (

Tabela 2 - $\quad$ Comparação do Tom Médio (TM) em unidade cps medido em Hertz entre as cidades do Médio Tietê, Portugal e o controle.

Tabela 3 - $\quad$ Resultados do teste estatístico ANOVA para o TM. Houve variação significativa entre os todos informantes: $\mathrm{P}<0,05$ e $\mathrm{F}_{0}(2,35)>\mathrm{F}_{\mathrm{c}}$ $(1,87)$

Tabela 4 - Resultados do teste estatístico ANOVA para o TM. Houve variação significativa entre os informantes do Médio Tietê: $\mathrm{P}<0,05$ e $\mathrm{F}_{0}(2,92)$ $>\mathrm{F}_{\mathrm{c}}(2,16)$

Tabela 5 - Resultados do teste estatístico ANOVA para o TM. Houve variação significativa entre os informantes do Médio Tietê e Portugal: $\mathrm{P}<0,05$ e $F_{0}(2,88)>F_{c}(1,92)$

Tabela 6 - Comparação do Tom Médio (TM) em unidade cps medido em Hertz somente entre homens das cidades do Médio Tietê, Portugal e controle.

Tabela 7 - Resultados do teste estatístico ANOVA para o TM. Houve variação não significativa entre os informantes do Médio Tietê: $\mathrm{P}>0,05$ e $\mathrm{F}_{0}$ $(11,92)>F_{c}(2,13)$

Tabela 8 - Resultados do teste estatístico ANOVA para o TM. Houve variação não significativa entre os informantes do Médio Tietê e Portugal: $\mathrm{P}$ $>0,05$ e $F_{0}(7,41)>F_{c}(1,92)$

Tabela 9 - $\quad$ Comparação do Tom Médio (TM) em unidade cps medido em Hertz somente entre mulheres das cidades do Médio Tietê, Portugal e controle.

Tabela 10 - Resultados do teste estatístico ANOVA para o TM. Houve variação significativa entre as informantes do Médio Tietê: $\mathrm{P}<0,05$ e $\mathrm{F}_{0}(6,28)$ $>\mathrm{F}_{\mathrm{c}}(2,13)$

Tabela 11 - Resultados do teste estatístico ANOVA para o TM. Houve variação não significativa entre as informantes do Médio Tietê e Portugal: $\mathrm{P}$ $>0,05$ e $\mathrm{F}_{0}(5,56)>\mathrm{F}_{\mathrm{c}}(1,92)$

Tabela 12 - Comparação do Tom Médio (TM) entre homens das cidades do Médio Tietê e Portugal. Os dados foram gerados a partir do controle da tabela 6

Tabela 13 - Comparação do Tom Médio (TM) entre mulheres das cidades do Médio Tietê e Portugal. Os dados foram gerados a partir do controle 
da tabela 9

Tabela 14 - Comparação do Tom Médio (TM) em unidade cps medido em Hertz entre homens e mulheres das cidades do Médio Tietê.

Tabela 15 - Resultados do teste estatístico F para o TM. Houve variação não significativa entre os informantes do Médio Tietê: $\mathrm{P}>0,05$ e $\mathrm{F}_{0}(0,46)$ $>F_{c}(0,31)$.

Tabela 16 - Comparação do Tom Médio (TM) em unidade cps medido em Hertz entre homens e mulheres das cidades de Portugal

Tabela 17 - Resultados do teste estatístico $\mathrm{F}$ para o TM. Houve variação significativa entre os informantes de Portugal: $\mathrm{P}<0,05$ e $\mathrm{F}_{0}(3,87)>\mathrm{F}_{\mathrm{c}}$ $(3,17)$

Tabela 18 - Comparação do Tom Médio (TM) em unidade cps medido em Hertz entre homens e mulheres do controle

Tabela 19 - Resultados do teste estatístico $F$ para o TM. Houve variação não significativa entre os informantes do controle: $\mathrm{P}>0,05$ e $\mathrm{F}_{0}(0,65)>\mathrm{F}_{\mathrm{c}}$ $(0,31)$

Tabela 20 - Comparação do Tom Médio (TM) em unidade cps medido em Hertz entre homens do Médio Tietê, Portugal e o controle

Tabela 21 - Resultados do teste estatístico F para o TM. Houve variação significativa entre os informantes do Médio Tietê e controle: $\mathrm{P}<0,05$ e $\mathrm{F}_{0}(0,13)<\mathrm{F}_{\mathrm{c}}(0,31)$.

Tabela 22 - Resultados do teste estatístico F para o TM. Houve variação não significativa entre os informantes de Portugal e controle: $\mathrm{P}>0,05$ e $\mathrm{F}_{0}$ $(0,97)>F_{c}(0,31)$

Tabela 23 - Resultados do teste estatístico F para o TM. Houve variação significativa entre os informantes de Portugal e Médio Tietê: $\mathrm{P}<0,05$ e $\mathrm{F}_{0}(0,13)<\mathrm{F}_{\mathrm{c}}(0,31)$

Tabela 24 - Comparação do Tom Médio (TM) em unidade cps medido em Hertz entre mulheres do Médio Tietê, Portugal e o controle....

Tabela 25 - Resultados do teste estatístico F para o TM. Houve variação significativa entre as informantes do Médio Tietê e controle: $\mathrm{P}<0,05$ e $\mathrm{F}_{0}(0,18)<\mathrm{F}_{\mathrm{c}}(0,31)$

Tabela 26 - Resultados do teste estatístico F para o TM. Houve variação significativa entre as informantes de Portugal e controle: $\mathrm{P}<0,05$ e $\mathrm{F}_{0}$ $(0,16)<\mathrm{F}_{\mathrm{c}}(0,31)$

Tabela 27 - Resultados do teste estatístico F para o TM. Houve variação não 
significativa entre as informantes do Médio Tietê e Portugal: $\mathrm{P}>0,05$ e $\mathrm{F}_{0}(1,11)<\mathrm{F}_{\mathrm{c}}(3,17)$

Tabela 28 - Comparação do Tom Final (TF) medido em Hertz entre as cidades do Médio Tietê, Portugal e o controle SP

Tabela 29 - Resultados do teste estatístico ANOVA para o TF. Houve variação não significativa entre os informantes de todas as regiões: $\mathrm{P}>0,05$ e $\mathrm{F}_{0}$ $(1,84)<F_{c}(1,87)$

Tabela 30 - Resultados do teste estatístico ANOVA para o TF. Houve variação não significativa entre os informantes do Médio Tietê: $\mathrm{P}>0,05$ e $\mathrm{F}_{0}(1,79)$ $<\mathrm{F}_{\mathrm{c}}(2,16)$

Tabela 31 - Resultados do teste estatístico ANOVA para o TF. Houve variação significativa entre os informantes do Médio Tietê e Portugal: $\mathrm{P}<0,05$ e $\mathrm{F}_{0}(2,02)>\mathrm{F}_{\mathrm{c}}(1,92)$

Tabela 32 - Comparação do Tom Final (TF) dos homens medido em Hertz nas cidades do Médio Tietê, Portugal e controle

Tabela 33 - Resultados do teste estatístico ANOVA para o TF. Houve variação significativa entre os informantes masculinos de todas as localidades: $\mathrm{P}<0,05$ e $\mathrm{F}_{0}(2,60)>\mathrm{F}_{\mathrm{c}}(1,92)$

Tabela 34 - Resultados do teste estatístico ANOVA para o TF. Houve variação não significativa entre os informantes masculinos do Médio Tietê: $\mathrm{P}>0,05$ e $F_{0}(2,23)<F_{c}(2,24)$

Tabela 35 - Resultados do teste estatístico ANOVA para o TF. Houve variação significativa entre os informantes masculinos do Médio Tietê e Portugal: $\mathrm{P}<0,05$ e $\mathrm{F}_{0}(2,32)>\mathrm{F}_{\mathrm{c}}(1,98)$

Tabela 36 - Resultados do teste estatístico ANOVA para o TF. Houve variação significativa entre os informantes masculinos do Médio Tietê e controle: $\mathrm{P}<0,05$ e $\mathrm{F}_{0}(2,35)>\mathrm{F}_{\mathrm{c}}(2,13)$.

Tabela 37 - Comparação do Tom Final (TF) das mulheres medido em Hertz nas cidades do Médio Tietê.

Tabela 38 - Resultados do teste estatístico ANOVA para o TF. Houve variação não significativa entre todos os informantes femininos: $\mathrm{P}>0,05$ e $\mathrm{F}_{0}(1,47)$ $<\mathrm{F}_{\mathrm{c}}(1,92)$.

Tabela 39 - Resultados do teste estatístico ANOVA para o TF. Houve variação não significativa entre os informantes femininos do Médio Tietê: $\mathrm{P}>0,05$ e $F_{0}(2,06)<F_{c}(2,24)$

Tabela 40 - Resultados do teste estatístico ANOVA para o TF. Houve variação não significativa entre os informantes femininos do Médio Tietê e 
Portugal: $\mathrm{P}>0,05$ e $\mathrm{F}_{0}(1,46)<\mathrm{F}_{\mathrm{c}}(1,98)$

Tabela 41 - Resultados do teste estatístico ANOVA para o TF. Houve variação não significativa entre os informantes femininos do Médio Tietê e o controle: $\mathrm{P}>0,05$ e $\mathrm{F}_{0}(2,04)<\mathrm{F}_{\mathrm{c}}(2,13)$....

Tabela 42 - Comparação do Tom Final (TF) entre homens das cidades do Médio Tietê e Portugal. Os dados foram gerados a partir do controle da tabela 32

Tabela 43 - Comparação do Tom Final (TF) entre as mulheres das cidades do Médio Tietê. Os dados foram gerados a partir do controle SP da tabela 37

Tabela 44 - Comparação do Tom Final (TF) entre mulheres e homens do Médio Tietê

Tabela 45 - Resultados do teste estatístico $F$ para o TF. Houve variação não significativa entre os informantes do Médio Tietê: $\mathrm{P}>0,05$ e $\mathrm{F}_{0}(0,60)>$ $\mathrm{F}_{\mathrm{c}}(0,31)$.

Tabela 46 - Comparação do Tom Final (TF) entre mulheres e homens do controle..

Tabela 47 - Resultados do teste estatístico $\mathrm{F}$ para o TF. Houve variação não significativa entre os informantes do controle: $P>0,05$ e $F_{0}(0,79)>F_{c}$ $(0,31)$

Tabela 48 - Comparação do Tom Final (TF) entre mulheres e homens de Portugal..

Tabela 49 - Resultados do teste estatístico $F$ para o TF. Houve variação não significativa entre os informantes de Portugal: $\mathrm{P}>0,05$ e $\mathrm{F}_{0}(0,43)>\mathrm{F}_{\mathrm{c}}$ $(0,31)$

Tabela 50 - Comparação do Tom Final (TF) entre homens do Médio Tietê, Portugal e controle

Tabela 51- Resultados do teste estatístico $F$ para o TF. Houve variação significativa entre os informantes masculinos do Médio Tietê e o controle: $\mathrm{P}<0,05$ e $\mathrm{F}_{0}(0,17)<\mathrm{F}_{\mathrm{c}}(0,31)$

Tabela 52 - Resultados do teste estatístico F para o TF. Houve variação significativa entre os informantes masculinos do Médio Tietê e Portugal: $\mathrm{P}<0,05$ e $\mathrm{F}_{0}(3,49)>\mathrm{F}_{\mathrm{c}}(3,17)$

Tabela 53 - Resultados do teste estatístico $F$ para o TF. Houve variação não significativa entre os informantes masculinos do controle e Portugal: $\mathrm{P}>0,05$ e $\mathrm{F}_{0}(0,60)>\mathrm{F}_{\mathrm{c}}(0,31)$

Tabela 54 - Comparação do Tom Final (TF) entre mulheres do Médio Tietê, Portugal e controle.

Tabela 55 - Resultados do teste estatístico F para o TF. Houve variação 
significativa entre as informantes do Médio Tietê e controle: $\mathrm{P}<0,05$ e $\mathrm{F}_{0}(0,27)<\mathrm{F}_{\mathrm{c}}(0,31)$

Tabela 56- Resultados do teste estatístico F para o TF. Houve variação significativa entre as informantes do Médio Tietê e Portugal: $\mathrm{P}<0,05$ e $\mathrm{F}_{0}(4,00)>\mathrm{F}_{\mathrm{c}}(3,17)$

Tabela 57- Resultados do teste estatístico $F$ para o TF. Houve variação não significativa entre as informantes do Médio Tietê e Portugal: $\mathrm{P}>0,05$ e $\mathrm{F}_{0}(1,11)>\mathrm{F}_{\mathrm{c}}(3,17)$

Tabela 58 - Comparação entre os informantes do Médio Tietê, Portugal e controle com valores medidos em Hertz.

Tabela 59- Comparação entre os informantes masculinos do Médio Tietê, Portugal e controle com valores medidos em Hertz.

Tabela 60 - Comparação entre os informantes femininos do Médio Tietê, Portugal e controle com valores medidos em Hertz. 


\section{Sumário:}

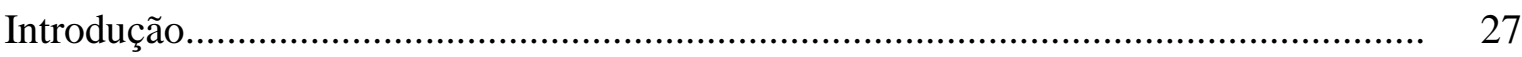

1. A motivação para os estudos da prosódia caipira........................................ 28

1.1. Brevíssimo histórico do português no Brasil................................... 29

1.1.1. A importância do bandeirantismo no Brasil..................... 32

1.2. Para o estudo do estabelecimento do idioma e suas variantes.......... 34

1.3. Variações do caipira e do Brasil....................................................... 39

2. O estudo da entoação caipira................................................................ 40

3. Concentração do estudo: informantes das cidades do Médio Tietê e do norte de

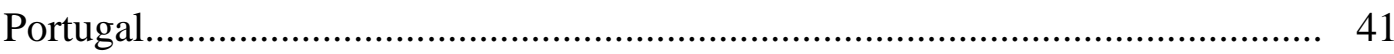

4. Apresentação da tese..................................................................................... 43

\section{CAPÍTUlO 1: As cidades do Médio Tietê, do norte de Portugal e a cultura caipira}

As cidades do Médio Tietê, do norte de Portugal e a cultura caipira.............................. 47

1. O surgimento das cidades do Médio Tietê.................................................... 49

1.1. Santana de Parnaíba.................................................................... 50

1.2. Pirapora do Bom Jesus.................................................................... 51

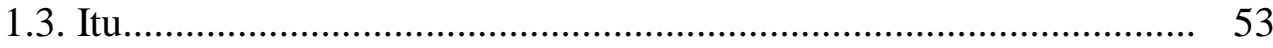

1.4. Porto Feliz................................................................................ 54

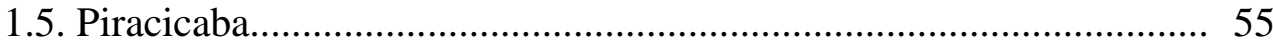

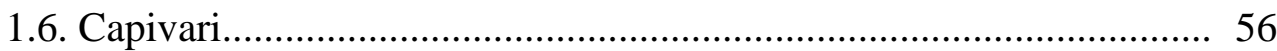

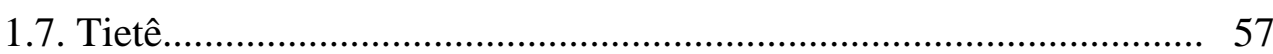

2. As cidades estudadas em Portugal............................................................. 58

2.1. Bragança.................................................................................. 59

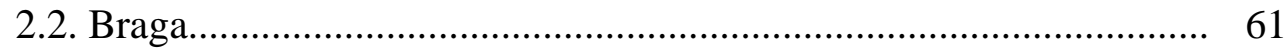

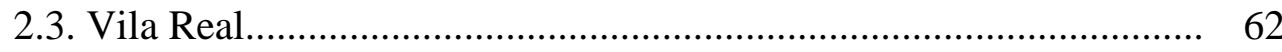

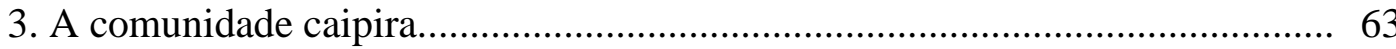

\section{CAPÍTULO 2: A metodologia e a pesquisa de campo}

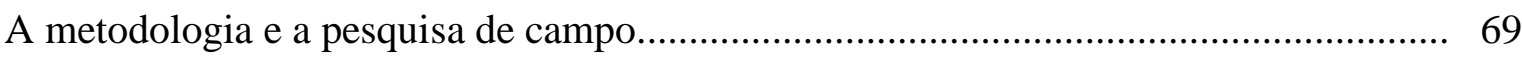

1. Buscando os informantes no Médio Tietê e em Portugal.............................. 70

1.1. Descrição dos informantes............................................................... 73 
1.1.1. Santana de Parnaíba............................................................ 74

1.1.2. Pirapora do Bom Jesus......................................................... 75

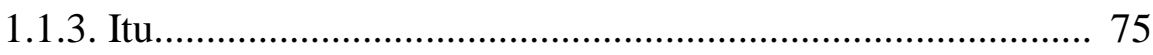

1.1.4. Porto Feliz...................................................................... 76

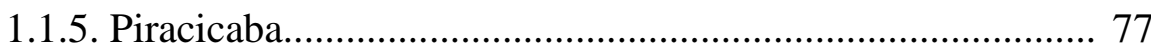

1.1.6. Capivari.......................................................................... 78

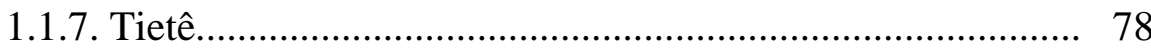

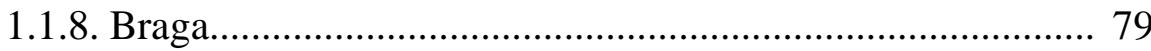

1.1.9. Bragança.................................................................. 80

1.1.10. Vila Real................................................................. 81

2. Seleção dos controles para comparação da entoação caipira........................... 81

2.1. Processo de coleta............................................................................ 82

3. O estudo de prosódia e a geração de dados pelo ExProsodia............................ 83

3.1. Considerando a hipótese $F_{0}$ como série temporal............................ 84

3.2. Utilizando o teste ANOVA para percepção das diferenças dialetais.. 86

3.3. A finalização autêntica e a plagal..................................................... 86

3.3.1. A música e os estudos de prosódia..................................... 87

3.3.2. As finalizações plagais no dialeto caipira e na fala dos

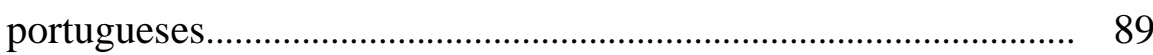

\section{CAPÍTULO 3: A entoação caipira}

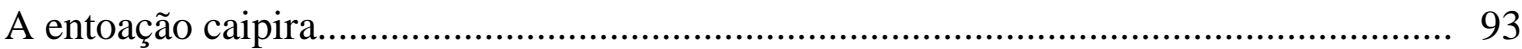

1. Objetos de análise: tom médio e tom final.................................................... 93

1.1. O tom médio................................................................................ 94

1.2. O tom final............................................................................. 107

1.3. O tom médio e o tom final em conjunto.......................................... 119

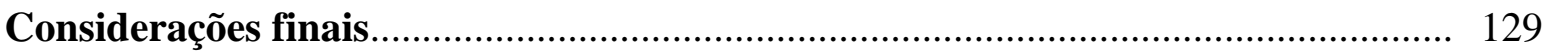

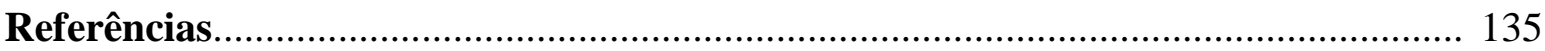




\section{Introdução}

Em 1920, Amadeu Amaral escreveu a obra $O$ dialeto caipira. Primeiro estudo a tratar das características de um falar (PINTO, 1978, p.XIX), o autor foi o precursor da dialetologia no Brasil, possibilitando, assim, que diversas outras pesquisas surgissem tendo-o como base. O Projeto História do Português Paulista (PHPP) ${ }^{1}$, que procura compreender a formação da comunidade linguística em São Paulo, promove o exame mais aprofundado dos estudos iniciados por Amaral, e esta tese faz parte desse projeto. Com o objetivo de caracterizar a entoação do dialeto caipira (DC) por meio da análise do $\mathrm{f}_{0}$, focaram-se o tom médio (TM) e tom final (TF) da fala dos informantes nas cidades do Médio Tietê - Santana do Paraíba, Pirapora do Bom Jesus, Itu, Piracicaba, Capivari, Tietê e Porto Feliz -, pois a hipótese era que esses elementos pudessem trazer indícios de uma marca dialetal.

As bases de pesquisa foram as narrativas de informantes idosos, para, por meio de suas informações, também contemplar o levantamento sócio-histórico e entendermos como se deu a formação das características entoacionais. Por isso, uma das argumentações desta tese seguirá alguns princípios de Amaral, que, no capítulo Elementos do Português no séc. XVI de sua obra, já informava que temos de iniciar pesquisas pela estrutura cultural e histórica da região para entender o estabelecimento do português nas cidades interioranas do estado de São Paulo:

[...] uma vez reconhecido que o fundo do dialeto representa um estado atrasado do português, e que sobre esse fundo se vieram sucessivamente entretecendo os produtos de uma evolução divergente, o seu acurado exame pode auxiliar a explicação de certos fatos ainda mal elucidados da fonologia, da morfologia e da sintaxe histórica da língua. (1955, p.56)

Ou seja, por meio desse trecho, observamos que o autor, por considerar a existência de conservações na língua que chamou de "estado atrasado do português", demonstra que um estudo abrangendo a compreensão das transformações sociais auxiliaria a entender as variações linguísticas do dialeto caipira (DC).

\footnotetext{
${ }^{1}$ PHPP é um conjunto articulado de subprojetos situados na Área da Linguística Histórica do Português e, portanto, na linha de pesquisa Estudos Diacrônicos e Sincrônicos do Português centrados nos objetivos de (a) coletar, organizar e disponibilizar corpora diacrônicos do Português Paulista, de modo a apoiar pesquisas sobre essa variedade; (b) analisar tais corpora em três eixos: (i) estudo da variação e mudança gramatical, dos ângulos funcionalista-cognitivista e gerativista, com ênfase nas classes de palavras e nas construções sintáticas; (ii) estudo da formação das variedades culta e popular e da difusão da popular na região do Médio Tietê, paralelamente ao traçado sócio-histórico do Português Paulista; (iii) estudo de gêneros discursivos e de processos de construção textual, sob as perspectivas crítico-discursiva e textualinterativa. Assim estruturado, o PHPP pretende promover um diálogo entre teorias linguísticas, indispensáveis nas pesquisas contemporâneas da Linguística Histórica. Fonte: http://phpp.fflch.usp.br/.
} 
Porém, deve-se ressaltar que $O$ dialeto caipira é uma obra pioneira, produzida de maneira particular e até artesanal, já que o autor, também poeta pós-parnasiano, registrou aquilo que captava nas conversas do dia a dia (DUARTE, 1950, 21-23). Obviamente, não se deve tirar-lhe o mérito, mas, como o próprio Amaral escreveu em sua introdução, eram necessárias mais pesquisas metódicas e referências para embasamento científico e expansão da obra que iniciou (AMARAL, 1955, 43-44).

Fazendo uma análise comparativa dialetológica utilizando outras pesquisas, percebe-se que diversas variantes tidas no DC também estão presentes em outras localidades por conta do legado da expansão do português no Brasil (vide item 1.2), confirmando a afirmação de Silveira Bueno (1967, p.160) quando diz que "não existe um só dos chamados 'brasileirismos' que não se possa encontrar nos bons autores portugueses". Por isso, apenas considerar os apontamentos de Amaral sem ampliar a pesquisa vai de encontro à própria vontade do autor, porquanto ele mesmo fizera esse pedido para sabermos se, muito além de ser o linguajar que traz consigo somente a realização do chamado "r forte" (retroflexo), quais seriam os elementos caracterizantes do DC.

De modo geral, o tema é extenso e pode ser dividido em vários assuntos, mas esta tese se propõe a focar na análise da prosódia, avaliando a entoação do dialeto caipira da região compreendida no Médio Tietê. Assim, pretende-se gerar dados suficientes para auxiliar estudos que categorizem e registrem a produção entoacional, a fim de que essa contribuição seja reconhecida nos meios acadêmicos e, sobretudo, constitua uma memória relevante dentro dos registros dos aspectos linguísticos/prosódicos brasileiros dos séculos XX e XXI do interior do estado de São Paulo.

\section{A motivação para os estudos da prosódia caipira}

Como dito acima, o DC possui diversas particularidades a serem estudadas, por isso, antes de concentrar a pesquisa no estudo de entoação, uma trajetória de análises prévias sobre o dialeto foi percorrida. Explica-se: o tema definitivo para esta tese surgiu ao encerramento da dissertação de mestrado Para o estudo da formação e expansão do dialeto caipira em Capivari (GARCIA, 2009), quando se observou que somente os exames sobre as variantes descritas por Amaral não seriam suficientes para determinar caracterizações do DC. Na ocasião, documentos novecentistas foram analisados embasando-se no capítulo sobre Fonética de $O$ dialeto caipira (1920, p.45) para, por meio dos parâmetros estabelecidos pelo autor, verificar as variantes presentes em ofícios 
do século XIX; além disso, foi feito um levantamento da variedade oral com informantes mais idosos e de baixo grau de escolaridade. Após serem considerados os registros, confirmou-se que as observações apontadas em 1920 ainda eram conservadas no DC pelos informantes contemporâneos.

Por essas mesmas variantes serem correntes na língua portuguesa falada no Brasil, ao final da dissertação, ocorreu a dúvida se elas igualmente existiriam em lugares onde não houvera a influência dos bandeirantes. E foi por meio de artigos, estudos e pesquisas já publicados sobre a língua portuguesa em diferentes regiões que se evidenciou que as variantes se encontram espalhadas por diversas localidades, fazendo parte da história e do cotidiano do nosso idioma.

Ou seja, para lançar-se finalmente aos estudos da entoação, averiguaram-se as variantes relacionadas por Amaral e em que localidades elas se apresentam. E essa breve pesquisa será colocada nesta introdução, já que, além de fazer parte dos estudos iniciais desta tese, ela ajudará a entender que as conservações, de um modo geral, são elementos também constituintes do DC.

\subsection{Brevíssimo histórico do português no Brasil}

Para entender a história do português no Brasil, primeiramente precisamos lembrar o processo de colonização, porque a introdução da língua em nosso país originou-se dele.

Segundo João Ribeiro (1901, p. 36), a colonização não aconteceu de maneira uniforme: em 1530, Martim Afonso de Souza e Pero Lopes percorreram o litoral brasileiro até adentrarem no sertão do Brasil:

A exploração ordenada por Martin Affonso de Sousa e a seu irmão Pero Lopes (1530) foi a mais precisa dos resultados: tocou sucessivamente no cabo de S. Agostinho, em Pernambuco, Todos os Santos, Rio de Janeiro, Cananéa; Pêro Lopes, só, foi até á ilha das Palmas (Rio da Prata); em todos esses lugares demorou-se algum tempo, e de volta, fundou S. Vicente e penetrou no interior até $\mathrm{S}$. André da Borda do Campo (S. Paulo).

Tendo as três benfeitorias em São Vicente, Piratininga e Pernambuco, D. João III dividiu as terras brasileiras em lotes para iniciar a colonização, por isso criaram-se doze capitanias hereditárias (1901, p. 37-38): São Vicente, Santo Amaro, Paraíba do Sul, Espírito Santo, Porto Seguro, Ilhéus, Bahia, Pernambuco, e quatro capitanias ao norte da capitania da Paraíba até o limite extremo do Maranhão. Porém, vinte anos após 
a constituição das capitanias, mesmo com as iniciativas da metrópole, estas mantinham apenas três mil colonos.

Em 1537, foram introduzidas cabeças de gado nas capitanias e a produção de açúcar em São Vicente, o que motivou o desenvolvimento da colônia. Nesse período, iniciou-se a mistura de etnias e o contato com as demais línguas.

Também foi nessa época que os colonos constituíram suas moradas nos morros, como forma de defesa aos constantes ataques franceses e de índios. Isto é, primeiramente surgiram as cidades no interior; somente após a reconquista das terras por causa das invasões francesas e holandesas, fundaram-se as cidades no litoral.

Assim, começaram a se abrir caminhos para o sertão do Brasil. As cidades do extremo sul do país, por exemplo, foram estabelecidas pelo interior a partir do século XVII devido à frequência dos viajantes abrindo novos caminhos e do comércio das missões (RIBEIRO, 1901, p.110). Em 1656, comandado pelo paulista Domingo Peixoto de Brito, fundou-se a povoação de Laguna, em Santa Catarina, avultando-a com deportados e, após, com a presença de habitantes que residiam nas ilhas de extensão portuguesa (Açores e Ilha da Madeira).

Em 1715, de Laguna saíram expedições para determinar caminhos por terra até a colônia de Sacramento, expandido o território até Rio Grande. Segundo o autor (RIBEIRO, 1904, p. 253),

Nesse ponto (que é o do Rio Grande) encontravam-se assim as duas expansões: a platina e a brasileira; não houve lucta no momento, e os Índios levados a Santa Catharina logo d'ahi voltaram para as suas missões levando o aviso de que não era licito aos hespanhoes invadir a região, já agora considerada portugueza.

Sendo assim, de acordo com o autor (1901, p.227), devido à história das capitanias e a extensão geográfica colonizada, era possível dividir o país em 5 grandes grupos:

1. Extremo Norte (do Amazonas ao Ceará);

2. Norte (Pernambuco, Rio Grande do Norte, Paraíba e Alagoas);

3. Centro (Sergipe, Bahia, Ilhéus, Porto Seguro);

4. Interior (São Paulo, Paraná, Goiás, Minas Gerais, Mato Grosso);

5. Rio de Janeiro (todo o litoral da parte sul do Brasil, excetuando São Paulo).

Segundo Ribeiro, o Norte e o Centro eram regiões ricas, de grande importância política e disputas territoriais; o Extremo Norte desenvolveu-se "separadamente do governo geral até os tempos de independência"; e o Interior, com o bandeirantismo, conquistou novas terras que, mais tarde, por razões financeiras e políticas, tornaram-se 
capitanias independentes de São Paulo. A única cidade litorânea de grande importância era o Rio de Janeiro.

Dentro desse contexto de formação cultural, Diégues Júnior, em sua obra Regiões culturais do Brasil (1960), por sua vez, compreendeu que os fatores econômicos e políticos também foram decisivos para as transformações socioculturais, de maneira que ele propõe a divisão do país em dez regiões: o Nordeste agrário, o Mediterrâneo pastoril, a Amazônia e a região extrativa, a Mineração e o planalto, o Centro-oeste extrativista e pastoril, o Extremo sul pastoril, a Colonização estrangeira ${ }^{2}$, o Café, o Cacau e o Sal.

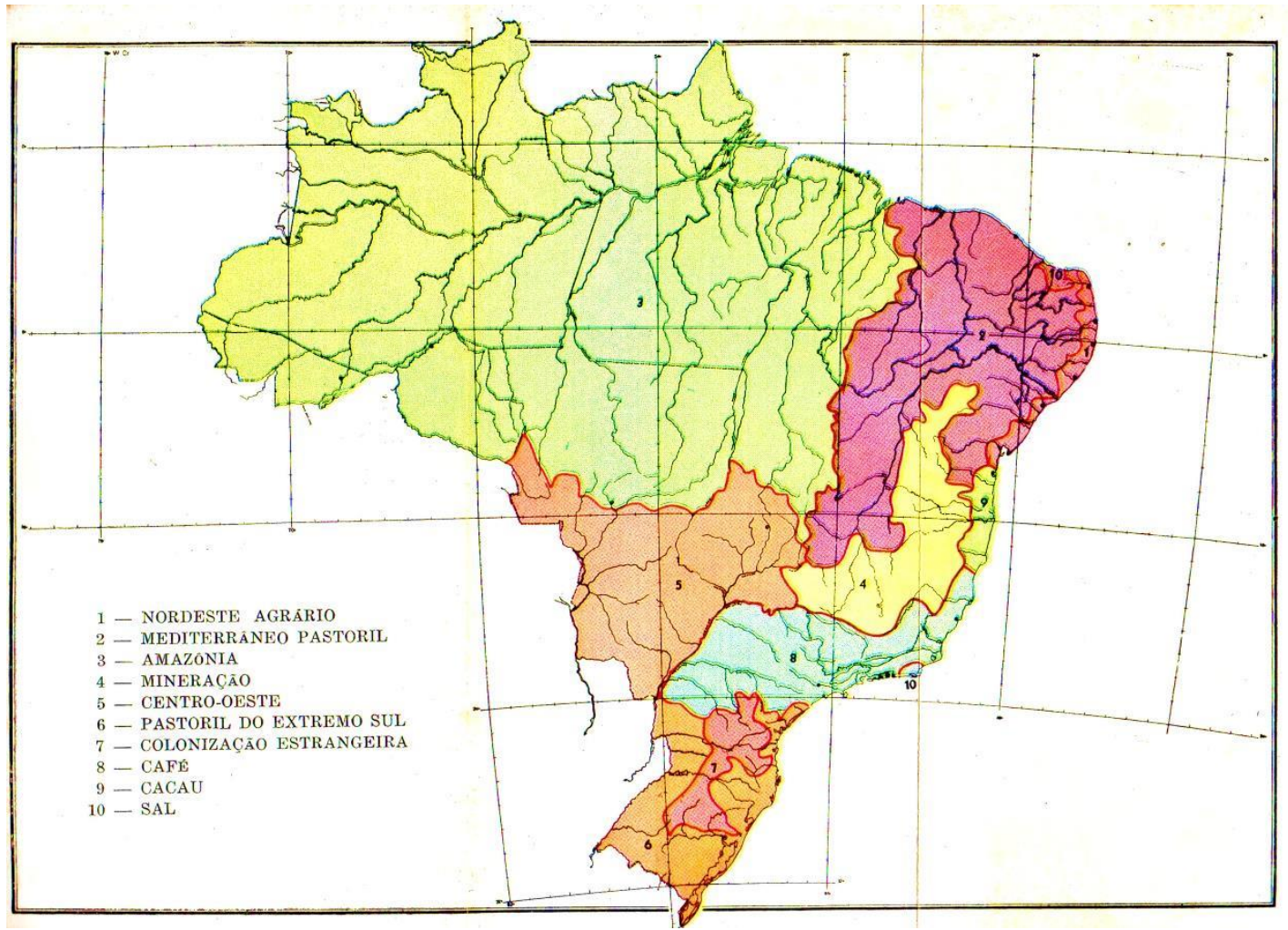

Figura 1: Mapa das regiões propostas por Diégues (1960, p. 473)

Segundo o autor, a imigração de alemães, italianos, poloneses, russos, holandeses e japoneses em áreas não ocupadas por luso-brasileiros contribuíram para a formação de uma nova cultura nas regiões do sul a partir do século XIX. No entanto, observando o mapa, compreende-se que a área predominantemente ocupada pelos estrangeiros é pequena em relação às demais que foram influenciadas pela exploração dos bens de consumo do período, já que de norte a sul há fortemente a influência dos primeiros portugueses em nosso país, sendo eles os responsáveis pela posse das terras e

\footnotetext{
${ }^{2}$ Segundo o autor, a imigração e a colonização estrangeiras "contribuíram para quebrar a unidade, senão mesmo a monotonia, da paisagem cultural de origem lusitana. O quadro cultural de base portuguesa foi enriquecido de outros aspectos; agregaram-se-lhes elementos originários de outras culturas" (1960, p. 351)
} 
expansão das fronteiras. E nisso lembramos que os nossos colonos eram os populares de baixa escolaridade (conforme veremos no capítulo 1). De acordo com Boxer (1963, p.154), "mais de três quintas partes dos viris imigrantes vinham da província do Minho e do Douro", e essa emigração foi impulsionada por fatores socioeconômicos que faziam com que os jovens tivessem de buscar novas oportunidades de vida e ascensão social que não lhes eram oferecidas em seu país de origem (RAMOS, 1993).

De qualquer maneira, embora os colonizadores tenham convivido com africanos e índios, e o Brasil tenha recebido invasões de povos estrangeiros - holandeses em Pernambuco (1630 a 1654); franceses da Paraíba ao Ceará (1579 a 1598) e Maranhão (1594 a 1615); e a imigração no século XIX - , já havia em nosso país um forte superestrato linguístico. Por isso, apesar do primeiro contato com a língua geral dos índios $^{3}$ (RIBEIRO, 1901, p. 22) e a necessidade de comunicação com eles, o português manteve-se como o idioma de prestígio, e, mesmo tendo incorporado vocábulos de origem africana e indígena, conservou-se como principal código de comunicação, de acordo com o que vemos nos documentos coletados no período ${ }^{4}$. Sobre isso, Castilho destaca (2010, p.205) que "os portugueses comandavam os negócios públicos, imprimiam rumos políticos e culturais ao território, predominavam numericamente entre a população branca, tendo por isso um prestígio social maior".

\subsubsection{A importância do bandeirantismo no Brasil}

Como visto, os portugueses que vieram ao Brasil não permaneceram apenas no litoral, porém, das doze capitanias estabelecidas, a principal responsável pela expansão de nossas fronteiras foi a de São Paulo por causa do bandeirantismo promovido pelo povo paulista (HOLANDA, 1976; RIBEIRO, 1901). Os historiadores utilizam esse termo, povo paulista, pois, diferentemente de outras regiões mais abastadas do país, os colonos de São Paulo tiveram de sair em busca de riquezas e até sobrevivência. Dentre eles, escravos e nativos, originou-se uma nova etnia que, em conjunto, foram adentrando nos sertões do país a partir do século XVI, expandindo o território brasileiro para além da determinação do Tratado de Tordesilhas. De acordo com Ribeiro (1901, p. 243),

Da população branca, derramada por entre a dos Índios, originaram-se caribocas e mamelucos, que mais tarde se distinguiram como os mais

\footnotetext{
${ }^{3}$ Segundo Ribeiro, aqui no Brasil viviam "differentes tribus, de sul a norte, com differentes nomes; mas a língua d'ellas era, com poucas differenças, a mesma, d'onde se lhe chamou merecidamente mais tarde a Língua geral".

${ }^{4}$ Ver trabalhos relacionados ao PHPP, in http://phpp.fflch.usp.br/corpus.
} 
audazes pioneiros da terra na organisação das bandeiras, no commercio da escravatura indígena, d'onde resultaram conflictos memoráveis com os jesuítas e horríveis fratricídios pelo descobrimento das minas.

O fato é que a história comprova que os bandeirantes obtiveram sucesso em suas empreitadas, pois, das disputas por novas terras, nos séculos XVII a XVIII, as fronteiras brasileiras expandiram-se, estendendo-se para oeste até os limites com as fronteiras das colônias espanholas, como visto no mapa a seguir:

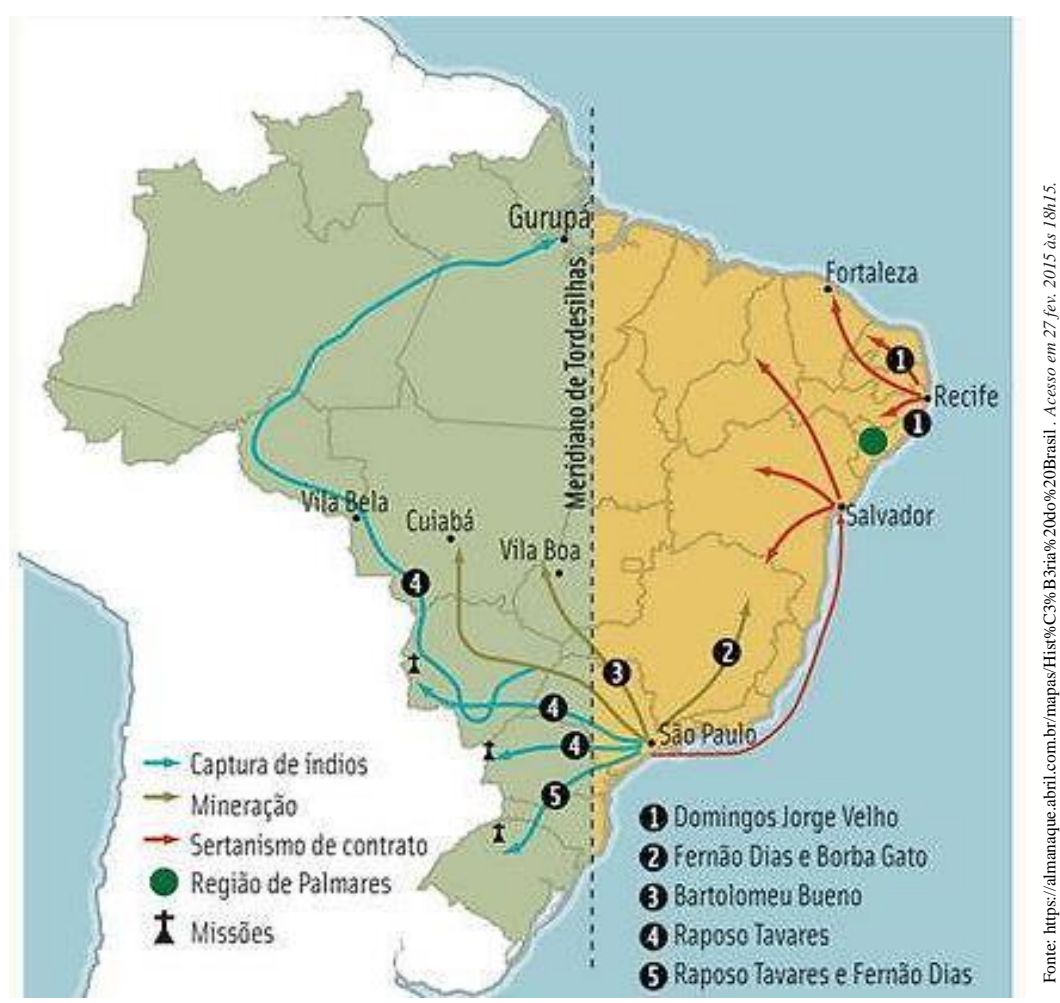

Figura 2: Principais bandeiras realizadas pelo Brasil durante os séculos XVII e XVIII

Consoante Lacombe e Vianna (1974), diversas expedições ocorreram entre os séculos XVI e XVIII com objetivos específicos: o sertanismo de contrato, liderado por Domingos Jorge Velho, foi patrocinado pelo governo-geral para combater índios inimigos, negros aquilombados e facilitar a busca por riquezas minerais na região nordestina. Já as expedições de mineração, organizadas por Fernão Dias, Borba Gato e Bartolomeu Bueno, foram motivadas pela procura de diamantes. E as de Raposo Tavares e Fernão Dias objetivaram a captura de índios para escravização. De modo geral, além de corresponderem aos propósitos a que foram destinados, muitos bandeirantes permaneceram nas localidades desbravadas, favorecendo a formação de novos povoamentos.

Por meio desse processo de expansão, entende-se como ele auxiliou a formação do PB e, possivelmente, foi um dos fatores responsáveis por fazer com que 
determinadas variações linguísticas sejam encontradas em diversas localidades do nosso território brasileiro, já que, como demonstrado, o português foi se espalhando pelo país e se constituía conforme a necessidade da região.

\subsection{Para o estudo do estabelecimento do idioma e suas variantes}

Durante o desenvolvimento desta introdução, comentou-se que nossos colonos eram pessoas com baixo grau de escolaridade, e a língua portuguesa realizada por eles foi levada a diversas regiões. Com isso, as variações linguísticas presentes no DC não apenas poderiam ser encontradas em qualquer lugar, como também entre qualquer meio social, não sendo exclusivas de um determinado grupo. Tal fato é exemplificado - ainda que de maneira cômica - na crônica Quase doutor de Lima Barreto (1915), em que se mostra um estudante de Direito trazendo consigo as variações também apontadas por Amaral: logo no início, o autor transcreve a fala da personagem: "caxero traz aí quarqué cosa de bebê e comê", e finaliza com "Espero tirá a medáia!". Entre os diálogos, o narrador comenta "esse moço foi criado na roça, por isso adquiriu esse modo feio de falar" e, ao final, quando descobre que o personagem está para se formar, revela: "Este homem já tinha passado tantos exames e falava daquela forma e tinha tão firmes conhecimentos!"”.

A data de publicação da crônica mostra-nos que, naquele período, as variações do DC estavam sendo bastante observadas e registradas: não se atentando ao preconceito linguístico, vemos, na crítica do texto de Lima Barreto, a constatação de que tanto as variações quanto o dialeto podiam se revelar em diversos meios, não apenas naqueles desprovidos de educação, como ressaltado por Monteiro Lobato quando criou o seu estereotipado Jeca Tatu em Urupês (1918).

No início do século XX, vivia-se a exaltação da língua portuguesa falada no Brasil por aqueles que a entendiam como nossa identidade nacional, constatação vista com os Modernistas e suas obras durante a Semana de 1922. E, pensando no estado de língua, com a publicação de $O$ dialeto caipira dois anos antes, Amaral juntava-se a esse grupo seleto de escritores: os estudos literários demonstram como Mário de Andrade, Oswald de Andrade e Manuel Bandeira entendiam que a língua portuguesa no Brasil se distinguia em diversos pontos daquela de nossos colonizadores, de maneira que, em $A$ Gramatiquinha de Mário de Andrade (PINTO, 1990), o autor celebra o trabalho de Amaral, utilizando-o como fonte. Mesmo lamentando que ainda não houvesse uma gramática "do brasileiro", Mário de Andrade chama a atenção às variações, destacando 
os registros que Amaral tinha realizado sobre o DC, conforme já mencionado anteriormente.

Quase um século depois, vemos que as constatações do autor continuam a ser matérias de trabalhos científicos, e alguns serão brevemente reunidos aqui para demonstrar que, por ora, esse tema está sendo bem estudado. Por isso, ele poderá ser posto de lado para podermos estudar a entoação do falar caipira, assunto este que necessita de um olhar mais acurado. E, para esse breve levantamento, além dos trabalhos publicados, seguiram-se as anotações de Amaral e parte dos resultados das pesquisas realizadas em ofícios novecentistas da dissertação de Garcia (2009), pois, nesses documentos, também havia o registro de oralidade. Conforme já observado por Vasconcelos (1928), mesmo em textos produzidos por pessoas alfabetizadas, é possível encontrar esses traços. De acordo com Spina (2008, p.289):

Todo esse movimento de ordem doutrinária na sistematização e aprimoramento da língua não impediu que os escritores portugueses dos séculos XVI e XVII mantivessem em sua linguagem as formas arcaicas e populares, e até reproduzissem em algumas de suas obras a linguagem viva e chã de seu tempo.

Embora Spina falasse de um período diferente do atual, sabemos que as reproduções de variantes na linguagem é um processo natural da língua portuguesa. Comecemos citando, como primeiro exemplo, os alçamentos e rebaixamentos de vogais: discutidos desde o século XVI por Fernão de Oliveira ${ }^{5}$ (1975 [1536], p.64), autores como Celso Cunha (1986) compreendem tal fenômeno como conservação brasileira; assim como Matos e Silva (2006) que fez um levantamento utilizando documentos que partiam do século XIII e princípios do XVI, e mostrou-nos a flutuação que havia entre as quatro vogais $-e / i, o / u-$, fossem pré ou pós-tônicas. Ou seja, essa prática não é exclusiva de um certo período, nem é algo contemporâneo.

Nos fólios de Capivari do século XIX e hoje, XXI, por exemplo, tais variações permanecem e são objetos de pesquisa, como visto, nos documentos de 1843 e 1880, os vocábulos veve (vive) e curpo (corpo), respectivamente. Atualmente, há o mesmo evento em Parintins, Tefé, Itacoatiara e Manacapuru, no Amazonas (MARTINS, MAIA, 2010). Em 1883, 1869 e 1883, aparecem nos documentos de Capivari as palavras apicula (apícola) e agricula (agrícola). As realizações também ocorrem do Alto Acre (CHAVES; SANTOS, 2011), Rio Branco/AC (HOSOKAWA, SILVA, 2010) e Rondônia (FRANÇA, 2009). Além delas, nos séculos XIX e XX são vistas variações

\footnotetext{
${ }^{5}$ Segundo o autor: "entre $u$ e $o$ pequeno há tanta vizinhança, que quase nos confundimos, dizendo uns somir e outros sumir e dormir ou durmir, bolir ou bulir. E outro tanto entre $i$ e $e$ pequeno, como memória ou memórea, glória ou glórea".
} 
bastante recorrentes hoje, como descubrir (descobrir) em 1785, 1821 e 1843; filis (feliz), em 1841; e pustura (postura), em 1854; discidirem (decidirem) em 1841; intupido (entupido) em 1835; insignar (ensinar) em 1846; prizidente (presidente) em 1829 e 1833; imprego (emprego) em 1829 e 1844. Tais variações estão em Bragança, no Pará (FREITAS, 2001); em Planalto, na Bahia (MATOS et alii, 2007), Rio Branco, no Acre (HOSOKAWA; SILVA, 2010), em Mocajuba, no Pará (CAMPOS, 2008); e Nova Venécia, no Espírito Santo (GIANNI FONTIS, 2004).

Outro fato é o registro de termos como fragante (flagrante) anotado em 1836; vurgarizei (vulgarizei) em 1854; poiar (poial) em 1854; e dificurdade (dificuldade) em 1865. Esses exemplos de alternância entre $/ \mathrm{r} / \mathrm{e} / \mathrm{l} /{ }^{6}$, como curpa (culpa), arma ou aurma (alma) são encontrados em todo o Brasil (COSTA, 2006; FREITAG et alii, 2010; CASTILHO, 2010), também no Baixo-Minho (SEQUEIRA, 1957), Braga (VASCONCELOS, 1928) e no dialeto barranquenho, Concelho de Barranco, fronteira entre Portugal e Espanha (VASCONCELOS, 1985). Vasconcelos (1928, p.326) acentua a presença desse processo no estudo da linguagem de Gil Vicente referente ao século XV/XVI.

Spina (2008, p. 209) também analisa o uso, no XVI, de palavras como tromento, faldra e perceito (tormento, fralda, preceito). No século XIX, vemos a manutenção da variante em preseguiçoes (perseguições), em 1864; e pertençã̃ (pretensão) em 1877. Além disso, a palavra drento, por exemplo, considerada variante linguística no Brasil, é encontrada no léxico mirandês e na zona transmontana portuguesa, de Macedo de Cavaleiro a Miranda (VASCONCELOS, 1985). Da Hora et alii (2007, p.187) fez um levantamento linguístico da recorrência dessa variante no nordeste de nosso país, e os resultados seguem abaixo:

a) Século XVII:

TELLES, Henrique Moniz. Carta de Henrique Moniz Telles, escrita na Bahia de Todos os Santos, em 5 de Junho de 1638. In Galindo, Marcos (Org.) Cartas da Bahia. Introdução e notas de Pablo Antonio Iglesias Magalhães. Manuscrito do Fundo Geral da Biblioteca de Lisboa, número 1555, folhas 292 a 298. Recife: Nectar, no prelo.

b) Séculos XVIII e XIX:

FONSECA, Maria Cristina de A. P. Caracterização linguística de cartas oficiais da Paraíba dos séculos XVIII e XIX. João Pessoa, 2003. c) Século XIX:

OLIVEIRA, Klebson. Negros e escrita no Brasil do século XIX. Salvador: UFBA, 2006.

\footnotetext{
6 Também chamado de rotacismo por autores contemporâneos (COX; ASSAD, 1999; BORTONIRICARDO, 2004; BAGNO, 2007; SANTANA et alii, 2008), Bueno (1967, p.228) não admite o uso do termo, informando que tal nomenclatura é dada apenas pela troca do $s$ por $r$ intervocálico. Dubois et alii (2001, p. 523), todavia, informa que, por extensão, rotacismo também designa a transformação do [r] a partir de outras consoantes, como [d] e sobretudo [1].
} 
d) Séculos XX/XXI: - Dados de fala espontânea:

HORA, Dermeval. Projeto Variação Linguística no Estado da Paraíba, 1993.

TELLES, Stella. Corpus do Português Falado no Estado de Pernambuco, 2005. Projeto Variação Linguística Urbana no Sul do País, VARSUL, 1989.

Outro processo encontrado nos séculos passados, e que ainda se ouve nas regiões de Capivari, é a epêntese de consoante /r/, sendo comum ouvir nas ruas e comércios variações como largartixa e cardarço. Spina (2008, p.298) anota no XVI casos como almorço (almoço). Nos documentos da cidade, apresentaram-se formentar (fomentar) em 1882, e hyportese (hipótese) em 1884.

Tanto no século XVIII quanto no XIX, verifica-se a dissimilação em propio (próprio) em 1785 e impropio (improprio) em 1841, entre outras. O mesmo vocábulo é encontrado no espanhol. Segundo Paiva (2008, p. 171) "o bilinguismo predominou dos meados do século XV à primeira metade do século XVII", entretanto, Teyssier (1959, p.293) afirma que "a intromissão deste no português praticamente inexiste". De qualquer maneira, tais variantes sempre estiveram na língua, dado que Nunes (1989) traz os mesmos exemplos datando o período anterior ao século XVI.

Sobre a apócope de /1/ e /r/, Mendonça (1936) afirma que a sua queda, bem como a vocalização de /1/, também ocorria na fala das populações luso-africanas das ilhas de Cabo Verde, São Tomé, Príncipe e Ano Bom. E Vasconcelos (1987, p.98) apresenta a apócope do /r/ no Norte, no centro e no sul de Portugal. Em um documento de Capivari do século XIX, há a ocorrência de regula (regular) - do contexto "a produção regula do café [...]" - e existem diversas outras executadas pelos falantes do XXI.

Em relação à síncope, Spina (2008, p.293) registra o uso de exprimentar e esprito (experimentar, espírito) no XVI. No XIX, tal fenômeno mantém-se em fragante (flagrante) em 1836; detriorado (deteriorado) em 1852 e 1858; priudo (periodo) em 1864; e cadavres (cadaveres) em $1851^{7}$. No estudo de Araujo et alii (2008), também há a menção da variante tratada nos dias atuais cuja incidência se dá em paroxítonas e proparoxítonas. Sob análise fonética/fonológica, Bisol (2000, p. 406) complementa:

[...] como a regra de redução continua ativa na sincronia do português brasileiro, assim como a síncope em dialetos populares [...] permite afirmar que o domínio da regra de redução da átona não-final, por

\footnotetext{
${ }^{7}$ Embora no francês exista o vocábulo cadavre, deduziu-se, devido à grande quantidade de variantes presentes no fólio, que o autor transcreveu a palavra da forma como falava e não tinha contato com a língua estrangeira, visto que era de família popular e, em Capivari, não houve imigração de franceses.
} 
neutralização designada desde Câmara Júnior, é o pé métrico, definido como um pé dissílabo de cabeça à esquerda.

A epêntese, por sua vez, é apontada em abissoluto, obiter, indiguinado e busucar (absoluto, obter, indignado, buscar) por Spina (2008, p.299) no XVI como "fenômeno vigente até os nossos dias", estando presente na região setentrional portuguesa (VASCONCELOS, 1928) e em diversas regiões brasileiras, como o Rio de Janeiro (NASCENTES, 1953). No XIX, foram encontrados digueno (digno) em 1865; adimirar (admirar) em 1886; e perezidente (presidente) em 1855.

Quanto ao glide, segundo Noll (2008) e Viaro (2006), trata-se de inovação do português brasileiro, e tal processo foi encontrado em um único exemplo de um fólio de 1854 com o vocábulo féis (fez). No século XXI, no entanto, é largamente encontrado com nóis, portugueis, rapaiz e vocêis (nós, português, rapaz, vocês) ${ }^{8}$.

Mais um item verificado foi a redução de ditongos em vocábulos como baxo, bejar, otono (baixo, beijar, outono) e a ditongação de cereija, ouliveira, oulhar (cereja, oliveira, olhar), observados também por Sequeira (1957) no Baixo-Minho, e Gil Vicente (VASCONCELOS, 1928) no século XVI. No XIX, nos documentos de Capivari, foi visto collejo (collegio) em 1884; duradoras (duradouras) em 1841; capoiens (capões) em 1841; e feixar (fechar) em 1835. Tal processo ocorre em Vitória da Conquista na Bahia (SANTOS; et alii, 2007), Fortaleza no Ceará (ARAGÃO, 2009), e Manauara no Amazonas (BABILÔNIA BRANDÃO, s/d). Além de apresentar-se no sul (BATTISTI, 2002), a ditongação também ocorre em Altamira, no Pará (LOPES, 2002), e em Caxias, no Maranhão (SANTO ORCERO, 2002).

Outro processo comum é a deslateralização de $/ K /$. Spina (2008, p. 299) traz a "vocalização do grupo lh: muyere, por mulher; [...] oyo por olho; mioro por melhor" justificando que "inúmeras modificações fonéticas, operadas no português dos séculos XVI e XVII, curiosamente poderão até ser explicadas pela influência simultânea da língua tupi e dos falares trazidos pelos escravos africanos". No entanto, Noll (2008, p. 241), utilizando o Atlas lingüístico de La Península Ibérica, informa a deslateralização em Trás-os-Montes, afirmando assim que "retroceder o fenômeno à influência do tupiguarani ou das línguas africanas não é, portanto, provável”.

Na documentação de Capivari, tais variantes não foram encontradas, entretanto, há a presença na fala dos entrevistados do Médio Tietê, sendo comum apresentarem os

\footnotetext{
${ }^{8}$ Dentro do internetês, o último exemplo é visto sob a codificação $v 6$, ou seja, a abreviação de vo com a sonoridade do número seis, o que demonstra como tal prática é usada inclusive em outras localizações e no meio virtual - base atual que mais traz variações escritas da linguagem oral.
} 
vocábulos trabaia, óia, veiarada e véio (trabalha, olha, velharada, velho) durante o diálogo (GARCIA, 2009). No espanhol, tal fenômeno é chamado de yeísmo.

Quanto à desnasalização das vogais átonas em posição final, Vasconcelos (1928) registra os termos home, corage e as formas verbais entre Douro e Minho. Teyssier (1983, p. 607) também encontra exemplares semelhantes em textos teatrais do século XVIII. Da mesma forma, tal processo é aparente nos documentos do XIX, com exemplos como contaje (contagem) em 1834, e parage (paragem) em 1808; e Oliveira (2008) vê o mesmo evento ocorrendo em documentos também oitocentistas de Salvador, Bahia, desta vez por escritores africanos.

Para finalizar, a vocalização de /l/ é vista desde o século XIX em que são encontrados vestígios no dialeto caipira: em 1808, achou-se oltogaram (outorgaram) e em 1842, quintão (quintal). Noll (2008, p. 239) afirma que

A vocalização do /l/ implosivo no português brasileiro é um processo que ocorreu de forma ampla nas línguas românicas (cf. Kolovrat, 1923). Trata-se de um desenvolvimento da velarização do /l/ implosivo, já atestada no latim pré-clássico. Desse modo, o francês, o espanhol e o português, por exemplo, modificaram o latim altru $(m)$ respectivamente para autre, outro, outro, enquanto o catalão conservou o /1/ velarizado em altre.

\subsection{Variações do caipira e do Brasil}

De acordo com as observações feitas, apoia-se a tese de que o português brasileiro seja uma continuação do arcaico ${ }^{9}$, tendo como base as comparações dos trabalhos: de Spina, no XVI e XVII, abrangendo as variações do idioma no período em que o Brasil estava sendo colonizado; de Vasconcelos e seus estudos dialetais do Norte de Portugal; e dos demais pesquisadores de suma importância, perpassando por entre os séculos, confirmando a manutenção. Partindo do método histórico-comparativo e unindo ao da geografia linguística ${ }^{10}$, podemos cruzar dados para verificar a existência

\footnotetext{
9 Em Nova Gramática do Português Brasileiro, Castilho levanta algumas teses sobre a formação do português brasileiro, dentre elas, a de que a língua seria uma continuação do arcaico (2010, p. 189): "outros linguistas sustentam que as línguas naturais mudam continuamente com o tempo, obedecendo porém as linhas de forças desenhadas por sua própria estrutura. [...] De acordo com este ponto de vista, o PB resulta de uma mudança natural, explicada por tendências evolutivas que tinham começado já na península ibérica, e com isso poderíamos dizer que o PB é uma continuação do português arcaico".

${ }^{10}$ Segundo Bassetto (2002, p. 64 e 70), o método histórico-comparativo vale-se de "dados colhidos nas línguas com a mesma origem [que] são comparados entre si para se lhes encontrar a forma originária, determinar os metaplasmos ocorridos, verificar-lhes o significado, a formação de novos campos semânticos, o motivo ou os motivos de tais formações, e inúmeras questões semelhantes" enquanto a geografia linguística "se ocupa com a situação em que uma língua se encontra num determinado momento, em localidades ou regiões previamente escolhidas”.
} 
dessas variantes, de modo a constatar que existe ainda a manutenção de determinados fenômenos em diversas regiões díspares.

Sabe-se que as proporções territoriais brasileiras são continentais, e que a colonização não se deu de maneira uniforme: conforme Ribeiro (1901), no século XVI houve focos de colonização, isto é, grupos vieram para São Paulo, Pernambuco, Salvador, Maranhão e Rio de Janeiro, e trabalharam cada qual em suas capitanias de maneira particular. Isso significa que esses grupos - que, posteriormente, tornaram-se os paulistas e nordestinos, por exemplo - ficaram em regiões distintas. Algumas dessas localidades mantiveram-se mais isoladas, como as do interior paulista, enquanto outras, por terem mais importância política como a Rio de Janeiro, recebiam com mais constância influências externas. Esses fatos elucidam o motivo de haver a diversidade linguística ao mesmo tempo em que há variantes coincidentes em todo o país. O método neolinguístico ou espacial de Matteo Bartoli (1945, apud BASSETTO, 2002, p. 79-81) explica que:

1. Havendo palavras diferentes em fases cronológicas distintas para um significado, a forma da área mais afastada ou de acesso difícil costuma ser a mais antiga. [...]

2. De acordo com esta segunda "norma de área", as formas de regiões periféricas são mais antigas que as correspondentes centrais. [...]

3. São mais antigas as palavras conservadas em áreas mais amplas que as correspondentes encontradas em áreas mais restritas. [...]

4. Regiões de latinização mais tardia costumam conservar formas mais antigas, sobretudo em relação à Itália; isso quer dizer que o latim da Itália era mais inovador que o do Império em geral. [...]

5. Palavras desaparecidas, arcaizadas ou menos usuais costumam ser as mais antigas. [...]

Ou seja, embora tenha sido desenvolvido para o estudo de línguas românicas, o método de Bartoli pode ser aplicável no PB, tendo em vista os diversos registros de variantes e conservações, como o processo de abaixamento de vogal tônica visto em vocábulos como veve (vive) - que tem sua ocorrência registrada em Capivari (1880) e ainda é corrente em outras localidades, como no Mato Grosso do Sul.

Por fim, esses traços semelhantes esclarecem o motivo de não ser possível estabelecer limites linguísticos coincidindo com os geográficos e administrativos (CALLOU; LEITE, 2002). E, por isso tudo, entende-se que a prosódia da língua também pode resguardar marcas dialetais, sendo necessária a análise entoacional do DC. 


\title{
2. O estudo da entoação caipira
}

No capítulo Fonética da obra de Amaral (1920), vemos que o autor considera a prosódia como "o ritmo e musicalidade da linguagem", e faz algumas considerações acerca do DC. Porém, o próprio termo desencadeou, nas últimas décadas, diversos estudos para que se pudesse estabelecer realmente como deve ser interpretado. Em 2000, Di Cristo o definiu como um ramo da linguística destinado à descrição e representação dos elementos da expressão oral, associando-o às variações de parâmetros físicos, como a frequência $\mathrm{f}_{0}$, duração e intensidade. Dentro dessa linha de pensamento, conforme Consoni (2010, p. 9), os termos prosódia e entoação não devem ser confundidos, tendo em vista que aquele "pode assumir definições diversas, ele pode estar ligado exclusivamente a variações de frequência fundamental ou incluir variações de outros parâmetros prosódicos, tais como duração e intensidade".

Assim, esta tese segue a linha teórica proposta por Ferreira Netto (2008) em que defende a entoação como sequência de tons, iguais ou diferentes, produzidos pela voz durante a fala, podendo ser decomposta em componentes estruturadoras e semânticofuncionais da entoação da fala: finalização $(F)$ e sustentação $(S)$, foco/ênfase $(E)$ e acento lexical (A). De acordo com o autor:

\begin{abstract}
A sustentação é consequência do esforço que se acrescenta a cada um dos momentos da fala, incluindo-se o inicial, para compensar a declinação pontual de finalização. Ritmo tonal é consequência da ação dessas duas tendências que atuam em sentidos opostos, possibilitando a produção da fala. A componente $\mathrm{F}$ associa-se ao fato de que se trata do tom-alvo da declinação pontual, estabelecida por um intervalo ideal decrescente de 7 st do tom médio (TM) obtido até o momento $\mathrm{Zt}$ (FERREIRA NETTO; CONSONI, 2008). O tom médio é a tendência central dos valores válidos de $\mathrm{f}_{0}$ calculada como a média aritmética acumulada no tempo. Os valores válidos mensurados são os momentos de $f_{0}$ que cumprem as restrições de altura, intensidade e duração. $(2008$, p.2)
\end{abstract}

Segundo ele, a partir do TM têm-se as formas prototípicas fixas de variação tonal atuando como atratores para ocorrências próximas, sendo responsáveis por ações que refletem as intenções informativas do falante. Essas intenções estão ligadas às emoções transmitidas na fala (SCHERER, 1986; MURRAY; ARNOTT, 1993).

Conforme descrito no capítulo 2, a análise da entoação é produzida pelo ExProsodia (FERREIRA-NETTO, 2010), que faz a análise automática de arquivos sonoros digitais, promovendo o estudo de séries temporais como fenômenos prosódicos simultâneos não-hierarquizados na língua. Deste modo, o aplicativo decompõe os dados conforme explicitado anteriormente, e, por meio deles, utilizam-se análises estatísticas geradas pelo programa Microsoft Excel 2010 e KyPlot 20.0 beta para chegarmos às 
conclusões acerca da entoação caipira, as quais veremos nas Considerações Finais desta tese.

\section{Concentração do estudo: informantes das cidades do Médio Tietê e do norte de Portugal}

As cidades estudadas no Médio Tietê foram Capivari, Porto Feliz, Itu, Piracicaba, Santana de Parnaíba, Tietê e Pirapora do Bom Jesus; e, no norte de Portugal, Braga, Bragança e Vila Real. As cidades brasileiras foram escolhidas por serem, primeiramente, o campo de estudo de Amaral, segundo nos informa Duarte (1955, p. 26): "restringindo-se até então às zonas de Capivari, Piracicaba, Tietê, Itu, Sorocaba e São Carlos, onde fez observações e de onde se originavam muitos dos seus informantes"; e por serem o caminho das bandeiras e das monções que seguiram a linha do rio Tietê entre os séculos XVI a XVIII (HOLANDA, 1976), localidades que mantiveram características próprias, por vezes heranças dos primeiros povoadores e com pouca influência externa, como observam os estudos de Candido (1975) e Ribeiro (2002) particularizando as comunidades dos caipiras paulistas.

Depois de realizados os estudos preliminares com a metodologia desenvolvida no capítulo 3, o DC apresentou resultados coincidentes com as pesquisas já realizadas por Baz e Costa (ambas de 2011): em suas teses, as pesquisadoras identificaram o traço plagal nas falas dos índios do Paraguai e do Mato Grosso do Sul, respectivamente, algo que também ocorreu com os dados fornecidos pelos informantes do Médio Tietê. Logo, levantou-se a hipótese de que, talvez, esse traço fosse influência indígena no DC; e para se comprovar a provável influência, foi necessário estudar os falares de portugueses. Desta forma, a pesquisa estendeu-se até as cidades da região do Minho e Trás-osMontes, por serem as localidades originárias do período da Reconquista e da Formação de Portugal, e, segundo João de Barros (1785, p. 225), as conservadoras da "semente portuguesa".

Nas cidades brasileiras e portuguesas, ao todo foram selecionados 40 (quarenta) informantes, sendo 20 homens e 20 mulheres, todos com idade acima de sessenta anos, brasileiros e portugueses natos e de baixa escolaridade.

Sem utilização de questionários prontos, as entrevistas abertas foram conduzidas por meio de perguntas comuns a todos da comunidade, buscando histórias de seu passado. Optou-se pelas falas espontâneas, pois, segundo Chacon (1998) e Pacheco (2006), a leitura e falas monitoradas podem fazer com que o interlocutor modifique sua entoação. Sobre o assunto, Ferreira-Netto e Consoni (2008, p. 521), em seu trabalho 
Estratégias prosódicas da leitura em voz alta e da fala espontânea, verificam que "o leitor tem de, necessariamente, criar a prosódia para o texto, a partir de suas hipóteses, [...], enquanto que a prosódia da fala espontânea flui automaticamente, sem a interferência consciente do falante".

Assim sendo, os informantes foram questionados sobre a infância, juventude, namoros, lembranças de como eram as cidades antes da chegada da energia elétrica, entre outros, de modo que suas respostas fossem parecidas e gerassem material semelhante para a análise prosódica. Segundo Ferreira Netto (1991, p.131), na "uniformidade de opiniões, reconhece-se a existência da covariação linguística e social e consequentemente diferenciação da língua em códigos diversos".

De modo a estabelecer um elemento comparativo, gravações a partir de programas jornalísticos da cidade de São Paulo foram coletadas, porque "se trata de uma linguagem falada, mas marcadamente orientada pelos padrões da língua escrita" (ARAÚJO, 2003, p. 59), cuja descrição será vista no capítulo 2. Além disso, como já explicado, também é um elemento comparativo os falares dos portugueses do Norte de Portugal.

\section{Apresentação da tese}

Esta tese está dividida em três capítulos que visam não apenas explicar procedimentos e o resultado do exame da entoação do DC, mas também trazer subsídios para a continuidade dos estudos sobre o dialeto paulista que estão sendo desenvolvidos pelo PHPP.

Por isso, começamos a detalhar as regiões do Médio Tietê e Portugal com maior acuidade no capítulo 1, em que se apresentarão as cidades e o motivo de estudá-las. Tendo em vista os comentários realizados nesta introdução sobre a importância de se conhecer a história do local para entendermos seu estado de língua, esse primeiro capítulo trará informações particularizadas acerca da criação dessas localidades, o que elas têm ou não em comum, entre outros aspectos, de modo a compreendermos o que isso pode implicar na produção da prosódia e, até mesmo, nos processos dialetais.

No segundo capítulo, há a descrição de cada informante e da metodologia utilizada para a formação da pesquisa. De modo geral, esse capítulo tende a ser extremamente didático, pois, além das descrições, houve a preocupação de se registrar variadas informações, dos locais e das pessoas, levantadas durante a pesquisa de campo, de modo a humanizar o fazer científico e auxiliar outros pesquisadores durante a condução de suas pesquisas. Percebemos, assim, que o trato humano, quando nos 
referimos ao exame da linguagem, é fundamental para que a coleta capte o dialeto em sua forma mais natural.

Ainda nesse capítulo, a preocupação didática permanece para que haja explicação plena do processo de análise sistematizada desenvolvida pelo Projeto ExProsodia e dos conceitos de entoação e finalizações. Embora nesta introdução a teoria tenha sido previamente apresentada, ela será devidamente explanada, de forma que quaisquer pesquisadores de variadas áreas possam compreender a importância e realização do trabalho sistematizado que confere verossimilitude à pesquisa.

No terceiro, trar-se-á a análise dos dados entre o dialeto caipira e o falar neutro, e o exame dos falantes do norte de Portugal em comparação ao DC. Demonstrados em tabelas e gráficos, os resultados serão discutidos e explicados para a compreensão de como ocorrem os tons médios e finais das regiões destacadas. Os resultados dessas análises demonstram que o dialeto caipira traz evidências plagais, assim como as falas dos índios paraguaios (BAZ, 2011) e os índios guatós (COSTA, 2011). Tais evidências acabam por introduzirem outro estudo: de como a escolarização é fator fundamental para a execução da entoação na prosódia. Desses fatos, geram-se as discussões que serão trabalhadas nas Considerações Finais, confirmando as diferenças entoacionais entre o dialeto caipira e o padrão, e trazendo-lhe mais uma caracterização até então desconhecida. 


\section{CAPÍTULO 1 \\ As cidades do Médio Tietê, do Norte de Portugal e a cultura caipira}




\section{As cidades do Médio Tietê, do Norte de Portugal e a cultura caipira}

É de conhecimento que o estabelecimento de uma língua está intimamente ligado à sua história. Por isso, estudaram-se as cidades: suas fundações, suas influências, entre outras informações, para notarem-se, por meio de coincidências e diferenças, os traços comuns, ou não, das falas; já que "a história dos diversos aspectos da língua deixa seus traços no espaço" (BASSETTO, 2001, p.78).

Desta maneira, para a constituição desta tese, inicialmente buscaram-se as cidades do Médio Tietê por terem sido criadas a partir das entradas bandeirantes, que aproveitavam a bacia hidrográfica da região para adentrarem no sertão paulista; e por serem localidades pesquisadas por Amaral para o seu livro $O$ dialeto caipira (1920). Sendo assim, os informantes foram selecionados em Santana de Parnaíba, Pirapora do Bom Jesus, Itu, Tietê, Porto Feliz, Capivari e Piracicaba; urbes escolhidas e observadas pelo PHPP, mais especificamente pelo subprojeto Formação e expansão do português paulista ao longo do rio Tietê até Mato-Grosso a partir do século XVI, ao qual damos continuidade. Mas, agora, pela necessidade de responder a mais perguntas acerca do dialeto e sua entoação, incluíram-se os estudos de prosódia pelo Projeto ExProsodia, coordenado pelo Prof. Dr. Waldemar Ferreira Netto.
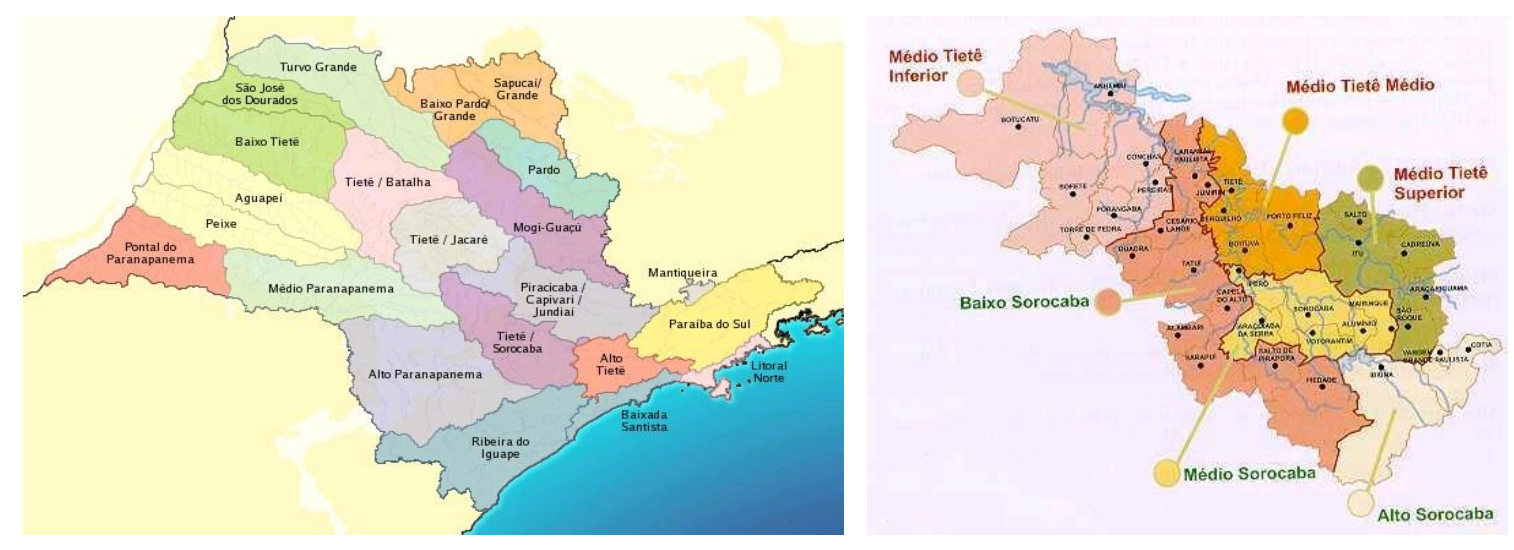

Figura 3: à esquerda, divisões das bacias hidrográficas do Estado de São Paulo; à direita, destaque para as regiões do Médio Tietê.

Cidades do Médio Tietê foram eleitas, pois, segundo Antônio Candido (1975), o processo de expansão do interior paulista fez com que essas regiões por onde passaram os bandeirantes obtivessem algumas características próprias e, até mesmo independentes das demais localidades em que houve interesses distintos de colonização daqueles que viviam no planalto de São Paulo. De acordo com o autor (1975, p.35), 
Da expansão geográfica dos paulistas, nos séculos XVI, XVII e XVIII, resultou não apenas incorporação de território às terras da Coroa portuguesa na América, mas a definição de certos tipos de cultura e vida social, condicionados em grande parte por aquele fenômeno de mobilidade. [...] Basta analisar que em certas porções do grande território devassado pelas bandeiras e entradas - já denominado significativamente Paulistânia - as características iniciais do vicentino se desdobraram numa variedade subcultural do tronco português, que se pode chamar de cultura caipira.

Nesse trecho, observamos que Candido compreendia que a cultura caipira particularizou-se, tornando-se derivada daquela de Portugal. Por causa disso, gerou-se a dúvida: qual seria atualmente a influência entoacional do português trazido por nossos colonizadores sobre o DC?

Para complementar essa incerteza que teve início nos estudos geográficohistóricos, os primeiros resultados das análises sobre entoação levantaram algumas hipóteses que envolviam tanto a interferência da língua indígena no DC, quanto a conservação do português europeu. Destarte, foi necessário expandir a pesquisa para algumas cidades de Portugal.

As localidades escolhidas foram Braga, Bragança e Vila Real, ao norte do país. O motivo da escolha deve-se a:

1. questões históricas: a partir do século XII, o movimento da Reconquista, ou Conquista Cristã, iniciou-se no norte do país, partindo da Galiza para o sul (HERCULANO, 1863);

2. variantes linguísticas: as regiões de Minho e Douro possuem diversas variações coincidentes com as do DC do Médio Tietê, conforme levantado por autores como Vasconcelos (1928; 1985) e Sequeira (1957);

3. alta taxa de emigração para o Brasil de pessoas analfabetas: mesmo não havendo registros sobre taxa de analfabetismo nos séculos XVI a XVII, conjectura-se que esta tenha sido elevada, tendo em vista os números apresentados a partir do século XVIII, em que consta que até o ano de 1878, 79,4\% dos portugueses não sabiam ler (RAMOS, 1988, p. 1067). O grande número de emigrantes da região em conjunto com a taxa de analfabetismo são informações determinantes para gerirmos algumas conclusões sobre a entoação do DC, consoante será visto nos capítulos 3 e 4 . 

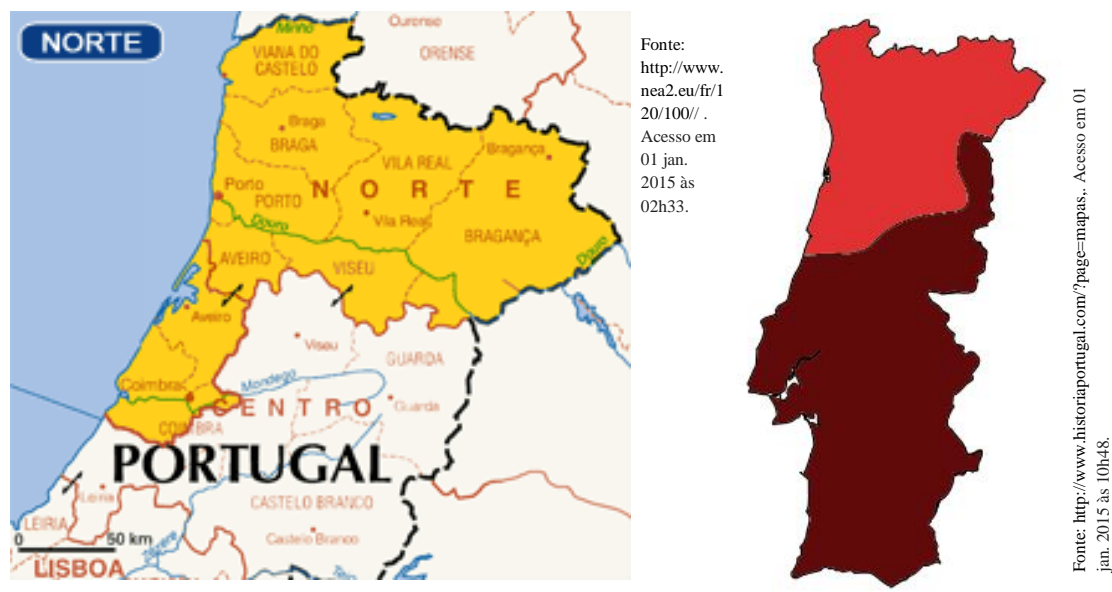

Figura 4: à direita, localização das cidades de Braga, Vila Real e Bragança no mapa de Portugal. À esquerda, a área mais clara é a retomada do Condado Portucalense em 1128. Neste ano, Afonso Henrique derrota a sua mãe na Batalha de S. Mamede, e, em 1139, torna-se rei e consolida a autonomia de Portugal, alargando para o sul os limites da Reconquista (HERCULANO, 1863)

Sendo assim, as entrevistas dos portugueses dessa região foram utilizadas como elementos de comparação entre as do Médio Tietê, conforme veremos com mais acuidade ao decorrer da tese.

\section{O surgimento das cidades do Médio Tietê}

De modo geral, os povoados que originariam as cidades ora citadas surgiram mais ou menos da mesma forma durante os séculos XVII/XVIII devido às necessidades colonizadoras, e constituíram-se como vilas entre os séculos XVIII e XIX. De acordo com Holanda (1995, p. 101-102), o processo de ocupação do interior deu-se por causa de os moradores de São Paulo terem "pouco contato com Portugal e de muita mestiçagem com forasteiros e indígenas". Desta forma, a expansão paulista não tinha motivação portuguesa e foi impulsionada pela falta de recurso, como menciona o autor (1975, p. 20): “distanciados dos centros de consumo, incapacitados, por isso, de importar em apreciável escala os negros africanos, eles deverão contentar-se com o braço indígena - os negros da terra -; para obtê-lo é que são forçados a correr sertões inóspitos e ignorados".

Destarte, das viagens bandeirantes nascem as primeiras paragens, que eram locais por onde os viajantes podiam ficar para ter um pouco de descanso e algumas facilidades antes de seguirem sua rota. Em Holanda (1995, p.21) vê-se que "os índios se utilizassem continuamente de determinados caminhos e até mesmo que os adaptassem às necessidades de um trânsito frequente" e nesses locais se situaram "pousos reúnos, de onde sairiam depois alguns povoados prósperos".

Com o estabelecimento das monções, as paragens acumulavam mais moradores que se beneficiavam das vendas de canoas e comércio em geral, trazendo segurança aos 
viajantes, pois, segundo o autor (1995, p.28), “a presença de um núcleo de povoadores permanentemente instalados no lugar diminuía, além disso, os azares de uma empresa muitas vezes arriscada e nem sempre compensadora".

A partir do século XVIII, houve a necessidade de ocupação mais efetiva do Oeste e do Sudoeste do país, pois o descobrimento de minas obrigou "Portugal a pôr um pouco mais de ordem em sua colônia" (HOLANDA, 1995, p.103). Deste modo, ainda segundo o autor (1975, p.41), a administração colonial teve "por objetivo converter o Tietê em uma verdadeira linha estratégica para a ocupação" das citadas regiões, cedendo sesmarias "nas bordas do Tietê a quem pedisse. Ao mesmo tempo, enviava a Antônio Correia Barbosa uma primeira leva de vagabundos, a fim de serem fixados da melhor forma possível pelas margens do rio".

Com a escassez de ouro e pedras preciosas, foi preciso dar um novo desígnio para toda a extensão do rio Tietê. Assim, o Capitão General Antônio Manuel de Melo Castro e Mendonça promoveu o povoamento para "socorrer os viajantes que se destinassem a Cuiabá e Mato Grosso [para] facilitar as diligências do Real Serviço e promover a pronta e eficaz comunicação com as fronteiras 'quando se restabelecessem em segurança do Estado"” (1975, p.43).

Nos fins do século XVIII e início do XIX, a agricultura de subsistência deu lugar à de exploração com a expansão da economia agrícola no estado de São Paulo. Os povoamentos tiveram um novo princípio e muitos se esmeraram na produção de açúcar e café (DOLHNIKOFF, 2005, p.24).

\subsection{Santana de Parnaíba}

O povoado de Parnaíba começa a existir a partir de uma bandeira efetuada próximo à Vila de São Paulo de Paratininga, em que houve a necessidade de defender a citada região dos assaltos de tribos indígenas. Assim, um bandeirante, Manoel Fernandes Ramos, se estabeleceu na localidade em 1560, e, em 1580, surge a fazenda chamada Parnaíba e a construção da capela de Santa Ana (Sant'Ana), solicitada por Suzana Dias, esposa mameluca do bandeirante e neta do Cacique Tibiriçá (um dos responsáveis por auxiliar os bandeirantes para a expansão das terras brasileiras). $\mathrm{O}$ casal,

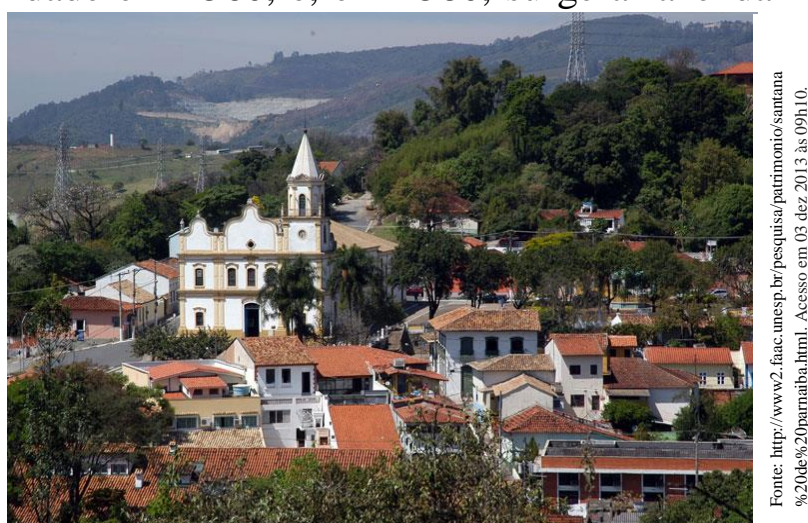

Figura 5: vista do centro histórico 
de importância política, cedeu sesmarias - que depois se tornariam as cidades de São Roque, Araçariguama, Itu e Sorocaba -, o que ajudou a desenvolver a localidade com o cultivo de produtos agrícolas e até na atividade de mineração, entre 1591 a 1601 (MOTA, 2007, p.19).

Pertencente à Vila de São Paulo, conforme Mota (2007, p.24), Santana de Parnaíba obteve o status de vila em 1625 e servia como núcleo de abastecimento de grandes bandeiras, além de receber benefícios dos próprios viajantes, que retornavam com animais, ouro e demais riquezas das regiões exploradas. Na segunda metade do século XVIII, a cidade entrou em decadência devido ao desaparecimento das monções e do declínio da capitania de São Paulo (MOTA, 2007, p.32). No XIX, Santana de Parnaíba, por não ser beneficiada pelos meios de transportes que então surgiam (as linhas férreas não passavam por lá), teve um declínio demográfico, pois seus habitantes se mudaram em busca de novas oportunidades. No final do século, a empresa hidroelétrica São Paulo Light \& Power Co. estabeleceu-se na cidade, porém, esta se manteve com a economia agrícola. Sem grandes evoluções, somente no século XX, com a construção das rodovias SP-312, Anhanguera e Castelo Branco, Santana de Parnaíba voltou a ter crescimento demográfico, entretanto, funciona atualmente como cidade dormitório, já que seus habitantes costumam trabalhar na capital ou cidades próximas, voltando para Parnaíba somente para descansar.

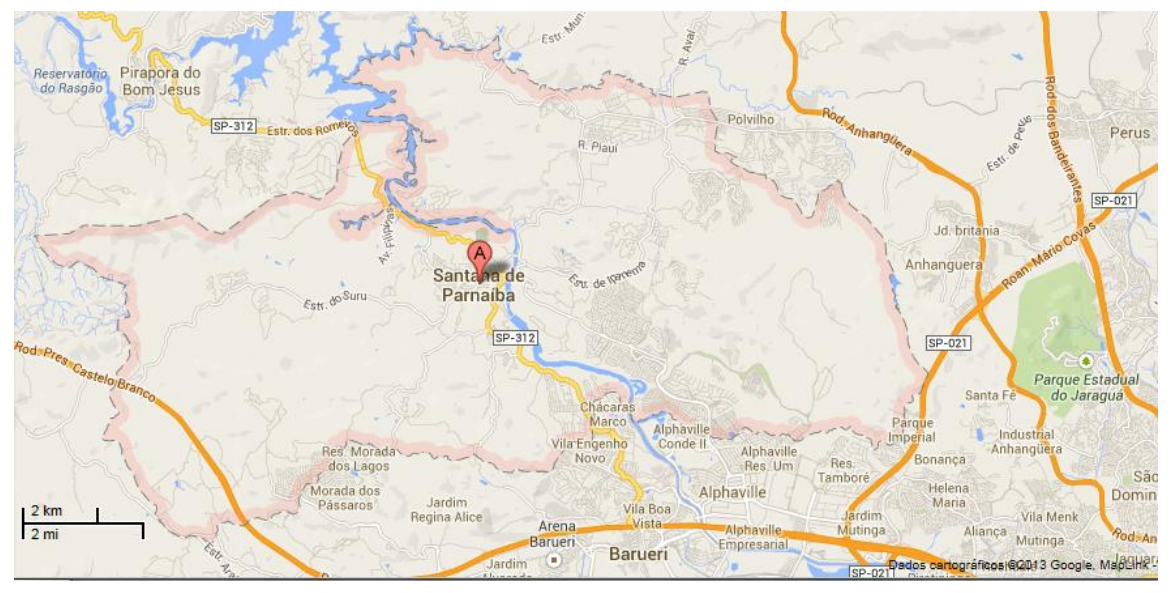

Figura 6: dados cartográficos de Santana de Parnaíba

\subsection{Pirapora do Bom Jesus}

A região de Pirapora era uma sesmaria pertencente à Santana de Parnaíba, porém, sua história tem início enquanto povoado a partir de 1725, quando, de acordo com Praem (2013), foi encontrada por José de Almeida Naves uma imagem do Bom Jesus numa pedra no rio Anhembi. 
A tradição oral da localidade conta que se tentou levar essa imagem à igreja matriz de Santana de Parnaíba, todavia, o carro de boi atolou, e, depois de diversas tentativas frustradas de locomoção, o surdomudo presente falou pela primeira vez, solicitando que a efígie permanecesse em

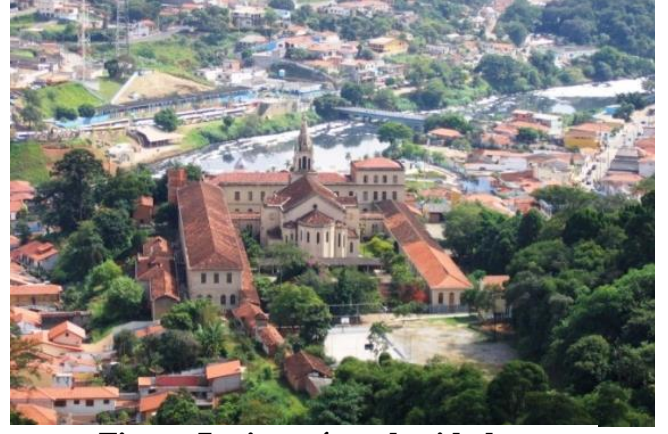

Figura 7: vista aérea da cidade

Pirapora. Por conta disso, no local em que encontraram a imagem, foi construída uma capela que favoreceu a criação de um povoado fundado em 1730 (SEADE, 2006). Segundo Praem (2013), no livro Tombo da Paróquia de Santana de Parnaíba, registrase:

Em distância de duas léguas para parte norte, junto à margem do rio Tietê e Salto de Pirapora, existe a Capela do Senhor Bom Jesus - Ecce Homo - (Eis o Homem); a gloriosa e veneranda imagem é o Orago dela e foi achada milagrosamente na beira da aguada e pesqueiro do mesmo sítio, na margem do dito rio. Só talhada em madeira e depois aperfeiçoada, e estabelecida a sua Capela perto do lugar de sua invenção.

Após a criação da capela, em 1887, a edificação foi elevada a Santuário para em 1892 ela se tornar distrito, e, somente em 1959, Pirapora recebeu sua emancipação (SEADE, 2006). Assim, percebe-se que, ao contrário das outras cidades que se apoiaram na agricultura após a descensão das caravanas bandeirantes, Pirapora do Bom Jesus teve seu desenvolvimento atrelado às razões religiosas: a cidade virou foco de romarias, com investimentos focados nas tradições do local para atender ao comércio.

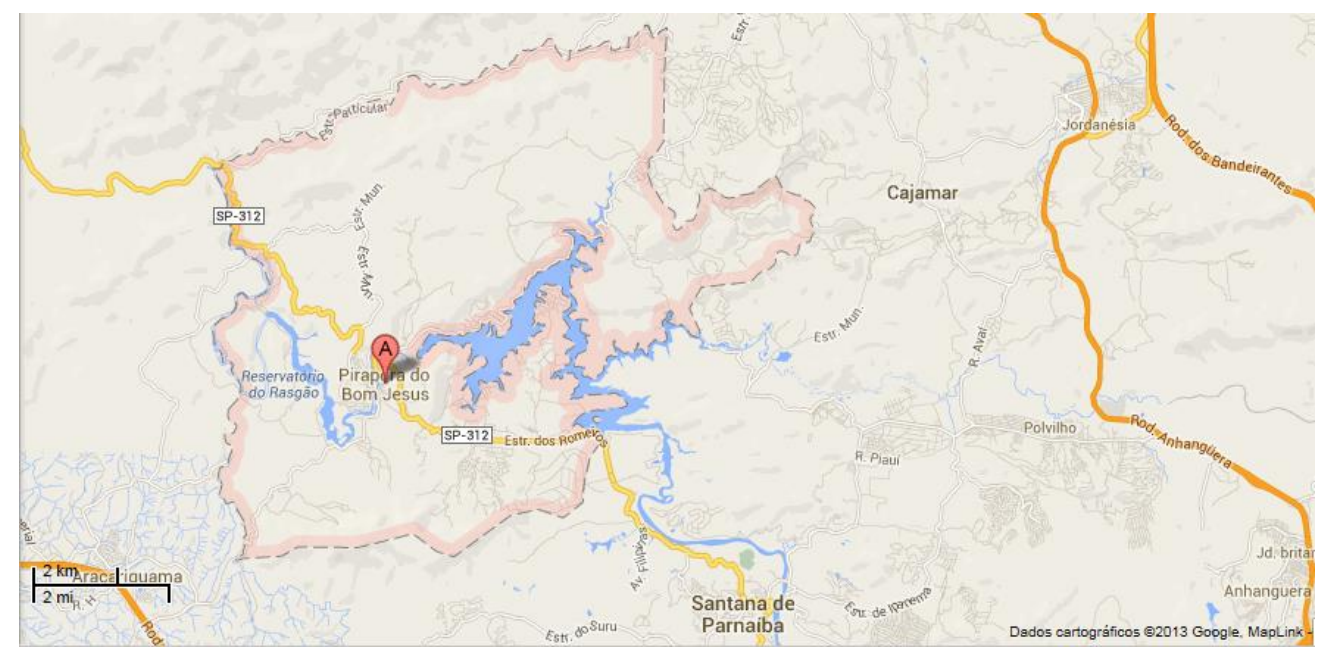

Figura 8: dados cartográficos de Pirapora do Bom Jesus 


\subsection{Itu}

De acordo com Bertolazzi (2009), o povoado de Itu remonta à data de 1610. Em 1657, o povoado é elevado à vila, desvinculando-se de Santana de Parnaíba. Segundo a autora, "durante quase 100 anos (de 1657 a 1750) a Vila de Itu [...] abrangia os atuais municípios de Porto Feliz, Piracicaba, Cabreúva,

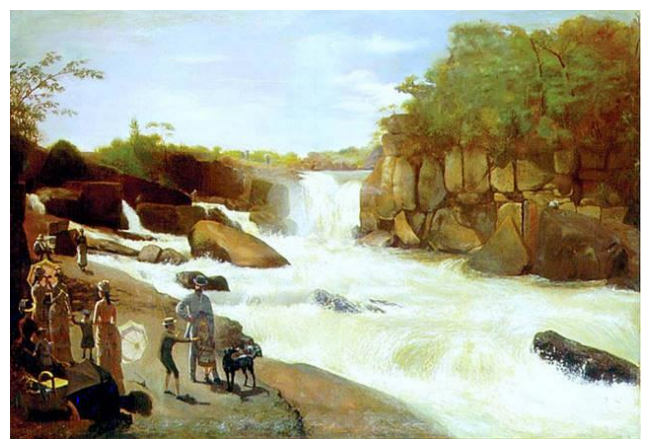

Figura 9: O salto de Itu, 1886, por Almeida Jr. Indaiatuba, Monte Mor e Salto".

Devido à fertilidade de seu solo, Itu passou de ponto de comércio para os bandeirantes (HOLANDA, 1995) à grande produtora agrícola durante os séculos XVIII e XIX. Conforme Almeida (2008, p.37-42), nesse período houve uma grande variação populacional relacionada à existência de engenhos e ofertas de trabalho. Conforme o autor, em 1836, havia 98 engenhos de açúcar, fazendo com que "um restrito número de famílias controlasse a volumosa renda da produção do açúcar, acumulando assim fortunas consideráveis". Assim, impulsionada por sua independência econômica e importância regional, “em 1842, a Vila foi elevada a cidade e, a partir de 1850, Itu foi considerada a cidade mais rica da Província de São Paulo, com importante participação na vida política e econômica" (BERTOLAZZI, 2009). Segundo a autora, em 1811, a Vila passa a Comarca que abrangia várias cidades da região e também do atual Estado do Paraná. Em 1823, Itu recebe o título de Fidelíssima pelo imperador Dom Pedro I por apoiar a Independência do Brasil.

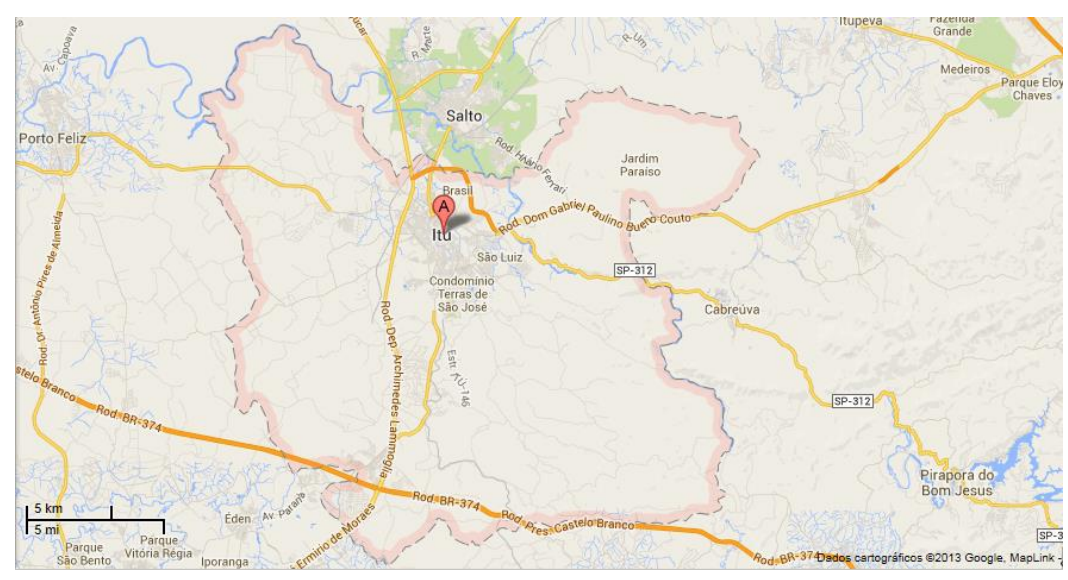

Figura 10: dados cartográficos de Itu

A decadência da produção açucareira em meados de 1860 proporcionou o descontentamento dos fazendeiros que entraram em conflito com os políticos. Desse fato, surgiu na cidade o Movimento Republicano, e dele o Partido Republicano Paulista, 
fazendo com que Itu fosse considerada o "Berço da República" por sua participação no novo processo governamental pelo qual o país passou no final do século XIX.

A cidade teve como base econômica a produção cafeeira até 1935. Entre essa data e 1950, a região estagnou, só voltando a crescer após a instalação de novas indústrias no local.

\subsection{Porto Feliz}

De acordo com Almeida (2008, p.14-18), a localidade é reportada desde 1526 como a aldeia Maniçoba dos índios Guaianazes, que utilizavam o Anhembi como meio de transporte, o qual seria também utilizado pelos bandeirantes. Tanto que o Porto de

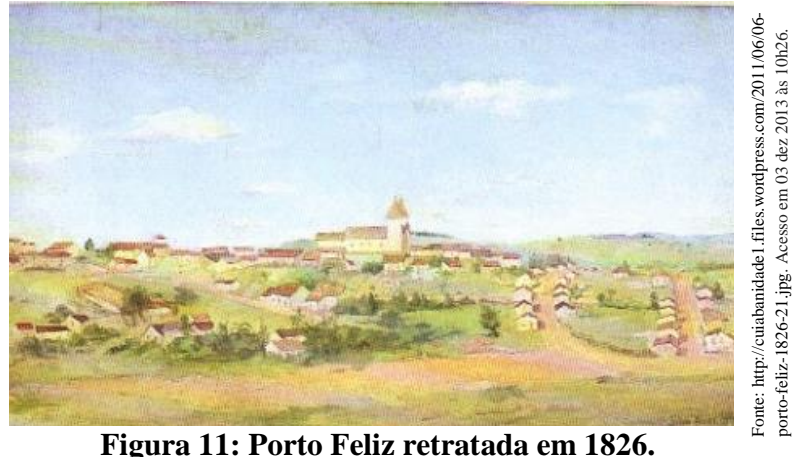

Figura 11: Porto Feliz retratada em 1826. Araritaguaba é constantemente citado em documentos históricos das outras freguesias, sendo um ponto vital para o desenvolvimento do Médio Tietê, embora fizesse parte da Vila de Itu.

Segundo Campos (2003, p.24), o povoado de Araritaguaba data do ano de 1693, porém, sua fundação é de 1700: período em que é autorizada a construção da capela Nossa Senhora da Penha, fazendo com que a localidade recebesse o mesmo nome. Assim, devido à facilidade de acesso ao Porto de Araritaguaba, o povoado prospera com as monções, desenvolvendo seu comércio, criações pecuárias e agricultura, pois de lá partiam as expedições para o sertão brasileiro. Desta forma, o porto acaba sendo apelidado de "feliz", por causa das festividades que sempre ocorriam quando na partida ou chegada das caravanas monçonenses.

Em 1750, devido ao crescimento do povoado, inaugura-se uma nova capela construída na praça central, a qual foi batizada de Nossa Senhora Mãe dos Homens, estendendo seu nome para a freguesia. Em 1797, com três mil habitantes, a freguesia é elevada a Vila por contar "com muitos moradores, comerciantes e viajantes das minas de Cuiabá" (ALMEIDA, 2008, p.17), e em 1858, à cidade de Porto Feliz, como era popularmente chamada.

Atualmente, a base econômica da cidade continua sendo a rural. 


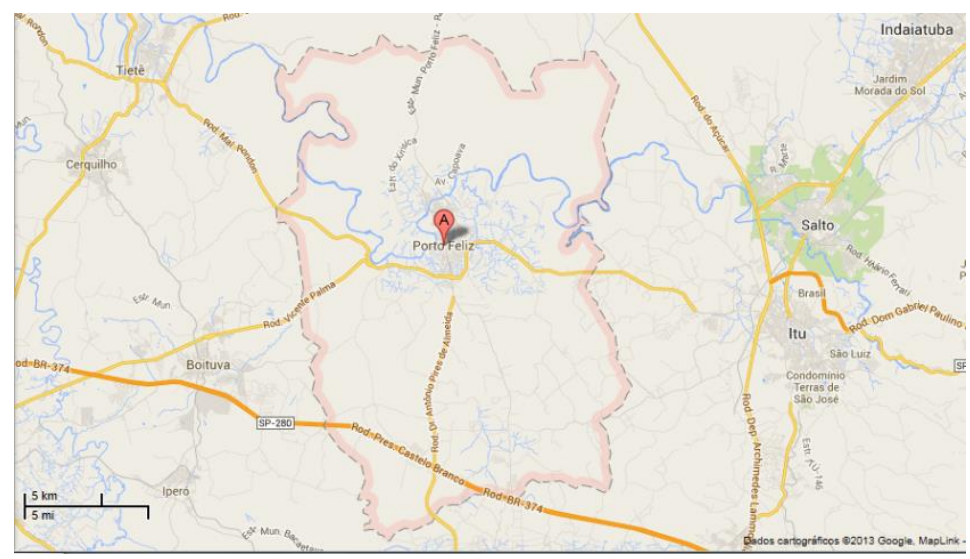

Figura 12: dados cartográficos de Porto Feliz

\subsection{Piracicaba}

Por intermédio da abertura da estrada (outrora chamada "picadão") em meados de 1721 a 1727 para facilitar as paradas das expedições em busca do ouro em Cuiabá e Goiás, Piracicaba nasceu dos povoados à beira do rio de mesmo nome e, durante seus primeiros anos de criação, estabeleceu-se em três lugares diferentes, mas sempre às margens do flúmen (PIRES, 2008).

Assim sendo, registram-se os primeiros povoamentos em 1726, embora haja apontamentos do Porto de Piracicaba desde o início do XVIII. Porém, em 1726, Rodrigo César de Menezes solicitou o fechamento dessas estradas por receio do tráfico de ouro, o que deixou a região esquecida por

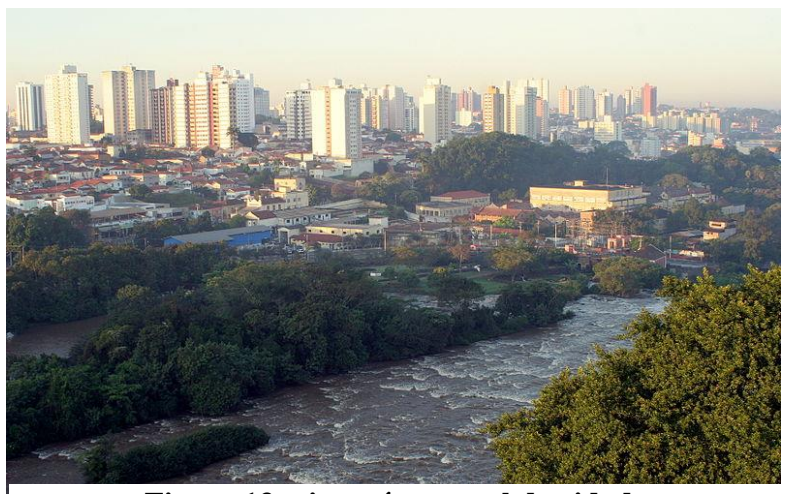

Figura 13: vista aérea atual da cidade alguns anos.

Em 1765, temendo que os castelhanos tomassem as terras ora conquistadas, Morgado de Mateus manda reabrir as picadas e incentiva o desenvolvimento dos povoamentos. Conforme Pires (2008, p.27),

Morgado de Mateus, já tendo conhecimento de roteiros de antigos sertanistas e indicações sobre antigos caminhos percorridos por estes aventureiros, mandou reabrir a estrada de São Paulo até Cuiabá, passando por Piracicaba e Campos de Araraquara, estabeleceu fortalezas e povoações e ainda projetou formar uma colônia militar de Iguatemi com o objetivo de estabelecer a posse definitiva das terras pela Coroa Portuguesa e evitar o domínio espanhol em Cuiabá e Mato Grosso.

Em 1767, ainda de acordo com a autora, Antônio Correa Barbosa "assentou uma nova povoação" em terras férteis, para efetivamente compor a região que até então era 
ocupada por posseiros, mineiros, sitiantes e criadores de gado. Nesse ínterim, o povoamento mudou-se da terra inicial para outra, por considerar o lugar "pestilento", distanciando-se dela cerca de seis léguas. Em 1774, Piracicaba é elevada a vila. Porém, em 1777 os espanhóis tomam a colônia de Iguatemi, o que faz com que a região sofra prejuízos, já que ela fora primeiramente destinada a "prover as necessidades da dita colônia militar" (PIRES, 2008, p.30), forçando os moradores a procurarem outros meios de sustento. Desta forma, a vila muda-se pela terceira vez, saindo da margem direita do rio para a margem esquerda, abaixo do salto, instituindo uma economia agrícola; construindo-se, assim, uma nova igreja matriz e iniciando o plano de arruamento da região.

Chamada de Vila Nova Constituição, Piracicaba é elevada a cidade em 1856, e em 1877 teve seu nome instituído como Piracicaba, pois era assim popularmente conhecida. Porém, somente no final do XIX, a cidade "começa a apresentar um certo desenvolvimento econômico" com a chegada da iluminação, a Estrada de Ferro Ituana, e a construção de uma fábrica de tecido, além de seu envolvimento com o movimento republicano (PIRES, 2008, p. 81).

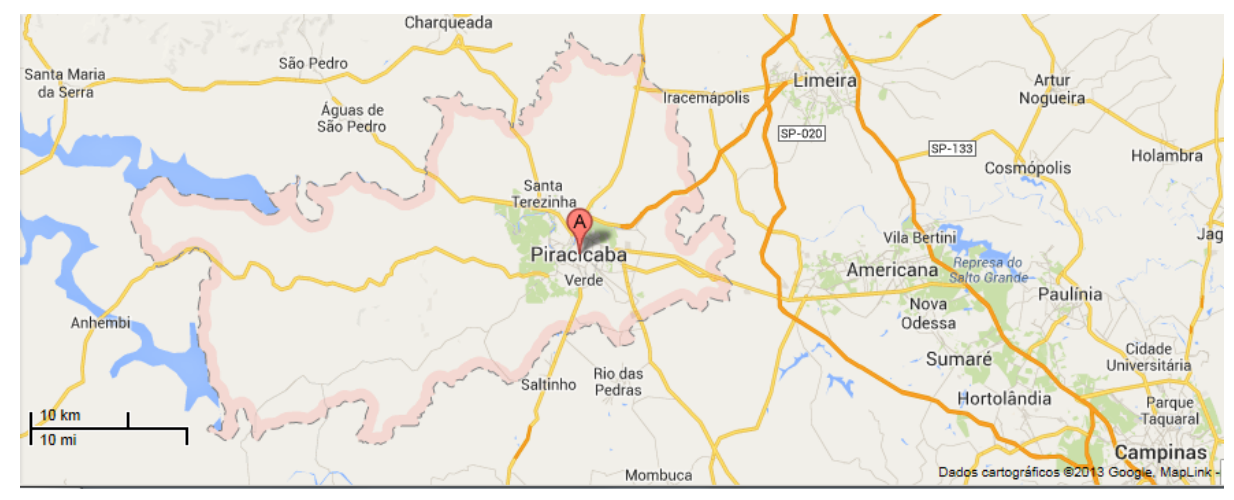

Figura 14: dados cartográficos de Piracicaba

\subsection{Capivari}

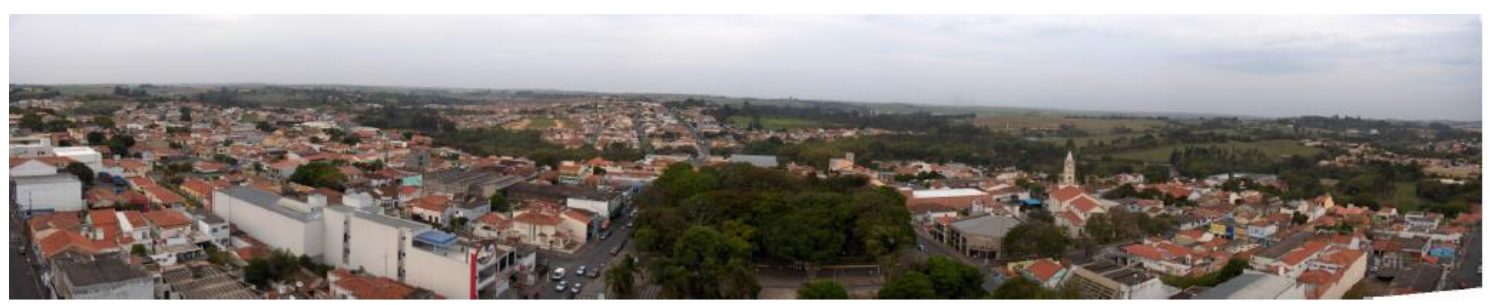

Figura 15: vista aérea de Capivari (GARCIA, 2006, p.13).

Presente em documentos históricos desde 1628 (GARCIA, 2009, p. 9), Capivari está a 108 quilômetros da capital, e efetivamente tem sua história iniciada em 1721, 
quando uma estrada foi aberta unindo Itu ao salto de Piracicaba. Todavia, a picada ficou esquecida durante alguns anos, sendo reaberta em 1765 para, conforme visto, o estabelecimento das terras devido aos interesses do Império Português em ocupar e manter a posse das terras brasileiras. Por a região ter um terreno fértil para o cultivo, as sesmarias doadas no século XVIII atraíram moradores das regiões de Itu e Porto Feliz, os quais são tidos como fundadores da cidade (CAMPOS, 1952). Assim, em franco desenvolvimento, em 1820 deu-se a criação da capela de São João Batista; em 1825 foi realizado o plano de arruamento; em 1826 a vila foi elevada a freguesia para, em 1832, o povoado ser reconhecido como Vila de São João de Capivari. Nos meados do século XIX, a linha ferroviária Sorocabana chegou à região, sendo desativada na década de 80 .

De acordo com os documentos cartoriais, a imigração europeia chegou à região na segunda metade do século XIX. Embora tenha havido uma grande influência italiana, de acordo com os moradores da região, o centro permaneceu dividido durante décadas. Grosso modo, os relatos dizem que a parte baixa (próxima ao rio Capivari) era destinada aos negros, a central (onde fica a praça e a igreja) aos brasileiros, e a alta aos estrangeiros. Atualmente, tal divisão não existe, sendo apenas história dos antigos.

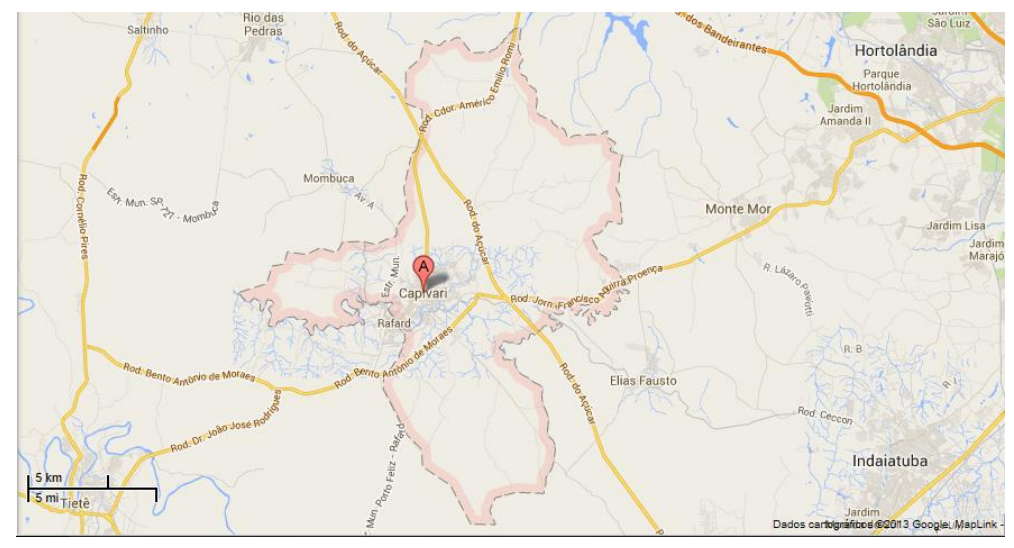

Figura 16: dados cartográficos de Capivari

\subsection{Tietê}

Localizada às margens do rio Tietê, a cidade também nasceu de povoamentos construídos à beira do rio. Segundo Firão (2009, p.29), “essa localidade era considerada um ponto estratégico para as paradas das embarcações das monções". Ligada a Porto Feliz, os moradores da região que se

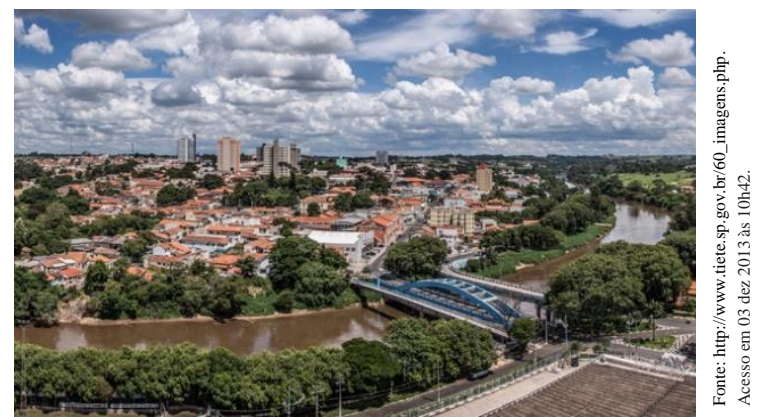

Figura 17: vista aérea de Tietê multiplicaram durante o século XVIII resolveram fazer um abaixo-assinado separando a 
então chamada Santíssima Trindade de Pirapora do Curuçá de sua freguesia, por esta estar distante cerca de quatro léguas (ALMEIDA, 1980, p. 714). Sendo assim, em 1811, o bairro foi elevado a freguesia, e, em 1842, a Vila, tendo o seu nome alterado para Tietê. Basicamente, a região é de trato agrícola.

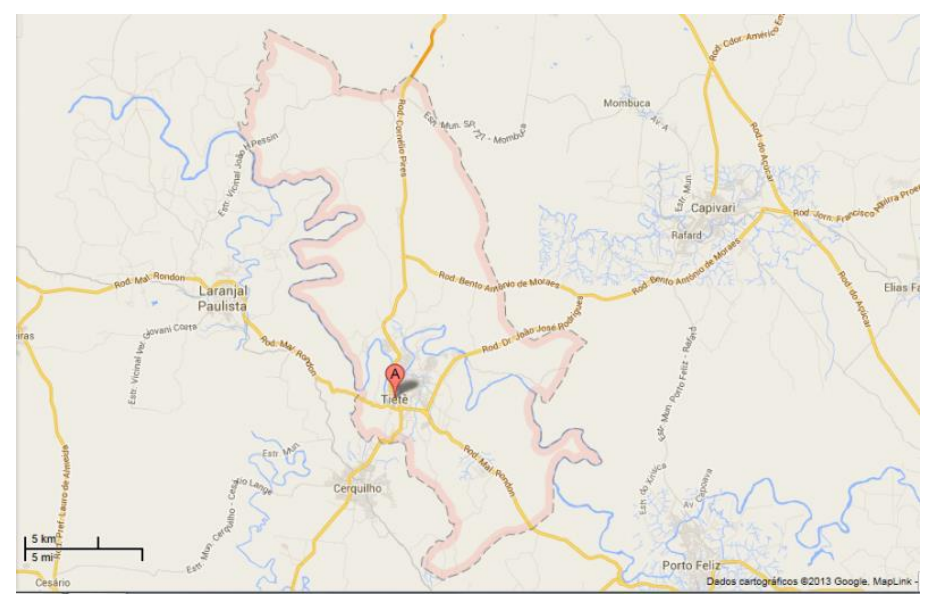

Figura 18: dados cartográficos de Tietê

\section{As cidades estudadas em Portugal}

Quando estudamos a história do Brasil, diversos nomes de colonizadores ou navegantes nos são dados. Ao buscarmos informações sobre essas pessoas, descobre-se que elas pertenciam à nobreza, e, sobretudo, foram merecedoras da confiança do rei que lhes dava como missão conhecer, colonizar as terras, e levar a Portugal o lucro dado pelas suas novas posses. Os nobres, como o próprio Pedro Álvares $\mathrm{Cabral}^{10}$, eram provenientes de diversos lugares de Portugal; porém, quanto às suas tripulações que vieram definitivamente se estabelecer aqui, não é possível determinar lugares exatos de procedência, já que pouco é falado sobre elas nos livros de história. Em Cândido (1975) e Ribeiro (1901), por exemplo, ao se falar de nossos primeiros colonos, informa-se apenas que eram degredados e desfavorecidos portugueses.

Porém, estudos socioeconômicos sobre o século XVIII em Portugal nos trazem pistas de que muitos portugueses do norte tentaram prosperar pelas terras brasileiras. Além das riquezas vistas em paredes repletas de azulejos azuis favorecidas pela exploração das terras brasileiras, Ramos (1988, p. 1088) informa que era grande o número de emigrantes lusitanos da área ora mencionada, pois, com a prosperidade que o Brasil proporcionava, a taxa de alfabetização até aumentou entre os rapazes portugueses por preocuparem-se em aprender a ler e escrever para serem caixeiros em nosso país: de acordo com as histórias que ouviam, quem era alfabetizado conseguia ter mais sucesso

${ }^{10}$ Pedro Álvares Cabral era de Belmonte, a $301 \mathrm{~km}$ de distância de Lisboa, e foi criado na corte portuguesa desde os 12 anos de idade. Aos 17, recebeu o título de moço fidalgo (NEWITT, 2005). 
em suas empreitadas. Sendo assim, tentar a vida nas terras brasileiras foi, durante muitas décadas, uma forma de esperança para os portugueses menos abastados.

A questão é que os portugueses que aqui chegavam para se estabelecerem eram, como já mencionado no início deste capítulo, analfabetos em sua maioria. De acordo com Ramos (1988, p. 1067), "por volta dos séculos XIV e XV, ainda apenas uma minoria - clérigos, burocratas, muitos nobres e alguns habitantes educados das cidades, principalmente os mais ricos — sabia ler e era capaz de escrever”. Tal quadro começaria a sofrer mudanças a partir do século XIX, quando, impulsionado pelas doutrinas iluministas que incentivaram a Revolução Francesa e, por consequência, influenciado por essa República, o movimento de alfabetização começou a se expandir. Desta forma, se em 1878, quase $80 \%$ dos portugueses eram analfabetos, cem anos depois os números reduziram para cerca de $17 \%$.

Devido à observação desses dados, as cidades de Braga, Vila Real e Bragança tornaram-se cidades relevantes, já que a história de Portugal inicia-se nessas localidades, e estas foram responsáveis por mandar muitos de seus filhos para construírem o nosso país, e, inexoravelmente, o próprio idioma falado no Brasil.

\subsection{Bragança}

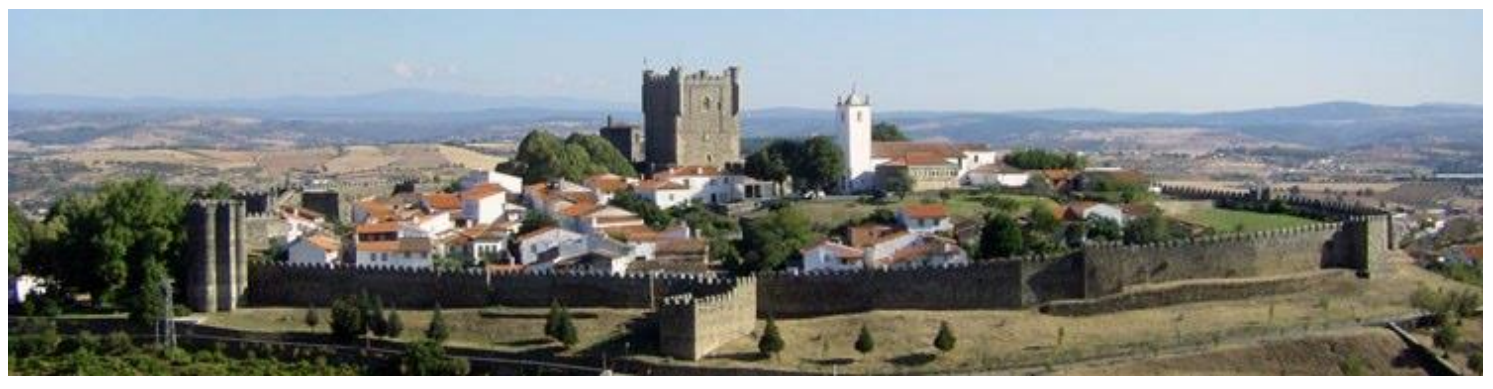

Figura 19: vista da cidade murada no castelo de Bragança

Segundo Lemos (2009), Bragança remonta sua história ao período Paleolítico, Neolítico, passando pela dominação do Império Romano até ser parte de Gallaecia e depender administrativamente de Astorga nos primeiros séculos da Idade Média. De qualquer maneira, as referências a esse topônimo (na época, chamava-se Bregancia) data o ano de 569 d.C., o que nos faz compreender que a localidade passou por todas as fases da história de sua península até se constituir como uma cidade portuguesa.

Em outras palavras, a região havia sido dominada por suevos, visigodos - sendo estes os responsáveis pela introdução de práticas agrícolas na região que são utilizadas até a atualidade - e mouros. Mas, durante o período de dominação muçulmana, os povoados do nordeste sofreram rarefação, o que foi mudado após o movimento da 
Reconquista, quando Bragança recebeu influência leonesa ${ }^{11}$ que se reflete até hoje na arquitetura, cultura, economia e na própria língua local. Militarmente bem localizada, Bragança foi uma região que mereceu cuidados por estar próxima à fronteira, isto é, o povoado funcionou como primeira linha de defesa, e, consequentemente, seus homens lutavam para defender sua liberdade (SANTANA, 2009).

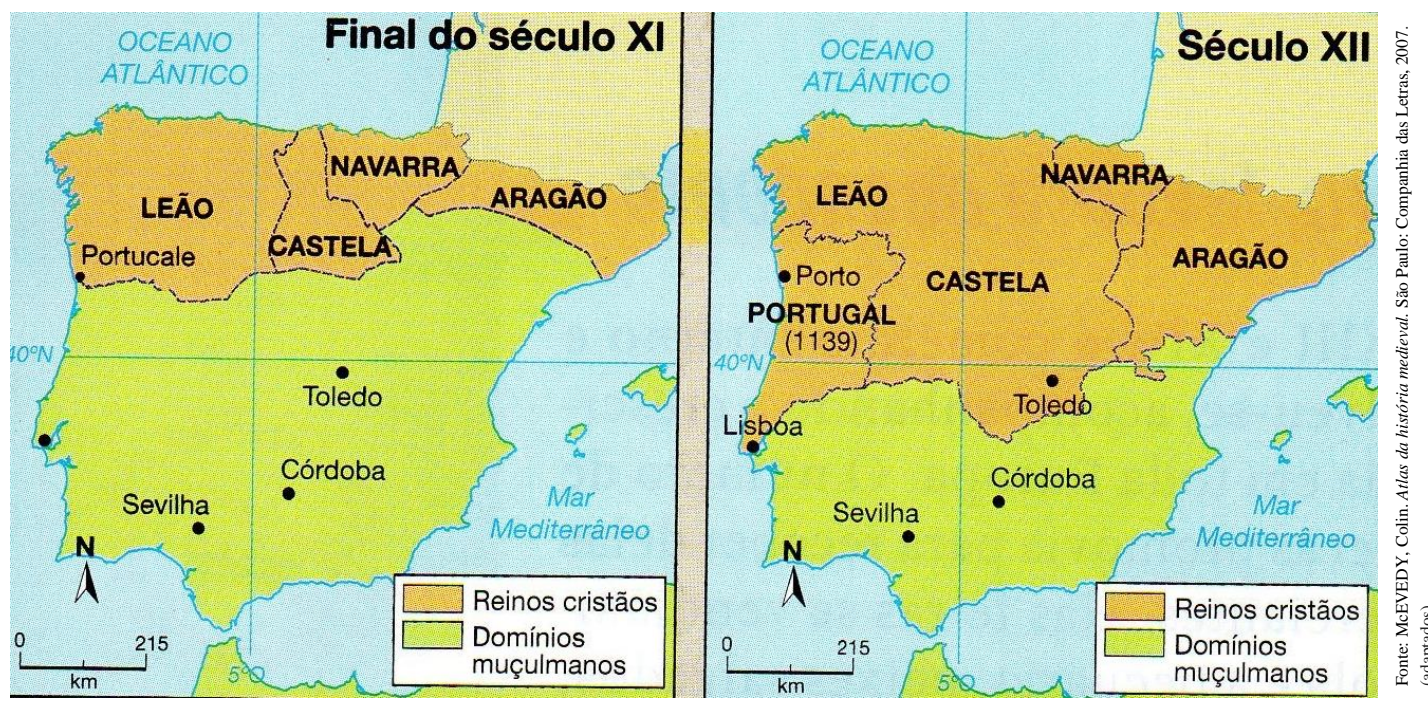

Figura 20: movimento da Reconquista nos séculos XI e XII

Por causa disso, conforme Santana $(i d$.), no século XIII a cidade possuía quatro freguesias e ocupava uma posição de prestígio perante as demais do norte. No XV, porém, os reis católicos e o processo de Inquisição expulsaram os judeus, e isso provocou a decadência da economia bragançana, pois eles levaram consigo dinheiro, contatos e experiência mercantil. Se, em 1514, Bragança era a mais populosa da região, com as crises industriais que se seguiram, ela estagnou durante os outros séculos, não passando de 6.000 habitantes até o XIX (SOUSA, 2009). Assim, a falta de perspectiva favoreceu a emigração para o centro do país e países do exterior, fazendo com que a cidade sofresse um processo de regressão, e, consequentemente, voltasse a ter como base a economia agrícola. Desta maneira, segundo Fernandes (2009), mesmo distante do mar e sem perspectiva, os habitantes de Bragança estiveram presentes no Período dos Descobrimentos, e, após, na colonização das novas terras.

Quanto à escolarização, antes do XIX, Bragança só obtinha educação voltada aos eclesiásticos, sendo que, apenas a partir de 1870, iniciaram verdadeiramente os investimentos em educação básica (FERREIRA, 2009). Porém, de acordo com Ramos (1998, p.1103), em 1843, a cidade estava acima da média em número de escolas em

11 O Reino de Leão fez parte dos antigos reinos ibéricos do período da reconquista cristã, sendo independente de 910 a 1037 (casa Leonesa), de 1065 a 1072 (casa de Navarra) e de 1157 a 1230 (casa da Borgonha). (HERCULANO, 1863) 
comparação a outros distritos da região, estimando-se que o município possuía 3,2 escolas por 10.000 habitantes, tendo suas professoras provindas de famílias camponesas proprietárias e abastadas - enquanto os filhos homens eram destinados a serem “doutores” (DESCAMPS, 1935). Embora, para o período, o número de escolas fosse uma conquista, tais informações demonstram que essa porcentagem não atinge verdadeiramente as necessidades básicas da população.

\subsection{Braga}

Braga foi fundada durante o tempo de domínio do Império Romano sob o nome de Bracara Augusta, em homenagem a César Augusto Bracara Augusta, e veio a ser a capital da Gallaecia. Após a queda do Império, a cidade continuou sendo a capital política e intelectual do reino dos Suevos, até ser destruída pelos mouros em 716 devido a sua importância política, e, somente a partir de 868 , foi reconstruída por Afonso III, rei das Astúrias (MARTINS, DELGADO, 1989).

De acordo com as autoras, no século XI, a cidade é reorganizada, e são construídas a muralha do castelo e a Igreja da Sé. Nesse período, a

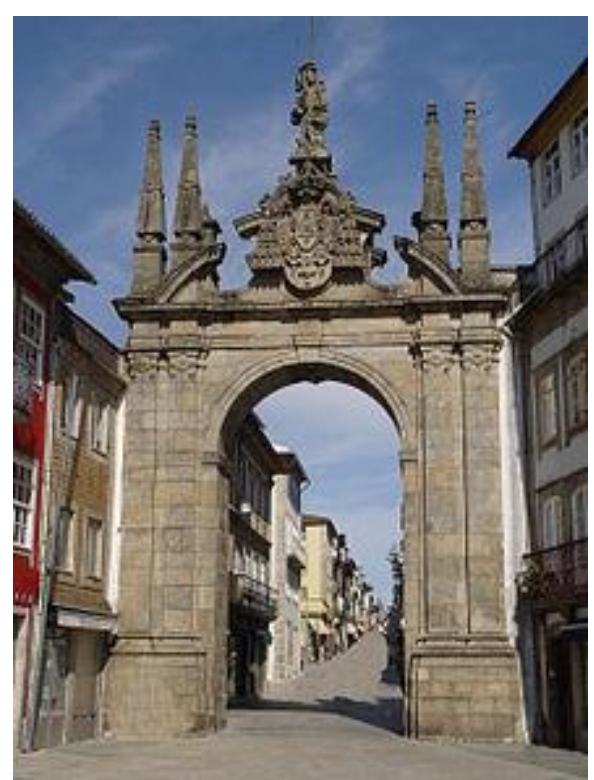

Figura 21: Arco da Porta Nova, foto atual de uma das entradas da muralha. localidade é dada por Afonso VI de Castela à sua filha D. Teresa, por ocasião de seu casamento com Dom Henrique de Borgonha, Conde de Portugal. Braga ficou sob seus domínios de 1096 a 1112, quando foi doada aos arcebispos, tornando-se conhecida como arcebispado de Braga (BRANCO, 1993). Com isso, a cidade voltou a ter prestígio e investimento, algo demonstrado por sua arquitetura que foi mudando ao longo dos séculos: segundo Rocha (2010-2012), entre os séculos XVI e XVIII, Braga recebeu as influências barrocas e neoclássicas sob orientação da igreja. No início do XIX, porém, a região foi palco de várias batalhas por causa da invasão francesa e das lutas liberais (ARAÚJO, 1993), o que a fez, novamente, sucumbir. Somente na segunda metade do século XX, ela se estabelece economicamente, tendo hoje, conforme Marques (2014), o comércio como principal atividade econômica, de modo a servir como exemplo a outros locais. 
Porém, antes de adentrar nessa realidade atual, dos séculos XVI ao XIX, a base da economia era agrícola, e Ramos (1998, p. 1080) informa que o número de alfabetizados tende a ser menor nas áreas rurais assalariadas e isoladas, gerando, assim, uma grande porcentagem de analfabetos: em 1878, contava-se

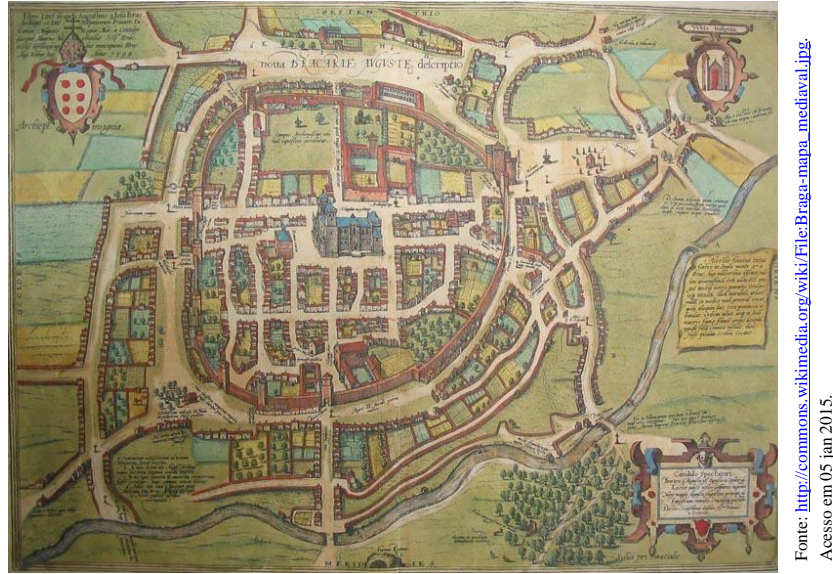

Figura 22: Mapa de Braga de 1594 $38,9 \%$ de homens alfabetizados, e apenas $9 \%$ das mulheres de Braga e suas freguesias. Ademais, a cidade estava dentre as localidades do Noroeste atlântico tradicionais de emigração (RAMOS, 1988, p. 1089). Segundo Leite (1999, p. 190), a taxa de emigração de Braga em 1864 era alta em relação às outras regiões, sendo 5,8 emigrantes por mil habitantes, ficando atrás apenas de Aveiro $(6,09)$.

Ou seja, mesmo tendo sido um importante arcebispado e houvesse uma tendência maior de acesso ao ensino da escrita e leitura pelos meninos e meninas (RAMOS, 1998, p.1094) - as cartilhas eram fornecidas pelo clero para a catequização -, a realidade de Braga não ficava muito distante das outras regiões, de forma que seus concidadãos também fizeram parte da Era dos Descobrimentos tendo em vista a própria melhoria financeira.

\subsection{Vila Real}

Vila Real tem sua história também ligada ao Império Romano, incluindo o seu primeiro nome, Terra de Panoias. Porém, durante as invasões bárbaras e muçulmanas, a área sofreu despovoamento, situação modificada em 1096, quando, por meio de um foral a Constantim de Panoias, D. Henrique estimula a ocupação do local (SOUSA,

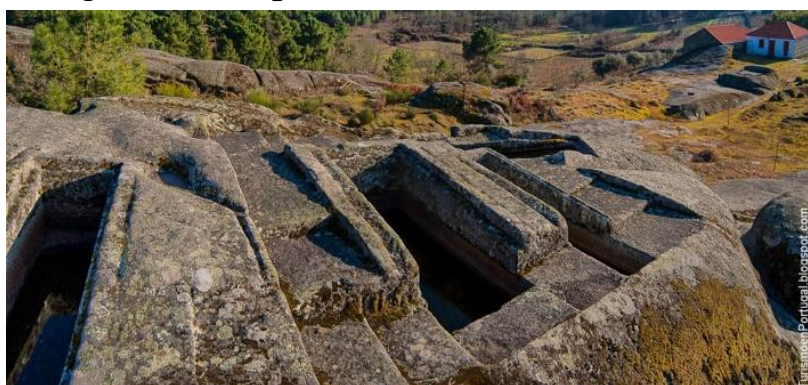

Figura 23: uma das fragas do Santuário de Panoia. Nela estão talhados três receptáculos utilizados para batizado após sacrifício de animais 2013, p.271).

Vila Real está situada em um planalto entre dois vales, logo, sua posição defensável influenciou na escolha da localidade para seu povoamento e organização administrativa (SOUSA, 2013, p. 277). Sua instauração foi promovida por meio de sucessivos foros, até a efetiva fundação em 1289. 
Segundo Sousa (2013), Vila Real constituiu-se como uma área rural, mas, sobretudo, transformou-se num domínio senhorial dos séculos XIV a XVIII, que fazia com que houvesse um pleno comando da nobreza sobre a sociedade vila-realense. Isso significa que não havia mobilidade de classe social, e assim, a matriz aristocrática mantinha-se e ditava tanto as normas administrativas quanto os hábitos de sua população. De acordo com o autor, os camponeses costumavam imitar os costumes da nobreza por viver entre eles - pois suas casas estavam nas freguesias onde a população menos abastada também vivia. Deste modo, o povo adotava "os seus costumes e hábitos cortesãos, os seus trajes asseados (à moda da Corte), os seus 'divertimentos festivais', a sua linguagem grave e polida".

Assim, sendo uma região influente, mesmo estando longe do litoral, há grandes nomes da navegação naturais de Vila Real, como Fernão de Magalhães, o idealizador da primeira viagem de circum-navegação do globo terrestre (HERCULANO, 1863). Quanto à emigração, Sousa (2013) confirma sua existência ao constatar que "indivíduos oriundos do povo que, uma vez abandonada a terra natal, não mais gostarão de ser 'conhecidos por humildes'”. Nos registros de 1864, a taxa de emigração marcada na região era maior que a média do continente: enquanto esta era de 1,29 por mil habitantes, em Vila Real era de 2,63.

Outro número que impressiona para o período é o da alfabetização. Vila Real destacava-se com outras regiões do Nordeste por terem 3,2 escolas por 10.000 habitantes (RAMOS, 1998, p.1104) registrados em 1781. Desta maneira, a taxa de alfabetização era alta para a época, apresentando o valor de $38,4 \%$ entre os homens, em 1878.

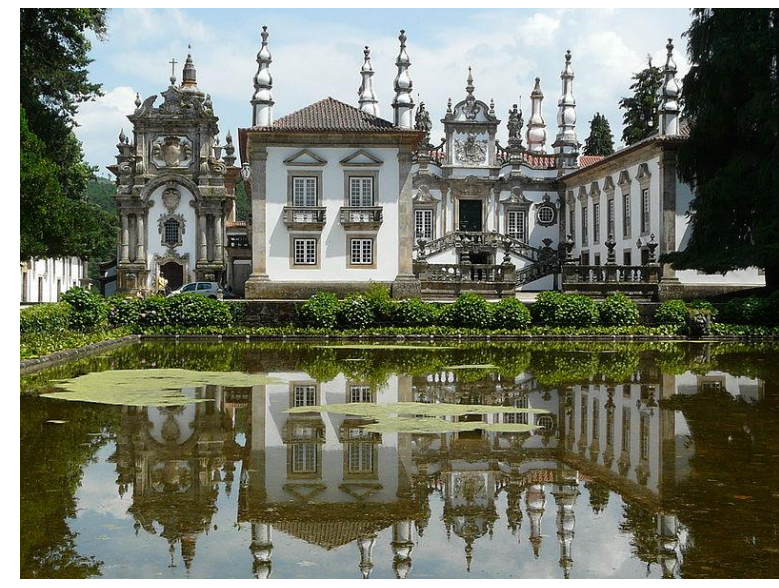

Figura 24: Palácio de Morgado de Mateus

\section{A comunidade caipira}

Como visto, a formação dos povoamentos possuía características comuns. Pensando primeiramente em Portugal, percebe-se que os portugueses que vieram para o Brasil eram economicamente desfavorecidos e não tinham escolaridade. Haja vista registros oficiais que se iniciam apenas após a segunda metade do século XIX, a educação apenas passou a ser uma preocupação política após o estabelecimento das fronteiras e das políticas europeias. 
Em relação às cidades do Médio Tietê, Darcy Ribeiro (2002) e Antonio Candido (1975) chamam-nas de naçõezinhas, por viverem de forma independente e possuindo características próprias. Segundo eles (RIBEIRO, p.195; CANDIDO, p.71), nessas cidades, suas principais edificações eram as igrejas, sendo que "a atividade religiosa regia o calendário da vida social, comandando toda a interação entre os diversos estratos sociais" (RIBEIRO, p.378). Saint-Hilaire (1837, p.171) escreveu que "o cumprimento das obrigações religiosas os impede, talvez mais do que qualquer outra coisa, de cair em um estado próximo da vida selvagem”. De acordo com Ribeiro, os povos dessas vilas foram "marginalizados do processo econômico da colônia" (2002, 368), e sua população "era constituída de 'brancos' que seriam quase todos mamelucos" (ib.). Para ele (2002, p.366),

[...] esse modo de vida, rude e pobre, era resultado das regressões sociais do processo deculturativo. Do tronco português, o paulista perdera a vida comunitária da vila, a disciplina patriarcal das sociedades agrárias tradicionais, o arado e a dieta baseada no trigo, no azeite e no vinho. Do tronco indígena, perdera a autonomia da aldeia igualitária, toda voltada para o provimento da própria subsistência, a igualdade do trato social de sociedades não estratificadas em classes, a solidariedade da família extensa, o virtuosismo de artesãos, cujo objetivo era viver ao ritmo em que seus antepassados sempre viveram.

Desta maneira, Darcy afirma (id., p.371) que em São Paulo, devido à sua mistura étnica, surge "uma configuração histórico-cultural de povo novo, plasmada pelo cruzamento de gente de matrizes raciais díspares e pela integração de seus patrimônios culturais".

Candido compartilha do mesmo ponto vista, e acrescenta que o caráter caipira, seus costumes e moradia tinham características efêmeras (1975, p. 37):

A combinação dos traços culturais indígenas e portugueses obedeceu ao ritmo nômade do bandeirante e do povoado, conservando as características de uma economia largamente permeada pelas práticas de presa e coleta, cuja estrutura instável dependia da mobilidade dos indivíduos e dos grupos. Por isso, na habitação, na dieta, no caráter do caipira gravou-se para sempre o provisório da aventura.

Portanto, nota-se que a constituição dessa cultura foi realizada de modo particular: primeiramente, a população não era pertencente a uma única etnia, mas proveniente da miscigenação entre portugueses e índios, e, tendo em vista a história de Santana de Parnaíba, notamos que pessoas tidas com importância política - como é o caso de Suzana Dias - eram mestiças, comprovando que não havia preconceito quanto a isso. Em outras palavras, na sociedade caipira, não havia preferência ou escolha de 
líderes por meio de sua cor, logo, posições de prestígio eram abertas normalmente aos caboclos.

Ademais, todos os registros históricos demonstram que as comunidades ora estudadas passaram por dois momentos de colonização e posteriores isolamentos: durante as entradas e, depois, com as bandeiras, as paragens originaram diversos povoamentos que se tornaram ermos. Anos após, como o interesse da coroa era de estabelecer as terras brasileiras, outros grupos de emigrantes foram enviados para essas regiões mais afastadas para aumentar-lhes o número de habitantes. Porém, sem contato com outros meios, os grupos mantiveram costumes e hábitos remotos.

Quanto à educação, de acordo com Garcia e Da Silva (2012), embora a Constituição Política do Império do Brasil de 1824 previsse por lei que toda a população, indistintamente, devesse ter acesso à educação básica, o processo de alfabetização das vilas brasileiras deu-se tardiamente: nos documentos das cidades, demonstra-se que por volta de 1830 havia a preocupação com a construção de escolas e escolhas de mestres, porém, o número de alunos efetivamente presentes era sempre abaixo da expectativa, pois muitas famílias preferiam que seus filhos trabalhassem para o sustento familiar a ter educação. Desta forma, apenas saber ler e escrever já era o suficiente para muitos. Segundo os entrevistados para esta tese, tal realidade não mudou até meados do século XX, o que inclui os relatos de Portugal, que serão vistos no capítulo 2 .

Destarte, concluímos que a cultura caipira foi formada por pessoas de baixo ou nenhum grau de escolaridade, e, segundo Candido (1975) e Ribeiro (2002), essas pessoas mantinham-se isoladas em suas comunidades, envolvidas com suas próprias atividades. Aplicando-se o método neolinguístico ou espacial de Bartoli (1945) em que se diz que localidades mais isoladas tendem a conservar alguns traços de variações linguísticas, vemos que o ambiente descrito propicia a sua manutenção. Isto é, os atributos atuais do DC têm como base a sua formação cultural. 


\section{CAPÍtulO 2}

A metodologia e a pesquisa de campo 


\section{A metodologia e a pesquisa de campo}

Conforme apresentado no capítulo 1, compreender a metodologia, assim como a situação histórico-econômico-social da localidade estudada, é fundamental para entendermos o seu desenvolvimento linguístico. Por isso, perceber-se-á neste capítulo a preocupação de explicar ao leitor os pormenores da pesquisa, relatos e vivências dos moradores da região, pois, a partir do momento em que o pesquisador tem o domínio dessas informações e demonstra ser conhecedor da região, percebe-se que:

1. O pesquisador passa confiança para o informante, que se torna mais receptivo;

2. Há mais facilidade para a articulação de questionamentos e condução da entrevista para aquilo que se deseja coletar;

3. As respostas dos entrevistados tendem a manter as mesmas características orais, o que facilita para a edição de trechos e análise de frases selecionadas.

Ao todo, foram realizadas cerca de 50 entrevistas, mas, das amostras coletadas nas cidades do Médio Tietê e de Portugal, foram escolhidos 40 informantes; e 20 gravações de apresentadores de telejornais para servirem como controle. As entrevistas foram coletadas e registradas em ambientes externos em um gravador digital portátil de marca Zoom H4.

Em relação às gravações em ambientes externos, o que determinou a seleção foi a qualidade do áudio, a participação do entrevistado durante o desenvolvimento da conversação e as informações dadas durante as entrevistas. Ademais, para computação dos dados, eram necessárias pessoas maiores de sessenta anos, com baixo grau de escolaridade e que não tivessem morado por longa data em outros lugares.

A preferência pelos maiores de 60 anos se dá pelo mesmo motivo da escolha das cidades: busca pela manutenção de variações. E, em relação às frases, separaram-se somente as orações assertivas, porque, durante o processo narrativo a que os informantes foram submetidos, elas aparecem em grande número e mais informacionais.

Escolhidas as frases, os arquivos sonoros foram editados e segmentados com o programa Audacity 1.3.12 Beta (Unicode). A análise e a conversão da curva de frequência fundamental e da curva de intensidade para arquivos de texto foi realizada pelo software Speech Filing System (HUCKVALE, 2008), e os valores gerados por ele foram analisados pelo aplicativo ExProsodia (FERREIRA-NETTO, 2010). 


\section{Buscando os informantes no Médio Tietê e em Portugal}

Para dar início à pesquisa, foram realizadas viagens às cidades do Médio Tietê e Portugal, e, em praça pública, buscaram-se informantes que, fisionomicamente, aparentavam ter a idade que atendiam aos requisitos da pesquisa. Ou seja, não houve a seleção de um líder (LABOV, 2001) ou a intenção de se criar uma rede, pois a proposta desta análise foi justamente coletar informantes aleatoriamente, de preferência que não tivessem relação entre si, de modo a comprovar um traço comum linguístico entre a população que não necessariamente tivesse a ver com graus de proximidade. Isso se deve porque, segundo Labov, membros de uma mesma comunidade costumam ter elementos semelhantes na fala, tornando-se mais evidente de acordo com suas cognações: familiares, colegas de trabalho, entre outros.

Assim, apenas dois informantes de Itu e três de Vila Real são conhecidos um dos outros, pois estavam juntos quando foram abordados e todos se encaixaram nos objetivos da pesquisa. Os demais, no entanto, não se conhecem ou não têm relação muito próxima.

Ressalta-se que o objetivo da pesquisa era a narrativa por meio de fala espontânea com pouquíssima intervenção do pesquisador (BARBOSA, 2012, p.15). De acordo com o autor, a fala espontânea pode ser considerada desde a conversação livre à leitura quando "ocorrerem em situação natural de comunicação" (BARBOSA, 2012, p.14), mas o que definirá a verossimilhança do corpus é a forma como a entrevista for conduzida. Como a proposta foi buscar o dialeto em sua forma natural, estabeleceu-se, primeiramente, que os entrevistados não seriam levados a um local de coleta de gravação especial, de modo que eles não se sentissem pressionados. Ou seja, conversouse com os informantes em seu habitat natural, nos locais que costumam estar, e, embora as perguntas fossem introduzidas pelo entrevistador, dava-se liberdade para que eles discorressem sobre o tema sem mais nenhum tipo de intromissão. E, em busca da naturalidade, decidiu-se fazer entrevistas de 15 a 20 minutos, pois o informante tende a se tornar mais desenvolto no decorrer da narrativa. Desta maneira, de cada gravação, selecionaram-se trechos de 15 a 20 segundos que tivessem sido ditos em momentos mais descontraídos.

A coleta aconteceu com a presença de dois pesquisadores, um homem e uma mulher, de forma que os entrevistados escolhessem com quem gostaria de falar, pois, observamos, que nem todos se sentem à vontade com uma pessoa desconhecida do sexo oposto. Assim, em conjunto, notou-se que ambos os sexos traziam mais conforto para que a pessoa pudesse conversar, e ainda existia a possibilidade de um pesquisador 
ausentar-se, deixando que o outro conduzisse os questionamentos. Isso foi feito, pois, às vezes, o informante acabava dando mais atenção apenas para um entrevistador, no entanto, tal atitude não trazia dificuldades à coleta.

Na cidade de Santana de Parnaíba, a pesquisa ocorreu nas próprias casas dos moradores, tendo em vista que as pessoas com mais idade, por serem mais reservadas, não estavam passeando pela rua quando estivemos no local. Devido a isso, dois informantes foram vistos na janela de suas residências, e, assim, foram convidados a participarem da coleta. Os outros dois foram indicações de outras pessoas da cidade, das quais se perguntou a respeito, já que esses moradores não estavam nas ruas. Dessa maneira, uma senhora, por ser herdeira de uma das padarias mais antigas do Brasil, e outro indicado por um vizinho enquanto passávamos em uma rua do centro histórico, foram entrevistados e receberam gentilmente os pesquisadores em suas casas.

Os centros históricos de Pirapora do Bom Jesus e Itu, todavia, são basicamente centrados no comércio por receber muitos turistas todos os finais de semana. Itu, por ter sido apelidada de "Cidade dos Exageros" pelo humorista Francisco Flaviano de Almeida, o Simplício do programa humorístico A Praça da

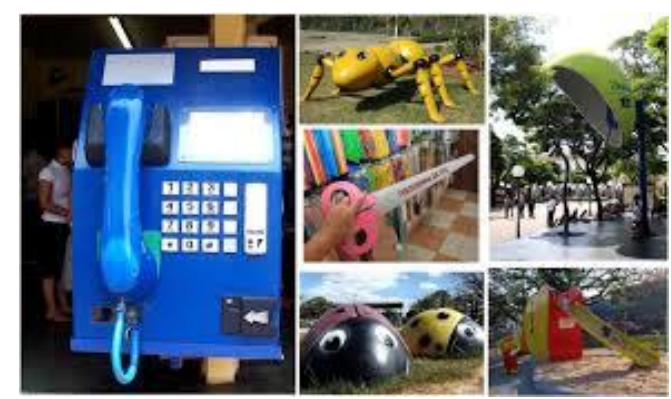

Figura 25: esculturas, monumentos e objetos em tamanhos exagerados de Itu Alegria na década de 1960, reúne muitos visitantes atraídos por objetos gigantes colocados na praça central, como o semáforo e um orelhão, além de suvenires vendidos pelas lojinhas da cidade (GREGORIO, 2011). Já em Pirapora do Bom Jesus, há a visitação frequente de romeiros que vêm pagar suas promessas na Igreja Matriz, local onde está a imagem do Bom Jesus encontrada no rio. Ao contrário de Santana de Parnaíba, há muita movimentação nas ruas dos centros históricos, e é possível encontrar as pessoas mais idosas circulando, sendo também os comerciantes do local. Contudo, os entrevistados selecionados foram abordados em seus locais de trabalho, e apenas um em Pirapora estava na rua a auxiliar uma amiga e conversando sobre assuntos afins.

Nas demais localidades, alternou-se entre encontrar os entrevistados em praça pública, passeando, ou por indicações de outras pessoas a quem eram interpeladas pelos pesquisadores pelas ruas da cidade.

As entrevistas aconteceram de forma descontraída, porque, ao contar sobre as suas infâncias, namoros, casamentos, flertes, e fazerem uma viagem ao passado por meio de suas memórias, grande parte dos informantes ficava desenvolto. E seguiu-se uma das propostas da pesquisa: não houve a utilização de questionários prontos a fim de 
que o entrevistado não monitorasse sua fala. E, quanto mais envolvido ele estivesse no assunto, mais natural se tornava seu discurso.

Um tópico comum entre todos foi a forma de paquera nos tempos idos. Exceto em Pirapora do Bom Jesus, todas as cidades paulistas tinham uma praça central em frente ou muito próximo à Igreja Matriz, onde os jovens costumavam ficar, após as missas, para passar tempo e flertar. Em praticamente todas as entrevistas foi contado que os jovens solteiros costumavam ficar rodeando a praça, porém, os

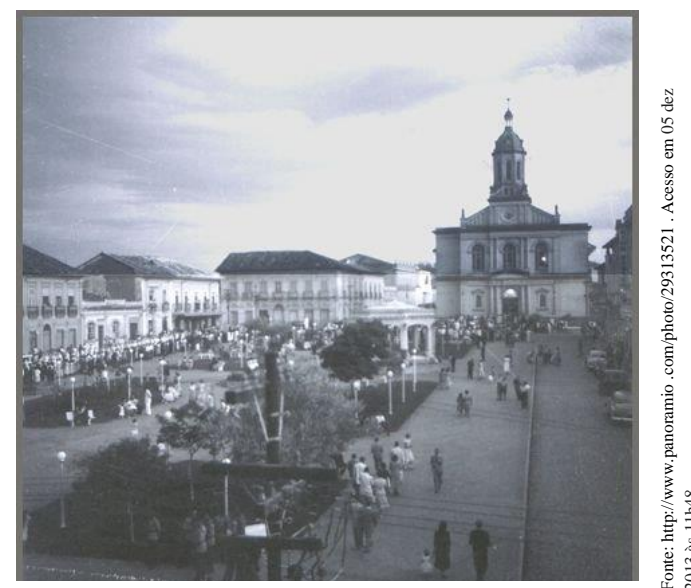

Figura 26: Igreja da Matriz, na Praça Padre Miguel, Centro de Itu - 1950 homens giravam em um sentido e as mulheres em sentido contrário. Quando havia algum interesse, o casal parava e conversava, e dali nascia um relacionamento de namoro ou amizade.

Pirapora do Bom Jesus foi excetuada devido à sua característica urbana: a cidade não tem uma praça central como as outras, porquanto a Igreja Matriz está situada em frente ao rio Tietê, havendo um largo em sua fronte. Atualmente, há uma construção em ambas as margens favorecendo a arquitetura do local, porém, de acordo com o depoimento dos informantes, tal construção é recente. Eles lembraram que o rio praticamente desembocava frente à igreja, local de pesca farta e divertimento, e costumavam nadar nas águas do Tietê quando eram crianças e jovens. Todavia, após a implantação da Pequena Central Hidroelétrica Rasgão, as características do rio começaram a mudar devido ao fechamento e abertura das comportas. Após, aterraram uma das margens e construíram um monumento valorizando a localidade. De qualquer maneira, os jovens costumavam se encontrar na rua em frente à Matriz ou no próprio comércio impulsionado pelas romarias que ocorrem desde que encontraram a imagem do Bom Jesus.

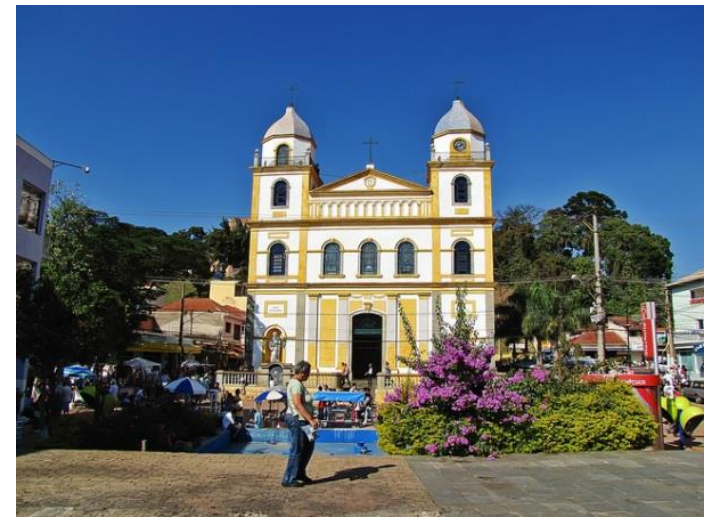

Figura 27: Frente da Igreja Matriz de Pirapora do Bom Jesus. Esse local, de onde se está tirando a fotografia e se vê uma pequena vegetação florida, faz parte da reforma realizada em $\mathbf{1 9 9 5}$, chamada hoje de "Praça do Encontro" por causa das romarias.

Logo, percebe-se que, ainda no século XX, a presença da religião - como visto em Ribeiro (2002) quando mencionava o desenvolvimento dos povoados nos séculos anteriores - era um fator determinante para a socialização dos moradores, pois, quando 
não havia missa ou festas promovidas pela igreja, os entrevistados contaram que não havia outras formas de diversão ou contato com outras pessoas.

Em Portugal, por sua vez, estabeleceram-se os mesmos critérios de pesquisa tidos no Brasil: em Braga, buscaram-se pessoas idosas pelas ruas, mas foi nas portas das igrejas que se obteve mais sucesso, pois, por serem cidades que ainda sustentam hábitos

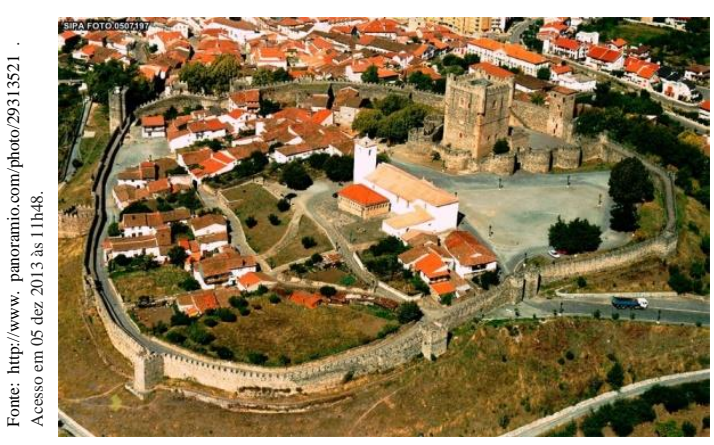

Figura 28: Vista aérea do Castelo de Bragança e a vila murada católicos, muitos idosos são frequentadores de missa. Por isso, nos arredores das igrejas, encontramos informantes que se encaixavam na pesquisa. Em Bragança, todavia, os idosos eram moradores da vila murada do Castelo: caminhando pelas ruas, eles eram encontrados tomando sol no lado de fora de suas residências.

Em relação à Vila Real, a pesquisa teve de se estender para a freguesia de Parada do Pinhão, local com 309 habitantes (de acordo com o Censo de 2011), pois o centro histórico, ao contrário das outras localidades, era pequeno e nosso público alvo não seria encontrado facilmente. Deste modo, fomos até a freguesia, cujos moradores eram idosos em sua maioria, trabalhadores rurais, e atendiam aos critérios. Lá, foram encontradas três pessoas dispostas a conversar, duas mulheres e um homem. O último informante era artesão e foi achado no centro de Vila Real vendendo suas peças de barro preto.

O tema principal dos diálogos envolvia o período da Guerra de Independência de Angola (1961-1974), o sofrimento causado por ela, a escassez de alimentos que tinham no período e o trabalho infantil (quase todos informantes começaram a trabalhar quando crianças). Ao contrário do Brasil, as memórias das infâncias e adolescências dos informantes portugueses eram mais sofridas, já que passaram necessidade devido à política econômica da época, e ainda a maioria dos homens serviram o exército quando jovens. Além disso, a maioria estudou somente as primeiras classes - em Portugal, o termo é utilizado para designar a série escolar, equivalendo-se ao tempo de estudo brasileiro.

\subsection{Descrição dos informantes}

Em cada cidade do Médio Tietê e Portugal, foram selecionados 4 (quatro) informantes, sendo dois homens e duas mulheres, como já dito. De cada informante, coletaram-se 5 frases, totalizando 20 dados comparativos para cada cidade. 
A nomenclatura que os nomeia nos subitens é uma codificação utilizada para os estudos de entoação, já que, de suas falas, foram tirados os recortes para análise. Portanto, as três primeiras letras referem-se ao nome da cidade abreviado; o número determina o informante; $\mathrm{M} / \mathrm{H}$ ao sexo; o asterisco será substituído pelo número da frase analisada no capítulo 3. Seguem resumidamente o conteúdo das conversas e as descrições dos informantes.

\subsubsection{Santana de Parnaíba}

O diálogo comum entre os homens foi sobre o rio e de como ele proporcionava fartura na região, e como a empresa de energia e a poluição vinda de São Paulo prejudicaram a ecologia na região. As mulheres, porém, falaram mais de si, de suas vidas e de seus hábitos na juventude.

- SAN*H1: o informante 1 é um senhor de 79 anos, viúvo, e estudou até o $4^{\circ}$ ano do ensino regular. Nascido e criado em Santana de Parnaíba, o entrevistado foi adotado por uma família após a morte da mãe e cresceu em uma chácara da cidade, onde viviam da agricultura de subsistência.

- SAN*H2: o informante 2 tinha 80 anos, viúvo, e estudou até o $4^{\circ}$ ano no grupo escolar. Segundo ele, foi morador na mesma rua desde criança, apenas mudando de casa, aproximando-se mais do centro, após reformas na região. Durante a infância, a localidade onde estava era formada de chácaras e, além da agricultura de subsistência, aproveitava bastante os peixes do rio Tietê.

- SAN*M1: a informante 3 tinha 86 anos, viúva, estudou até o $4^{\circ}$ ano do ensino regular, e explicou detalhadamente como era realizado o ofício no comércio que possuía. Dona de padaria há décadas, contou como eram feitos os processos de produção de pães e como sua padaria centenária foi se modernizando.

- SAN*M2: a informante 4 tinha mais de 80 anos (ela não quis informar a idade exata). Viúva, ela estudou até o $4^{\circ}$ ano, e nos contou sobre a sua infância e juventude vivida inteiramente na cidade: havia sido criada pela tia e fora grande frequentadora de festas e bailes, até casar-se com um funcionário da Light (como era chamada a empresa de energia). 


\subsubsection{Pirapora do Bom Jesus}

A conversa comum entre os informantes foi de como houve a mudança no rio com a chegada da empresa distribuidora de energia, a construção da barragem e suas consequências.

- PP*H1: o informante 1 tinha 74 anos, viúvo, e estudou apenas até o $2^{\circ}$ ano da educação básica, tendo de deixar os estudos para poder trabalhar, já que a mãe havia falecido. Contou como a Central Hidrelétrica Rasgão impactou suas vidas alterando os hábitos dos moradores que envolvia desde mudanças de casas a escassez da exploração de subsistência.

- PP*H2: o informante 2 tinha 67 anos, casado, e era dono de um comércio de doces na região. Fez apenas o ensino básico, até o $4^{\circ}$ ano, e afirmou que houve muitas modificações durante os últimos anos. Segundo ele, as casas eram feitas de pau a pique, "tipo dos indígenas [...] do tempo da povoação".

- PP*M1: a informante 3 tinha 85 anos, viúva, e estudou até o $4^{\text {o }}$ ano. Foi moradora por anos da chamada da parte baixa da cidade, que fica próxima ao rio, mudando-se quando adulta para a alta. Porém, teve várias lembranças da época em que se brincava no rio e das procissões, incluindo as que aconteciam em barcos levando a imagem de Bom Jesus.

- PP*M2 - a informante 4 tinha 81 anos, viúva, tendo estudado até o $3^{\circ}$ ano do ensino básico. Conforme sua entrevista, ela sempre viveu em Pirapora, na rua central, e considera ter tido uma boa infância, embora tivesse mais memórias de seu casamento e marido.

\subsubsection{Itu}

Os entrevistados de Itu contaram com satisfação sobre a infância e juventude em sítios e chácaras, explicando com detalhes como aconteciam as festas na região e as brincadeiras de criança. As mulheres, sobretudo, descreveram como foram os seus namoros, o dia de seus casamentos e a celebração.

- ITU*H1 - o informante 1 tinha 70 anos, viúvo, e estudou até o $4^{\circ}$ ano do ensino básico. Durante sua infância, viveu em um sítio, e na adolescência mudou-se 
para o centro urbano de Itu, trabalhando também como músico em restaurantes e festividades na cidade.

- ITU* $\mathrm{H}_{2}$ - o informante 2 tinha 75 anos, viúvo, e estudou até o $3^{\circ}$ ano do ensino básico. Mudou-se para o centro urbano de Itu na década de 1960, tendo morado toda a sua infância no sítio. Segundo ele, a energia elétrica demorou a chegar, e ele participou de diversas festas de casamento iluminadas por lamparina.

- ITU*M1 - a informante 3 tinha 64 anos, casada, e estudou até o $2^{\circ}$ ano do ensino básico. Tendo começado a trabalhar aos 6 anos, a entrevistada trabalha no mesmo comércio há 38. Ela é moradora de um dos bairros de Itu, e vai ao centro somente para trabalhar.

- ITU*M2 - a informante 4 tinha 64 anos, casada, e estudou até o $4^{\circ}$ ano do ensino básico. Nasceu e cresceu na cidade, morava numa vila quando jovem, a qual ela chamou de rica por alguns moradores possuírem televisão e cobrarem a quem quisesse assistir. Há 20 anos trabalha no comércio de rua.

\subsubsection{Porto Feliz}

Em Porto Feliz, um assunto comum entre todos os entrevistados foi a presença do rio Tietê: sua importância como meio de entretenimento, subsistência, e as festividades do mês de outubro quando os moradores recriam as chegadas dos bandeirantes na época das monções.

- $\mathrm{PF}^{*} \mathrm{H} 1$ - o informante 1 tinha 80 anos, casado, estudou até o $4^{\circ}$ ano do ensino básico, e nunca saiu da região. Quando jovem, morava no centro urbano, e, ao casar-se, mudou para o sítio onde o sogro tinha uma usina, ajudando na lavoura e na distribuição dos itens que produziam.

- $\mathrm{PF}^{*} \mathrm{H} 2$ - o informante 2 tinha 69 anos, casado, estudou até o $4^{\circ}$ ano do ensino básico e foi policial militar durante a juventude. Durante a infância, morava no sítio junto com a família, trabalhava na colheita de cana e a distribuía para as usinas de Porto Feliz. Explicou que, naquela época, só o irmão mais velho estudava, enquanto os demais trabalhavam na lavoura. 
- $\mathrm{PF}^{*} \mathrm{M} 1$ - a informante 3 tinha 64 anos, analfabeta (justificado pela morte precoce da mãe), casada. Viveu toda a sua infância em sítio, onde lavava roupa no rio e tinha técnicas especiais para armazenar comida, e, após o casamento, mudou-se para o centro urbano de Porto Feliz.

- $\mathrm{PF}^{*} \mathrm{M} 2$ - a informante 4 tinha 71 anos, solteira, e estudou até o $4^{\circ}$ ano do ensino básico. Sempre viveu no centro urbano de Porto Feliz, perto da gruta, na mesma casa. Trabalhou na bombonière do cinema, depois foi servente durante muitos anos numa escola da região.

\subsubsection{Piracicaba}

Nessa cidade, embora o rio Piracicaba tenha sido mencionado por todos, o diálogo concentrou-se em suas vidas cotidianas, das dificuldades de acesso a serviços básicos e locomoção de outrora, assim como a convivência em áreas rurais.

- $\mathrm{PC}^{*} \mathrm{H} 1$ - o entrevistado 1 tinha 65 anos, casado, e estudou até o $4^{\circ}$ ano do ensino básico. De família tradicional da cidade, sempre morou no centro urbano, sendo neto de um relojoeiro. Porém, ainda quando criança mudou-se para a rua do Porto, que fica às margens do rio Piracicaba, e de lá nunca saiu.

- $\quad \mathrm{PC} * \mathrm{H} 2$ - o informante 2 tinha 73 anos, casado, e estudou até o $4^{\circ}$ ano do ensino básico. Também morador da rua do Porto, filho de pai seleiro, trabalhou como mecânico geral na Fábrica de Tecidos Arethusina, mais conhecida como Boyes. Aprendeu o serviço dentro da própria fábrica, e não foi trabalhar nas usinas, pois a empresa ficava muito próxima de sua casa.

- $\quad$ PC*M1 - a informante 3 tinha 80 anos, casada, e estudou até o $3^{\circ}$ ano do ensino básico. Na infância, morava em sítio, e começou a trabalhar aos 7/8 anos na roça na colheita de algodão, milho e arroz. Estudou até o $3^{\circ}$ ano, pois moravam longe do centro urbano de Piracicaba e não havia como ter acesso à escola.

- $\quad$ PC*M2 - a informante 4 tinha 84 anos, viúva, e estudou até o $4^{\circ}$ ano do ensino básico. Foi moradora na zona rural até os 32 anos, assim, ela cresceu no sítio, casou-se e continuou morando no campo, só vindo morar no centro urbano após adulta. 


\subsubsection{Capivari}

Os entrevistados estabeleceram, em seus diálogos, um paralelo sobre os dias atuais e os de antigamente, contando como eram as brincadeiras de criança, o namoro, o passeio na praça.

- CAP*H1 - o informante 1 tinha 83 anos, viúvo, e estudou até o $4^{\circ}$ ano do ensino básico. Hoje aposentado, o entrevistado foi caldeireiro na Usina de Rafard, cidade vizinha e emancipada de Capivari na segunda metade do século XX. Morou no sítio durante a infância e se mudou para o centro urbano quando jovem para trabalhar na fábrica.

- CAP*H2 - o informante 2 tinha 97 anos, viúvo, e estudou até o $4^{\circ}$ ano do ensino básico. Nascido e criado na cidade, a única vez que saiu de Capivari foi quando ele participou da Revolução de 32. Disse ter conhecido Amadeu Amaral quando criança, e ter visto Tarsila do Amaral. Foi músico integrante da orquestra municipal da região. Faleceu no início de 2013.

- $\mathrm{CAP}^{*} \mathrm{M} 1$ - a informante 3 tinha 88 anos, viúva, e estudou até o $4^{\circ}$ ano do ensino básico. Foi costureira e sempre morou no centro urbano da cidade. Confessou que gostaria de ter estudado, algo que o pai não deixou por acreditar que mulheres não precisassem estudar.

- $\mathrm{CAP}^{*} \mathrm{M} 2$ - a informante 4 tinha 64 anos, casada, e estudou até o $4^{\circ}$ ano do ensino básico. Disse que não pôde estudar mais, porque os pais priorizavam a educação dos irmãos mais jovens. Contou com saudosismo sobre as brincadeiras e hábitos de criança.

\subsubsection{Tietê}

Em Tietê, em meio às lembranças, todos os informantes foram unânimes em lembrar que os flertes e namoros se davam na praça frente à Igreja Matriz, com o fechamento dela às $22 \mathrm{~h}$ pelo guarda municipal que ordenava a todos para que voltassem para casa.

- TIE*H1 - o informante 1 tinha 64 anos, casado, e estudou até o quarto ano do ensino básico. Morou toda infância e juventude no sítio, e contou boas histórias 
sobre ir até a cidade a cavalo, andar de pés descalços e sobre os namoros da época.

- $\quad \mathrm{TIE}^{*} \mathrm{H} 2$ - o informante 2 tinha 62 anos, solteiro, e estudou até o quarto ano do ensino básico, sempre vivendo no centro urbano de Tietê. Lembrou-se de como brincava com os colegas na rua e na praça central, principalmente pregando peças nos namorados que estavam na praça.

- $\quad$ TIE*M1 - a informante 3 tinha 63 anos, viúva, e estudou até o quarto ano do ensino básico. Durante a infância, viveu no sítio, onde ajudava a mãe nos trabalhos caseiros; e foi morar no centro urbano depois de casada. Ela se lembrou de que, antigamente, na praça havia separação entre negros e brancos, pois os negros não andavam na parte interna do passeio, apenas na rua.

- TIE*M2 - a informante 4 tinha 60 anos, solteira, estudou até o quarto ano do ensino básico, embora dissesse não ter compreendido bem os estudos e não os ter prosseguido por "problemas de cabeça". Durante anos, foi bordadeira, e viveu em algumas residências com seus irmãos.

\subsubsection{Braga}

Durante as entrevistas, foi unânime a opinião dos informantes de que a infância foi árdua, e não guardaram boas memórias desse tempo. Ao contrário das cidades do Médio Tietê, não havia o hábito de se conhecer pessoas em festas ou nas praças: eles se casavam com conhecidos, que eram seus vizinhos ou primos.

- BRAGA*H1 - o informante 1 tinha 78 anos, casado, estudou até a $4^{\text {a }}$ classe, sempre morou em Braga, a não ser no período em que ele fora para a Guerra em Angola. Jogou bastante futebol, inclusive quando estava na tropa, depois trabalhou com ferramentas e se aposentou como motorista de condução escolar.

- BRAGA*H2 - o informante 2 tinha 71 anos, casado, estudou até a $4^{\text {a }}$ classe, morador de uma freguesia de Braga - a 5 minutos do centro histórico. Informou que a infância foi muito sofrida, a ponto de passar necessidades. Conheceu a esposa em uma festa, e a comparou com as festas atuais, sem grandes mudanças. 
- BRAGA*M1 - a informante 3 tinha 84 anos, viúva e analfabeta. Informou que teve uma vida trabalhosa, pois começou a trabalhar muito cedo, motivo pelo qual não pôde estudar. Segundo ela, desde que se pôs em pé, ganhava dinheiro buscando água na fonte para outras famílias mais abastadas, logo, disse não ter tido infância.

- BRAGA*M2 - a informante 4 tinha 70 anos, casada e estudou até a $3^{\mathrm{a}}$ classe. Estudou até os 10 anos e já começou a trabalhar em casa de família, servindo-as. Ela contou que havia brincadeiras de crianças apenas aos finais de semana, após a missa, já que a semana era destinada ao trabalho.

\subsubsection{Bragança}

Em Bragança, a maioria dos informantes foi entrevistada na vila murada do Castelo de Bragança. A conversa comum entre os homens foi como eles passaram sua juventude antes de ir morar próximo ao castelo, enquanto as mulheres contaram sobre sua infância e, uma delas, descreveu as brincadeiras pelas ruas da vila.

- BRAGANÇA*H1 - o informante 1 disse ter mais de 80 anos, viúvo e analfabeto. Ele disse que não frequentou a escola por preferir brincar no rio e nas matas. Foi sapateiro e praça na Guerra em 1945, fazendo parte também da cavalaria.

- BRAGANÇA*H2 - o informante 2 tinha 73 anos, casado, e estudou até a $4^{\text {a }}$ classe. Foi carpinteiro, e, atualmente, é dono de uma taverna. Informou que não teve brincadeiras na infância, pois teve de começar a trabalhar ainda criança. Quando jovem, também esteve na guerra.

- BRAGANÇA*M1 - a informante 3 tinha 72 anos, viúva, e estudou até a $3^{\text {a }}$ classe. Assim como as outras informantes, ela teve de trabalhar desde criança, e disse que a educação era dada apenas aos ricos. Como ela sempre viveu na vila murada, contou que as festas eram feitas nas ruas, assim como as brincadeiras de crianças.

- BRAGANÇA*M2 - a informante 4 tinha 72 anos, viúva, e estudou até a $3^{\text {a }}$ classe. Trabalhou bastante quando criança, e, depois, na lavoura, fazendo 
serviços ensinados pelo pai. Quando jovem, viveu na aldeia, onde conheceu o marido e se casou.

\subsubsection{Vila Real}

$\mathrm{O}$ assunto mais discorrido entre os entrevistados foi a guerra. $\mathrm{O}$ informante de Parada do Pinhão descreveu as más condições dos campos de guerra, e as mulheres relataram o sofrimento do mesmo período por não receberem notícias sistemáticas de seus familiares.

- VREAL*H1 - o informante 1 tinha 64 anos, solteiro, e estudou até a $4^{\mathrm{a}}$ classe. Morador de Parada do Pinhão, trabalhava no campo e, quando jovem, esteve na Guerra de Independência, lutando em Moçambique. Ele contou o quanto sofreu no exército, passando fome e sede.

- VREAL*H2 - o informante 2 tinha 82 anos, casado, artesão, e morador de uma freguesia de Vila Real, tendo estudado até a $4^{\text {a }}$ classe. Após ter se formado, o pai ensinou-lhe a trabalhar com a terra preta para a produção de artesanato. Embora tenha servido o exército, não chegou a lutar na Guerra.

- VREAL*M1 - a informante 3 tinha 78 anos, solteira, também moradora de Parada do Pinhão, estudou até a $3^{a}$ classe. Contou que os irmãos mais velhos vendiam peixe, nunca passara necessidade, mas acentuou a dificuldade que havia para estudarem quando crianças.

- VREAL*M2 - a informante 4 tinha 60 anos, casada, moradora da Parada do Pinhão, e estudou até a $3^{\mathrm{a}}$ classe. Também reclamou que começara a trabalhar muito cedo, sequer se lembrando de sua infância. Nos tempos de estudos, lembrou-se de que havia muitas trocas de professoras na escola.

\section{Seleção dos controles para comparação da entoação caipira}

Dentro dos estudos de estatística, o controle estatístico de processo é uma técnica aplicada à produção que permite comparar um elemento ideal à realidade que se possui (RIBEIRO, CATEN, 2012, p.5). Ou seja, essa prática consiste em contrapor um valor ideal com os valores obtidos dentro de uma realidade, para que, por meio do 
reconhecimento das variáveis, se possam identificar e corrigir possíveis erros administrativos. Nesta tese, o controle será utilizado para comparar e identificar as diferenças entre o dialeto caipira e o chamado português-padrão utilizado nos meios televisivos.

Para essa pesquisa, foram selecionadas 20 gravações de apresentadores de telejornais da TV Rede Globo, para servirem como controle, por possuírem a chamada "fala neutra" característica e trabalhada pelos apresentadores de telejornais (BARBOSA, 2002, p.36).

Segundo Ribeiro (2004, p.123), a uniformidade da fala pelos apresentadores e jornalistas nasceu da necessidade de "minimizar as distorções entre diferentes regiões do Brasil e criar um padrão de qualidade no telejornalismo de todas as emissoras da Rede Globo". Ainda segundo a autora, por meio do Congresso Brasileiro de Língua Falada no Teatro de 1956, ocorrido em Salvador, decidiu-se definir um padrão nacional, "no qual ficou acertado que a pronúncia-padrão do português falado no Brasil seria a do Rio de Janeiro, com algumas restrições. Os 'esses', não poderiam ser muito sibilantes e os 'erres' não poderiam ser muito arranhados, guturais".

Por isso, estabeleceu-se como critério a comparação do dialeto caipira desenvolvido no Médio Tietê e de Portugal com o uniformizado pela rede televisiva, tendo em vista seu trabalho de padronização de pronúncias.

\subsection{Processo de coleta}

Os controles foram selecionados a partir de gravações de telejornais disponibilizados pelo site YouTube. Especificamente, deu-se preferência ao programa SPTV da Rede Globo, por ser a atração destinada à cidade de São Paulo. Assim como as amostras do Médio Tietê, as 20 frases coletadas tinham cerca de 15 a 20 segundos de duração. Mesmo sendo um programa televisivo com um roteiro a ser seguido, procuraram-se momentos de espontaneidade nas entrevistas dos jornalistas com outras pessoas. Consoante Barbosa (2002), "a fala espontânea pode se dar em diversos gêneros enunciativos ou discursivos".

Após escolhido, por meio de outro aplicativo disponibilizado no site Video2mp3 (acessível em www.video2mp3.net), separou-se o áudio do vídeo e, com ele, deu-se todo o tratamento também feito com as entrevistas do Médio Tietê. Ou seja, a gravação foi editada pelo programa Audacity 1.3.12 Beta (Unicode); a análise e a conversão da curva de frequência fundamental e da curva de intensidade para arquivos de texto foram realizadas pelo software Speech Filing System (HUCKVALE, 2008); e os valores 
gerados por ele foram analisados pelo aplicativo ExProsodia (FERREIRA-NETTO, 2010).

\section{O estudo de prosódia e a geração de dados pelo ExProsódia ${ }^{\circledR}$}

Os estudos de prosódia tiveram como base a teoria prescrita de Troubetzkoy (1964 [1939]), em que se constata que se é possível verificar a entoação da fala por meio da função direta das variações globais de frequência de $\mathrm{f}_{0}$.

Tendo essa teoria retomada e desenvolvida por outros autores (LIEBERMAN, 1967; MAEDA, 1976; PIERREHUMBERT, 1979; T'HART et al., 1990; VAISSIÈRE, 1997; 2002; XU, 1997 dentre outros), Ferreira Netto (2006; 2008), através do princípio de $\mathrm{Xu}$ e Wang (1997) ${ }^{12}$, entende que a entoação da fala pode se decompor em componentes estruturadoras e semântico-funcionais: finalização (F) e sustentação (S), de um lado, foco/ênfase (E) e acento lexical (A). Assim, é possível analisar a língua com recursos automáticos, sem percepções intuitivas, considerando a hipótese de $\mathrm{f}_{0}$ como uma série temporal a partir do uso do aplicativo ExProsodia ${ }^{13}$. Segundo os autores Ferreira Netto, Consoni e Peres (2011), "a decomposição da onda sonora portadora da fala parte da definição de seu tom médio como forma prototípica, para a qual convergem todas as frequências próximas", e, analisando-a, é possível estabelecer um "parâmetro de comparação inicial para todas as demais formas que venham a ser percebidas".

De acordo com os autores, o aplicativo considera o tom médio por ser forma prototípica, conforme proposto por Kuhl et alii (2001) definindo o modelo perceptual magnet effect (PME). Nesse modelo, entende-se que a forma prototípica é adquirida na primeira infância, sendo elemento atrator dos demais estímulos.

Juntando essa consideração do TM ao propósito da pesquisa, procurou-se entender a formação do DC observando fontes mais antigas, as quais estão presentes em pessoas mais idosas e de baixa escolaridade. Logo, o estudo da entoação como série temporal dá-se pela observação das ondas sonoras e da conversão delas em números, o que quantifica e concretiza os dados sobre a fala. Com a geração de dados, viabiliza-se a análise dos dialetos, como será analisado no capítulo 3.

\footnotetext{
12 Segundos os autores, alguns fatos prosódicos decorrem de restrições mecânico-fisiológicas e outros decorrem das necessidades expressivas dos falantes.

${ }^{13} \mathrm{O}$ aplicativo ExProsodia está registrado no INPI, pela Universidade de São Paulo, sob número 08992-2, conforme publicação no RPI 1974, em 04/11/2008. ExProsodia - Análise automática da entoação na Língua Portuguesa (FERREIRA NETTO, 2008, p. 2 de 13).
} 


\subsection{Considerando a hipótese $F_{0}$ como série temporal}

Nos estudos de estatística, a série temporal é utilizada como uma forma de previsão para dados processos, como vendas, políticas econômicas, etc. Essa prática nasceu a partir da oportunidade de mensuração do tempo, podendo-se "estabelecer algumas relações entre a passagem do tempo e a ocorrência de fenômenos biológicos" (GARBER, 1995, p.92). Segundo o autor, "ao observarmos um fenômeno (variável) na natureza, podemos perceber que este é estimulado por uma infinidade de outros fenômenos (variáveis) correlacionados a ele, uns com uma interferência maior e outros com menor".

O principal objeto de observação da série temporal é justamente o tempo. Para a análise de determinados informações, as variáveis que estão presentes nele irão compor a projeção de dados por meio de uma fórmula matemática capaz de identificar um parâmetro dentro do fenômeno desenvolvido. Assim sendo, fica preestabelecido que (GARBER, 1995, p.95):

$\mathrm{Z}_{\mathrm{t}}$ - valor observado da ST no momento $\mathrm{t}$

$\mathrm{h}$ - horizonte da projeção (número de passos a ser projetado)

$\hat{Z}$ (h) - projeção feita no ponto de projeção t para o horizonte $h$

$\hat{Z}_{t}-$ projeção para o momento $t$ feita no momento anterior, o mesmo que $\hat{Z}_{t-1}(1)$

$\varepsilon_{\mathrm{t}}$ - variável aleatória que representa o erro de projeção do momento, supondo ainda que tem média 0 e variância constante $\sigma^{2}$

Com a generalização do modelo como: $\mathrm{Z}_{\mathrm{t}}=\mathrm{f}\left(\mathrm{Z}_{\mathrm{t}-1 ;} \mathrm{Z}_{\mathrm{t}-2 ;} \mathrm{Z}_{\left.\mathrm{t}-3 ; \ldots ; \mathrm{Z}_{1}\right)}\right)+\varepsilon_{\mathrm{t}}$. $\mathrm{Ou} \mathrm{Z} \mathrm{Z}_{\mathrm{t}}=\hat{\mathrm{Z}}_{\mathrm{t}-1}(1)+\varepsilon_{\mathrm{t}}$

Por a série temporal prescrever um hábito, um costume, algo que tende a se repetir sempre, o uso do cálculo aqui explicado é trazido para os estudos de prosódia: as fórmulas utilizadas para prescrever situações distintas dentro da projeção de uma venda, por exemplo, podem também ser usadas para quantificar as ocorrências orais. Desta forma, Ferreira Netto (2008) fez a correlação dessa teoria com as observações ora apresentadas pelos autores especialistas em entoação e determinou que "o valor $\mathrm{Z}$ obtido no momento $\mathrm{t}$ - notado como $\mathrm{Z}_{\mathrm{t}}$ - é a soma dos componentes que concorreram para o seu estabelecimento. Os momentos encontram-se nos núcleos silábicos que ocorrem em intervalos cuja regularidade é predominante, mas não absoluta" (PERES, CONSONI, FERREIRA NETTO, 2011).

A decomposição de $\mathrm{f}_{0}$ em quatro elementos (sustentação, finalização, foco/ênfase e acento lexical) desenvolve o tom médio ideal (TM), conforme pode ser visto no gráfico desenvolvido pelos autores para a projeção da fala: 


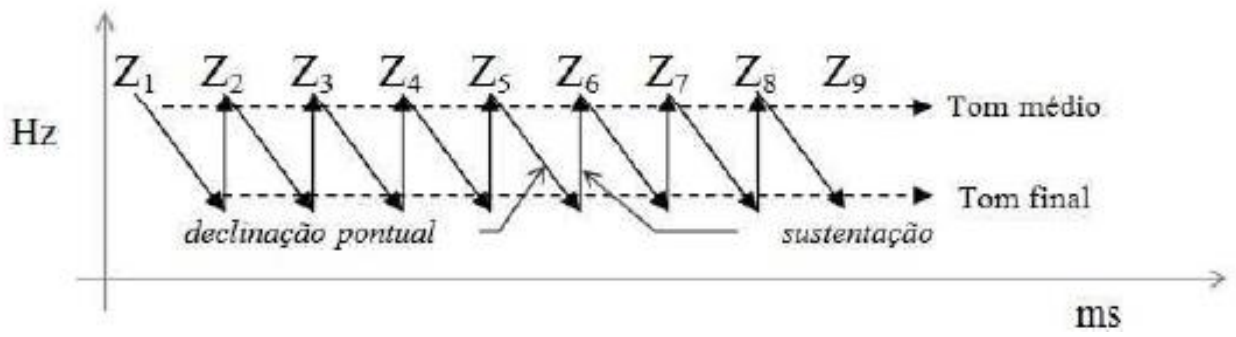

Gráfico 1: No gráfico, as setas diagonais escuras representam a declinação desencadeada em cada momento pelo desejo de supressão do esforço e as setas verticais escuras representam a sustentação desencadeada pela retomada da tensão inicial, ambas formando o ritmo tonal (FERREIRA et al., 2011).

Ainda de acordo com o autores, a finalização é "o tom-alvo da declinação pontual, estabelecida por um intervalo ideal decrescente de 7 semitons (st) do tom médio (TM) obtido até o momento $\mathrm{Z}_{\mathrm{t}}$ ". Para a geração de dados pelo ExProsodia (PERES, CONSONI, FERREIRA NETTO, 2011), é considerada a fórmula $Z_{t}=S_{t}+F_{t}$ $+\mathrm{E}_{\mathrm{t}}\left(+\mathrm{A}_{\mathrm{t}}\right)$, entendendo-se:

- $\mathrm{Z}_{\mathrm{t}}$ continua sendo o valor observado da série temporal (ST) no momento $t$, sendo que decomposição dos momentos $\mathrm{Z}_{\mathrm{t}}$ é feito com a subtração do $\mathrm{TM}_{\mathrm{t}}-1$;

- $\quad$ o $S_{t}$ é a sustentação, definido pela extração de $F_{t}$ e $E_{t}$ de $Z_{t}$, ou de 7 st de $T_{\mathrm{t}}-1$;

- o $\mathrm{F}_{\mathrm{t}}$ é a finalização, obtida pelo cálculo $\mathrm{TM}_{\mathrm{t}}-1-7 \mathrm{st}$. Lembrando que, segundo Ferreira Netto e Consoni (2008), 7 st é o intervalo ideal decrescente do tom médio;

- $o E_{t}$ considera-se o foco/ênfase: para definir $E_{t} \operatorname{com} Z_{t}$ maior do que $\mathrm{TM}_{t}-1$, extrai-se $\mathrm{TM}_{\mathrm{t}}-1+3$ st de $\mathrm{Z}_{\mathrm{t}}-1$; porém, no caso de se definir $\mathrm{Z}_{\mathrm{t}}$ menor do que $\mathrm{TM}_{\mathrm{t}}-1$ extrai-se $\mathrm{F}_{\mathrm{t}}-1-4$ st de $\mathrm{Z}_{\mathrm{t}}-1$;

- e o $\mathrm{A}_{\mathrm{t}}$ é o acento lexical.

Os valores obtidos para os cálculos da entoação estão em Hertz $(\mathrm{Hz})$ e em milissegundos (ms), com intervalos de aproximadamente $1 / 2$ semitom. Conforme os autores (PERES, CONSONI, FERREIRA NETTO, 2011), "na medida em que a rotina ExProsodia faz a decomposição de $\mathrm{f}_{0}$ em suas componentes de TM, F e S, é possível fazer a síntese da entoação da frase a partir de qualquer uma delas, bem como a geração de um arquivo sonoro."

Em relação aos tons, Ferreira Netto et al. (2008) observa que são percebidas no português brasileiro $(\mathrm{PB})$ variações ascendentes iguais superiores a 3 semitons e descendentes iguais ou superiores a 4 semitons. 


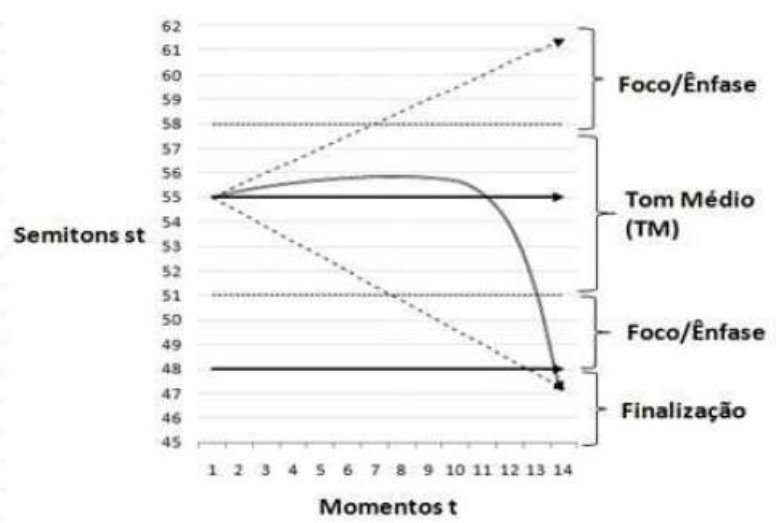

Gráfico 2: Os traços contínuos mais escuros mostram o TM e a Finalização. Os traços pontilhados mostram os limites acima, de 3 st, e abaixo, de 4 st, do TM. A escala horizontal mostra os valores em MIDI, referindo os graus da escala cromática diatônica ocidental. A linha curva no centro mostra a tendência à finalização da frase, e as linhas diagonais apontam para Foco/ênfase e para a finalização (FERREIRA et al., 2011).

A figura anterior demonstra visualmente como se dá a formação do momento $t$ da série temporal para o estudo da entoação.

\subsection{Utilizando o teste ANOVA para percepção das diferenças dialetais}

Para obter-se um resultado, o aplicativo ExProsodia resgata todos os dados de ocorrência das variações e calcula uma média do objeto analisado. Como esta pesquisa trata das variações dentro do DC em comparação a uma fala neutra, e, após, ao dialeto do norte de Portugal, as informações tidas de cada informante do Médio Tietê e das cidades portuguesas foram agrupadas e calculou-se uma média. Assim, foi utilizado o teste ANOVA de estatística para se estabelecer se há e quais são as diferenças entre os dialetos, verificando se essas estas são significativas.

Para tanto, utilizou-se o teste de Análise de Variância (ANOVA - do inglês Analysis of Variance) que serve para comparar uma variável contínua em contraposição a variável de duas ou mais categorias. Dentro das subdivisões do ANOVA, fez-se uso dos testes $t, f$, de Dunnett e $\chi^{2}$ para examinar as hipóteses. O teste $t$, especificamente, compara as médias entre variáveis; o $f$, as variâncias; o Dunnett compara as diferenças entre as variáves; e o $\chi^{2}$ nos diz em que medida os valores observados se desviam do valor esperado (controle), caso as duas variáveis não estejam correlacionadas. Para a produção das fórmulas e cálculos, utilizou-se o programa Excel e o KyPlot 2.0 beta.

\subsection{A finalização autêntica e a plagal}

Após a geração dos testes, são observados como são dadas as finalizações: se autênticas ou plagais. Essas noções são explicadas por Ferreira Netto (2010) ao notar-se que, no estudo de entoação, havia semelhança tonal entre a finalização de canções 
primitivas e as falas de pessoas de baixa escolaridade, cujos resultados de análise aparecem nas teses de Costa e Baz (ambas de 2011). Vejamos a seguir como se dão esses procedimentos.

\subsubsection{A música e os estudos de prosódia}

Os termos finalização plagal e autêntica são advindos da Teoria Musical, e isso se deve porque, segundo Medeiros (2006), os estudos em fonologia iniciaram-se tardiamente, propiciando à Linguística que fizesse uso de elementos e terminologias musicais para caracterização de dados prosódicos, já que tanto a música quanto a fala apresentam elementos em comum.

Embora em 1779 Steele apontasse que a fala e a música se desenvolvessem em sistemas de escalas e ritmos, e, em 1890, Spencer reconhecesse que tons de voz e cadências expressam emoções na fala - sendo o conjunto das manifestações emotivas o formador da raiz da música - , somente na segunda metade do século XX é que os estudos de prosódia começaram a ter atenção maior sob esse ponto de vista (MEDEIROS, 2006). Dentro desse princípio, as pesquisas de Pierrehumbert e Beckman (1980) demonstram tais similaridades entre fala e música ao utilizarem instrumentos musicais como auxílio para observarem a altura e o ritmo da fala.

Sobre o assunto, Cagliari (2007, p.159-160) informa que "a música mais antiga era intimamente ligada à língua falada", visto que, primeiramente, conforme é registrado em cânticos gregorianos e em músicas gregas e latinas, o canto era mais "plano", ou seja, não há medida como compasso, enquanto a atual é mensurada.

Considerando a tese de Carmo Jr. (2007, p.44), música e fala possuem os domínios sonoros da altura, duração, intensidade e do timbre como categoria, sendo "uma quase-música do sistema verbal, assim como a nota musical é uma quase-sílaba do sistema musical." Sendo assim, sob a mesma noção de Spencer, Carmo Jr. (2007, p. 73) entende que tanto a prosódia quanto a música possuem elementos em sua composição capazes de produzir melodias, e, para tanto, chama as notas musicais de células rítmicas, explicando que o ritmo é dado pelo contraste dessas células, as quais classificam-se como [+forte] / [+longo] e as [-forte] / [-longo], tal qual ocorre na fala. Estabelecendo um paralelo entre os dois, segundo o autor, "a sílaba é uma cadeia da expressão que compreende apenas um único acento", possuindo um fonema central (geralmente uma vogal, chamado de funtivo pressuposto) e outros fonemas periféricos (na maioria das vezes, consoantes, denominado de funtivo pressuponente), fazendo com que haja centros de força conforme a fala é executada. Tal premissa já era ponderada 
por Pike (1945) e Bolinger (1964), os quais avaliam a variação de pitch produzida durante a entoação de uma fala. No estudo da entoação da língua inglesa, Pike considera quatro níveis de contraste: H (high), E (extra high), M (mid) e L (low). Bolinger, por sua vez, no da língua espanhola considera duas: (H) high e L (low).

Carmo Jr. (2007), estabelecendo parâmetros entre música e prosódia, considera que "uma célula rítmica pode ser descrita nos mesmos moldes", desta forma, de sua combinação constrói-se a melodia tonal. As mudanças de nuances entre os tons (separados na tabela por graus) são observadas como "transformações [distensão $\rightarrow$ tensão] e [tensão $\rightarrow$ distensão]”. Os acordes de V grau (ré, sol, si) são dominantes, logo, tensos; enquanto os de I grau (dó, mi, sol) são tônicos e distensos.

Desse processo, organizam-se os acordes, os quais podem ser reconhecidos em uma tabela diatônica de dó maior:

\begin{tabular}{|c|c|c|c|c|c|c|}
\hline DÓ & RÉ & MI & FÁ & SOL & LÁ & SI \\
\hline $1^{\circ}$ grau & $2^{\circ}$ grau & $3^{\circ}$ grau & $4^{\circ}$ grau & $5^{\circ}$ grau & $6^{\circ}$ grau & $7^{\circ}$ grau \\
\hline I & II & III & IV & V & VI & VII \\
\hline
\end{tabular}

Tabela 1: tabela diatônica de dó maior

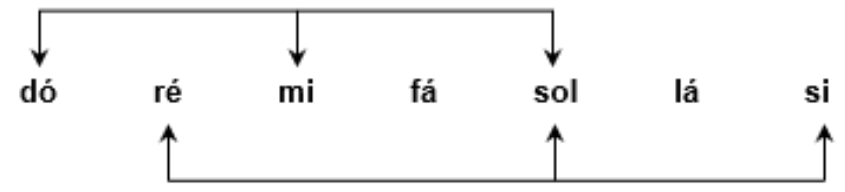

Figura 29: combinação de acordes em dó e sol

Desta forma, compreende-se que a cadência é uma inflexão que ocorre na harmonia. Consoante Carmo Jr. (2007, p.93), as inflexões associam-se "à tensão correlata à marcha harmônica $[\mathrm{I} \rightarrow \mathrm{V}]$ e ao relaxamento correlato à marcha harmônica $[\mathrm{V} \rightarrow \mathrm{I}]$. Livros didáticos de música associam justamente a cadência às pausas que são introduzidas no discurso. Ou seja, as cadências são demarcadores da cadeia".

Buscando ainda a teoria musical, há quatro tipos de cadências (LIMA, 2010):

- a autêntica: ocorre quando o V grau encerra-se em I, e tem caráter conclusivo de final de período, de frase, da música;

- a suspensiva ou semicadência: marca os finais das frases sob a harmonia da dominante, encerrando-se em I-V, II-V, IV-V;

- a de engano: gera certa suspensão e necessita de continuidade no discurso musical, ocorrendo de V-IV;

- e a plagal: acontece quando o IV grau resolve no I. Embora também seja conclusiva, não é realizada de forma acentuada. 


\subsubsection{As finalizações plagais no dialeto caipira e na fala dos portugueses}

Apropriando-se desse conhecimento, Ferreira Netto (2010) compreende que, em finalizações autênticas, a tônica fica no extremo de uma escala, enquanto em plagais é encontrada no centro da escala ou próximo dela.

Pelos estudos apresentados por Baz e Costa (ambos de 2011), percebe-se que o traço plagal está relacionado à fala de pessoas com baixa escolaridade ou analfabetos. Baz (2011) verifica em sua tese sobre a entoação dos índios paraguaios que os processos de finalização de suas músicas e de sua fala são predominantemente plagais. Costa (2011), por sua vez, analisou senhoras corumbaenses e índias guatós com idades superiores a 40 anos, semianalfabetas e analfabetas, e outro grupo de moças alfabetizadas. O resultado demonstrou que tanto as índias quanto as senhoras apresentavam a finalização plagal, enquanto as meninas traziam a autêntica.

De modo que se compreenda a diferença entre ambas as finalizações, Baz (2011, p.28) exemplifica tal noção com as apresentações dos gráficos produzidos por Ferreira Netto (2010), as quais serão reproduzidas abaixo.
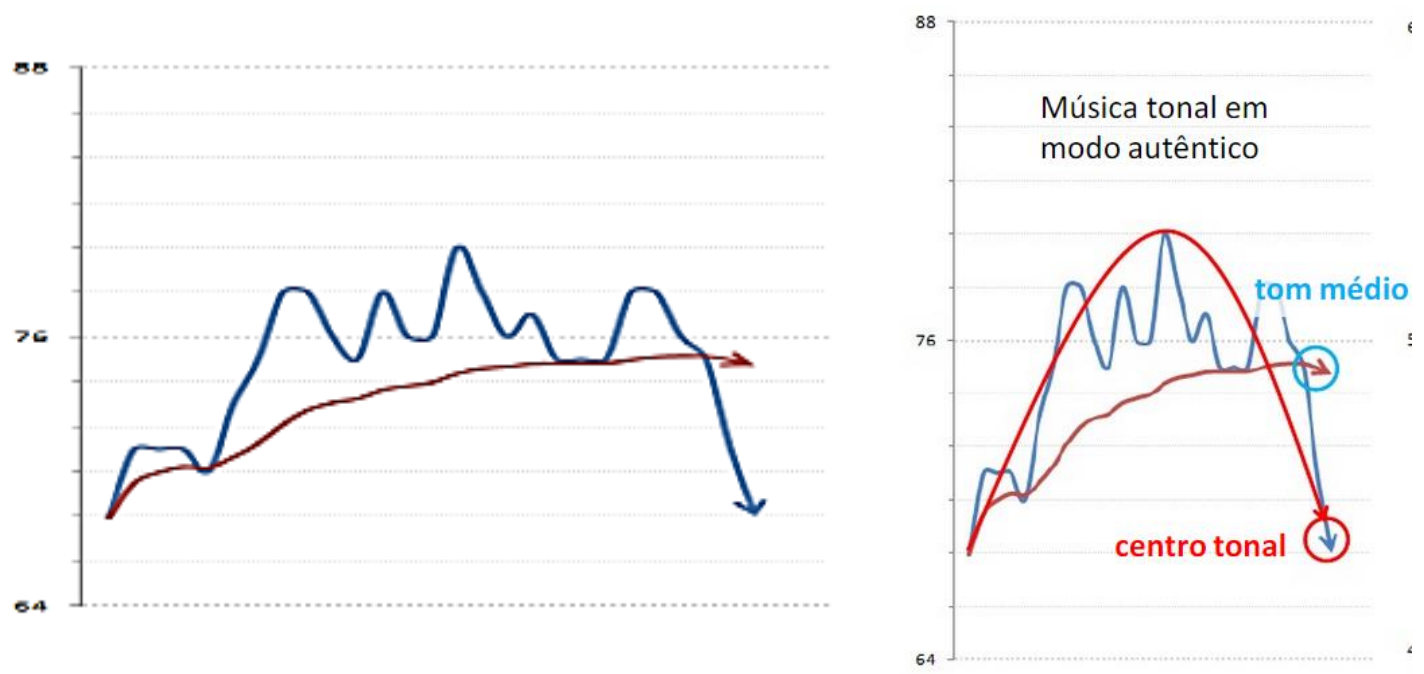

Gráfico 3: caracterização do processo de entoação do gênero musical Fandango Paulista, de Rossini Tavares de Lima, da obra Folclore de São Paulo, 1954 (FERREIRA NETTO, 2010)

Primeiramente, vemos um exemplo de finalização autêntica. A linha vermelha indica o tom médio, enquanto a azul mostra o desenho melódico da canção. Nele, notase a finalização acentuada diminuindo em três tons em relação ao traço correspondente ao tom médio, diferentemente do que ocorre no gráfico 2 . 

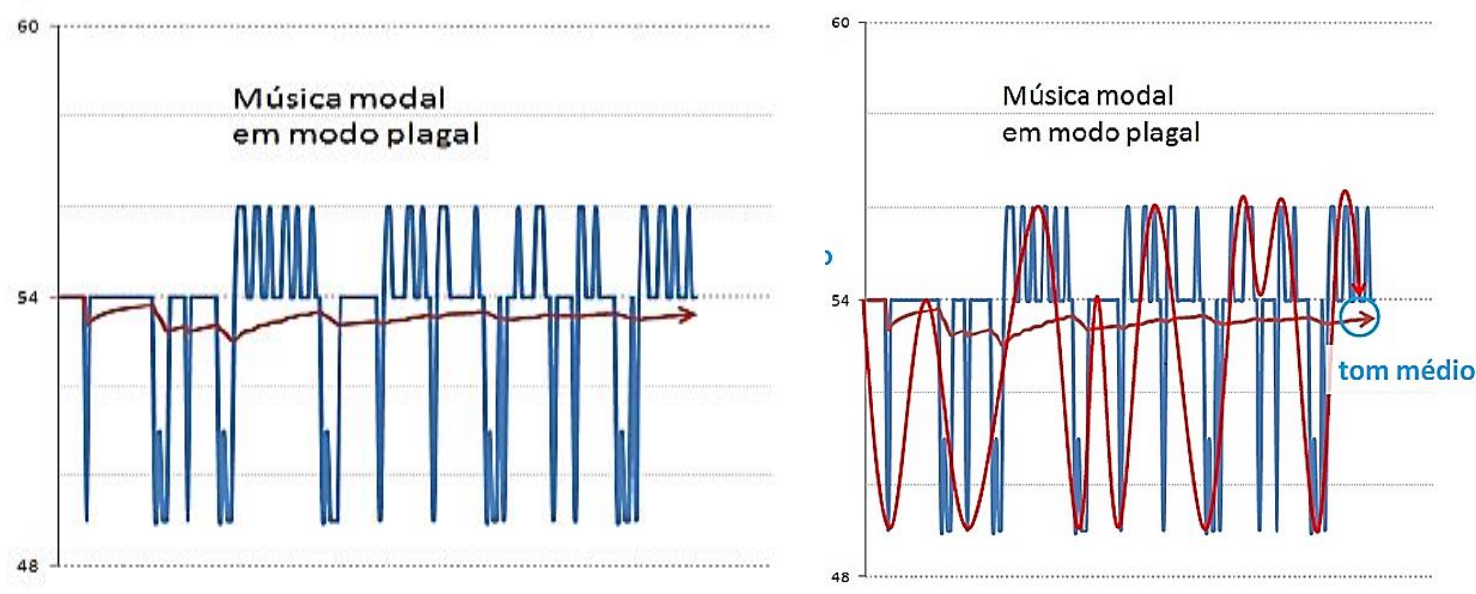

Gráfico 4: caracterização do processo de entoação de uma música da tribo Kaiowá, retirada da obra de Helza Camêu, Introdução ao estudo da música indígena brasileira, 1977 (FERREIRA NETTO, 2010)

Nessas representações, temos a exemplificação de uma finalização plagal em que se analisou uma música da tribo Kaiowá. Nelas, percebemos a definição do autor quanto ao modo plagal caracterizar-se por ser uma variação em torno do tom central. Percebe-se que a finalização encerra-se em conjunto com o tom médio, não havendo diferenças de tons entre eles.

De modo bastante semelhante, os resultados das análises dos informantes do Médio Tietê e Portugal seguem o exemplificado no gráfico 12, ou seja, os entrevistados trouxeram a caracterização do traço plagal em suas falas, confirmando a tese de que a escolarização é capaz de mudar a prosódia de seus falantes, conforme veremos nos capítulos a seguir. 


\section{CAPÍTULO 3}

A entoação caipira 


\section{A entoação caipira}

Sabe-se que a prosódia é um conjunto de ações que envolvem ritmo, duração, e intensidade, formados pela entoação. Logo, tendo em vista a extensão de estudos que ainda necessitam ser produzidos sobre a prosódia caipira, esta tese buscará primeiramente como ocorre a entoação por ser o princípio básico para as pesquisas sobre a linguagem oral, que, segundo Steele (1759, p.b2), é estabelecida por meio de variações tonais: "in pronunciation, the voice moved up and down by such small gradations as that, whether the degrees were by quarters of a diatonic tone, or by smaller divisions, they seemed, in comparison with those of our chromatic-diatonic, to be by imperceptible slides" ${ }^{\prime 14}$. Considerando estudos mais atuais, Ferreira Netto e Baz (2011, p.1) corroboram essa visão, correlacionando a ação entoacional com sua formação biológica quando observam que as "microvariações tonais também decorrem do processo de manutenção da fala, na medida em que a articulação da voz necessita de um controle constante dos movimentos das pregas vocálicas [...]".

Sabendo-se disso, é possível analisar a entoação examinando as ondas sonoras produzidas pelas falas, para, então, verificarmos o $\mathrm{f}_{0}$ e decompô-lo para análises individuais de frequência e intensidade em função de tempo por meio de dados gerados pelo ExProsodia (FERREIRA NETTO, 2008), conforme explicado no capítulo 2.

Após testes preliminares, a pesquisa concentrou-se na avaliação do tom médio e tom final, pois esses elementos apresentaram distinção e resultados relevantes, os quais serão vistos a seguir.

\section{Objetos de análise: tom médio e tom final}

De acordo com Ferreira Netto e Martins (2010, p. 287-288), os falantes têm em comum uma normatização inconsciente do tom utilizado. Segundo os autores,

[...] os falantes teriam a tendência a estabelecer um tom fundamental, no início da fonação, de modo que durante o processo de produção da fala, o mesmo falante estaria a todo o momento tentando ajustar as alturas de sua frequência fundamental $\left(\mathrm{F}_{0}\right)$ como forma de manter-se neste patamar previamente estabelecido. Nesse sentido as variações pertinentes seriam compreendidas pelo ouvinte como marcas estruturais ou marcas semânticas.

Ferreira Netto (2006) ainda propõe que a manutenção do tom do falante seja de seu conhecimento. Assim sendo, há um tom médio (TM) - "estabelecido pela

\footnotetext{
${ }^{14}$ Tradução livre: "na pronúncia, a voz move-se para cima e para baixo em pequenas gradações tais que, se os graus fossem um quarto de um tom diatônico, ou por divisões menores, eles pareceriam lâminas imperceptíveis, em comparação com as de nossa cromática-diatônica".
} 
sustentação do alvo do movimento rítmico tonal durante a produção da fala" (FERREIRA NETTO; BAZ, 2011, p.2) - usado como ponto de partida para a decomposição da série temporal de $\mathrm{F}_{0}$. Como já comentado anteriormente, decompõe-se o $\mathrm{F}_{0}$ em componentes estruturadores (finalização e sustentação) e semântico-funcionais (foco/ênfase, acento lexical).

A finalização tonal, prevista por Maeda (1976) e definida como baseline por Cohen e T'Hart (1967) e Pierrehumbert (1980), consiste na existência da queda gradual de $\mathrm{F}_{0}$.

Sabendo-se que os tons sofrem variações conforme as necessidades de seu falante, constatou-se que a finalização dada em língua portuguesa possui tom abaixo do tom médio (FALÉ, I.; FARIA, 2006; MORAES, 2007; COSTA, 2009, 2011), como também será observado nas análises a seguir.

\subsection{O tom médio}

Para se obter o TM dessas frases, foi utilizado o método de detecção automática das sílabas, chamado de c.p.s. (candidato a pico silábico) pela média. Calculado pelo ExProsodia, a estimativa da média do TM faz-se pela coleta geral de dados gerados e enviados pelo programa Speech Filing System. Com os valores divididos em milissegundos, tem-se uma sequência a qual é possível analisar por meio das fórmulas estatísticas, para, assim, determinar a média estabelecida pelo $\mathrm{F}_{0}$ e intensidade. Sobre essa geração de dados, Vassoler e Martins (2013, p. 13) explicam que o método analisa a frequência fundamental e intensidade a cada 5 milissegundos, gerando a unidade entoacional com valores determinados pelo analista e maiores que zero num período superior a 20 milissegundos. Com os parâmetros postos, os valores de $\mathrm{F}_{0}$ são calculados a partir de testes de hipótese, de modo que se eliminem grandes variações ${ }^{15} \mathrm{e}$, desta forma, obtêm-se dois tipos de análise $\left(i d\right.$.): "a primeira mapeia os valores de $\mathrm{F}_{0}$ (as unidades entoacionais), em busca de valores válidos, ao passo que a segunda analisa a constância de tais dados. O parâmetro de constância é sempre a média, valores muito distantes da média são excluídos".

Realizada essa rotina, originaram-se os valores tidos na tabela a seguir.

\footnotetext{
${ }^{15}$ Nos estudos estatísticos, variações esporádicas ocorrem fora dos limites de uma curva modal (esse elemento sintetiza os processos que acontecem com mais frequência); logo, como são exceções, não são consideradas.
} 


\begin{tabular}{|c|c|c|c|c|c|c|c|c|c|c|c|}
\hline TM cps & CAP & ITU & PC & PP & PF & SANT & TIE & BRAGA & BGÇ & VR & CONTR \\
\hline H1/FR1 & 118 & 173 & 181 & 113 & 179 & 178 & 158 & 133 & 155 & 146 & 142 \\
\hline H1/FR2 & 134 & 153 & 179 & 133 & 170 & 170 & 194 & 156 & 179 & 145 & 121 \\
\hline H1/FR3 & 133 & 172 & 178 & 116 & 169 & 163 & 171 & 143 & 143 & 128 & 157 \\
\hline H1/FR4 & 158 & 176 & 176 & 133 & 141 & 164 & 133 & 167 & 185 & 148 & 109 \\
\hline H1/FR5 & 145 & 173 & 180 & 128 & & 71 & 159 & 172 & 152 & 148 & 170 \\
\hline H2/FR1 & 146 & 160 & 173 & 129 & 150 & 110 & 143 & 175 & 156 & 171 & 144 \\
\hline H2/FR2 & 137 & 169 & 175 & 132 & 169 & & 177 & 193 & 169 & 181 & 132 \\
\hline H2/FR3 & 145 & 156 & 176 & 139 & 152 & 114 & 151 & 192 & 174 & 184 & 140 \\
\hline H2/FR4 & 141 & 170 & 179 & & 156 & & 200 & 66 & 140 & 177 & 132 \\
\hline H2/FR5 & 133 & 170 & 181 & 130 & 154 & 126 & 161 & 266 & 151 & 162 & 130 \\
\hline M1/FR1 & 179 & 132 & 157 & 219 & 187 & 187 & 185 & 255 & 188 & 189 & 224 \\
\hline M1/FR2 & 130 & 237 & 199 & 217 & 182 & 195 & 204 & 228 & 194 & 188 & 257 \\
\hline M1/FR3 & 156 & 235 & 206 & 235 & 194 & 236 & 202 & 220 & 196 & 243 & 258 \\
\hline M1/FR4 & 182 & 235 & 203 & 218 & 180 & & 202 & 210 & 213 & 215 & 247 \\
\hline M1/FR5 & 156 & 229 & 204 & 184 & 182 & 203 & 180 & 208 & 192 & 199 & 231 \\
\hline M2/FR1 & 196 & 219 & 170 & 165 & 238 & 223 & 209 & 200 & 208 & 196 & 250 \\
\hline M2/FR2 & 168 & 204 & 159 & 158 & 246 & 211 & 255 & 205 & 209 & 224 & 273 \\
\hline M2/FR3 & 180 & 181 & 149 & 185 & 211 & 283 & 266 & 210 & 219 & 232 & 249 \\
\hline M2/FR4 & 197 & 163 & 177 & 188 & 226 & 227 & 241 & 210 & 252 & 217 & 248 \\
\hline M2/FR5 & 189 & 190 & 155 & 162 & 220 & 231 & 241 & 215 & 210 & 209 & 196 \\
\hline
\end{tabular}

Tabela 2: comparação do Tom Médio (TM) em unidade cps medido em Hertz entre as cidades do Médio Tietê, Portugal e o controle

A tabela é composta por 11 colunas verticais constando as cidades Capivari (CAP), Itu (ITU), Piracicaba (PC), Pirapora do Bom Jesus (PP), Porto Feliz (PF), Santana de Parnaíba (SANT), Tietê (TIE), Braga, Bragança (BGÇ), Vila Real (VR) e o controle (CONTR). Nas colunas horizontais, foram colocadas as frases, sendo cinco para cada informante. O H e o M referem-se ao sexo (homem e mulher), a numeração é dada aos entrevistados 1 e 2 de cada sexo, e FR é a abreviatura de "frase". As cores branca, cinza, bege e laranja auxiliam na visualização das linhas de cada informante e suas frases.

Após alcançados os valores mencionados nas tabelas e gráficos que veremos a seguir por meio dessa rotina, foi realizado o teste Anova (fator único) comparando todas as cidades estudadas. Esse teste permite distinguir diferentes populações uma das outras, comparando as colunas e os valores internos de cada coluna entre si.

\begin{tabular}{llrllll}
\hline Fonte da variação & $S Q$ & gl & MQ & F & valor-P & F crítico \\
\hline Entre grupos & 30830,95 & 10 & 3083,095 & 2,358725 & 0,011626 & 1,876216 \\
Dentro dos grupos & 273184,4 & 209 & 1307,102 & & & \\
Total & 304015,3 & 219 & & & & \\
\hline
\end{tabular}

Tabela 3: resultados do teste estatístico ANOVA para o TM. Houve variação significativa entre os todos informantes: $P<0,05$ e $F_{0}(2,35)>F_{c}(1,87)$ 
Na tabela 3, SQ é a soma dos quadrados, enquanto MQ é a média quadrática do conjunto das colunas, e a razão $\mathrm{F}$ indica a diferença entre os grupos em função da variação dentro de cada grupo. E nela é verificado que há variação significativa entre os informantes, incluindo os do controle, com o valor $\mathrm{P}-0,01(\mathrm{P}<0,05)$.

Considerando apenas as cidades do Médio Tietê, gera-se o próximo cálculo em que, novamente, obtém-se o valor $\mathrm{P}-0,01(\mathrm{P}<0,05)$ :

\begin{tabular}{lcrrcrc}
\hline Fonte da variação & \multicolumn{1}{c}{$S Q$} & gl & \multicolumn{1}{c}{ MQ } & \multicolumn{1}{c}{ F } & valor-P & F crítico \\
\hline Entre grupos & 19687,14 & 6 & 3281,19 & 2,921468 & 0,01041 & 2,167423 \\
Dentro dos grupos & 149376,4 & 133 & 1123,131 & & & \\
Total & 169063,5 & 139 & & & & \\
\hline
\end{tabular}

Tabela 4: resultados do teste estatístico ANOVA para o TM. Houve variação significativa entre os informantes do Médio Tietê: $P<0,05$ e $F_{0}(2,92)>F_{c}(2,16)$

E o mesmo ocorre quando são comparadas as cidades do Médio Tietê com as de Portugal, estabelecendo uma variação significativa ainda maior: $\mathrm{P}-0,003(\mathrm{P}<0,05)$ :

\begin{tabular}{|c|c|c|c|c|c|c|}
\hline Fonte da variação & $S Q$ & $g l$ & $M Q$ & $F$ & valor- $P$ & F crítico \\
\hline Entre grupos & 28822,58 & 9 & 3202,509 & 2,889783 & 0,00318 & 1,929425 \\
\hline Dentro dos grupos & 210561,4 & 190 & 1108,218 & & & \\
\hline Total & 239384 & 199 & & & & \\
\hline
\end{tabular}

Tabela 5: resultados do teste estatístico ANOVA para o TM. Houve variação significativa entre os informantes do Médio Tietê e Portugal: $P<0,05$ e $F_{0}(2,88)>F_{c}(1,92)$

Com os cálculos, percebe-se que há uma diferença, mas ela não é acentuada com a presença do controle. Logo, entende-se que o TM realizado nas cidades do Médio Tietê difere por outras questões que não necessariamente a localidade em que ele ocorre. Por isso, analisaram-se as variações por gêneros e região.

Obtendo a média das cidades do Médio Tietê e as contrapondo entre homens e mulheres da mesma região, teremos os resultados a seguir. As tabelas 6, 7 e 8 destinamse aos falantes masculinos:

\begin{tabular}{l|r|r|r|r|r|r|r|r|r|r|r}
\hline TM cPs & \multicolumn{1}{c|}{ CAP } & \multicolumn{1}{|l|}{ ITU } & \multicolumn{1}{l|}{ PC } & \multicolumn{1}{l|}{ PP } & \multicolumn{1}{c|}{ PF } & SANT & \multicolumn{1}{c|}{ TIE } & BRAGA & BGÇ & \multicolumn{1}{c|}{ VR } & CONTR \\
\hline H1/FR1 & 118 & 173 & 181 & 113 & 179 & 178 & 158 & 133 & 155 & 146 & 142 \\
\hline H1/FR2 & 134 & 153 & 179 & 133 & 170 & 170 & 194 & 156 & 179 & 145 & 121 \\
\hline H1/FR3 & 133 & 172 & 178 & 116 & 169 & 163 & 171 & 143 & 143 & 128 & 157 \\
\hline H1/FR4 & 158 & 176 & 176 & 133 & 141 & 164 & 133 & 167 & 185 & 148 & 109 \\
\hline H1/FR5 & 145 & 173 & 180 & 128 & 202 & 171 & 159 & 172 & 152 & 148 & 170 \\
\hline H2/FR1 & 146 & 160 & 173 & 129 & 150 & 110 & 143 & 175 & 156 & 171 & 144 \\
\hline H2/FR2 & 137 & 169 & 175 & 132 & 169 & 113 & 177 & 193 & 169 & 181 & 132 \\
\hline H2/FR3 & 145 & 156 & 176 & 139 & 152 & 114 & 151 & 192 & 174 & 184 & 140 \\
\hline H2/FR4 & 141 & 170 & 179 & 132 & 156 & 118 & 200 & 166 & 140 & 177 & 132 \\
\hline H2/FR5 & 133 & 170 & 181 & 130 & 154 & 126 & 161 & 266 & 151 & 162 & 130 \\
\hline
\end{tabular}

Tabela 6: comparação do Tom Médio (TM) em unidade cps medido em Hertz somente entre homens das cidades do Médio Tietê, Portugal e controle 
O primeiro exame demonstra que não há variação significativa entre os homens da região do Médio Tietê, com o valor P-5,41 (P>0,05).

\begin{tabular}{lrrrrrl}
\hline Fonte da variação & \multicolumn{1}{c}{$S Q$} & \multicolumn{1}{c}{ SQ } & \multicolumn{1}{c}{ MQ } & \multicolumn{1}{c}{$F$} & valor- $P$ & F crítico \\
\hline Entre grupos & 22148,35 & 7 & 3164,05 & 11,92756 & $5,41 \mathrm{E}-10$ & 2,139656 \\
Dentro dos grupos & 19099,6 & 72 & 265,2722 & & & \\
Total & 41247,95 & 79 & & & & \\
\hline
\end{tabular}

Tabela 7: resultados do teste estatístico ANOVA para o TM. Houve variação não significativa entre os informantes do Médio Tietê: $P>0,05$ e $F_{0}(11,92)>F_{c}(2,13)$

Quando os valores são comparados com as da cidade de Portugal, a variação diminui, mas continua não havendo variação significativa entre os dados, sendo P-1,80 $(\mathrm{P}>0,05)$ :

\begin{tabular}{lcccccc}
\hline Fonte da variação & $S Q$ & gl & $M Q$ & $F$ & valor-P & Fcrítico \\
\hline Entre grupos & 27409 & 10 & 2740,9 & 7,4199 & $1 \mathrm{E}-08$ & 1,9277 \\
Dentro dos grupos & 36570 & 99 & 369,39 & & & \\
Total & 63979 & 109 & & & & \\
\hline
\end{tabular}

Tabela 8: resultados do teste estatístico ANOVA para o TM. Houve variação não significativa entre os informantes do Médio Tietê e Portugal: $P>0,05$ e $F_{0}(7,41)>F_{c}(1,92)$

Seguindo o mesmo princípio de exame, as tabelas 9,10 e 11 são referentes às mulheres:

\begin{tabular}{|c|c|c|c|c|c|c|c|c|c|c|c|}
\hline TM cps & CAP & ITU & PC & PP & PF & SANT & TIE & BRAGA & BGÇ & VR & CONTR \\
\hline M1/FR1 & 179 & 132 & 157 & 219 & 187 & 187 & 185 & 255 & 188 & 189 & 224 \\
\hline M1/FR2 & 130 & 237 & 199 & 217 & 182 & 195 & 204 & 228 & 194 & 188 & 257 \\
\hline M1/FR3 & 156 & 235 & 206 & 235 & 194 & 236 & 202 & 220 & 196 & 243 & 258 \\
\hline M1/FR4 & 182 & 235 & 203 & 218 & 180 & 131 & 202 & 210 & 213 & 215 & 247 \\
\hline M1/FR5 & 156 & 229 & 204 & 184 & 182 & 203 & 180 & 208 & 192 & 199 & 231 \\
\hline M2/FR1 & 196 & 219 & 170 & 165 & 238 & 223 & 209 & 200 & 208 & 196 & 250 \\
\hline M2/FR2 & 168 & 204 & 159 & 15 & 246 & 211 & 255 & 205 & 209 & 224 & 273 \\
\hline M2/FR3 & 180 & 181 & 149 & 185 & 211 & 283 & 266 & 210 & 219 & 232 & 249 \\
\hline M2/FR4 & 197 & 163 & 177 & 188 & 226 & 227 & 241 & 210 & 252 & 217 & 248 \\
\hline M2/FR5 & 189 & 190 & 155 & 162 & 220 & 231 & 241 & 215 & 210 & 209 & 196 \\
\hline
\end{tabular}

Tabela 9: comparação do Tom Médio (TM) em unidade cps medido em Hertz somente entre mulheres das cidades do Médio Tietê, Portugal e controle

Diferentemente dos homens, as mulheres do Médio Tietê apresentaram variação significativa, trazendo o valor de $\mathrm{P}-0,000009(\mathrm{P}<0,05)$.

\begin{tabular}{lrrrrrr}
\hline Fonte da variação & \multicolumn{1}{c}{ SQ } & gl & \multicolumn{1}{c}{ MQ } & \multicolumn{1}{c}{$F$} & valor-P & F crítico \\
\hline Entre grupos & 35798,49 & 7 & 5114,07 & 6,282266 & $9,18 \mathrm{E}-06$ & 2,139656 \\
Dentro dos grupos & 58611,5 & 72 & 814,0486 & & & \\
Total & 94409,99 & 79 & & & & \\
\hline
\end{tabular}

Tabela 10: resultados do teste estatístico ANOVA para o TM. Houve variação significativa entre as informantes do Médio Tietê: $P<0,05$ e $F_{0}(6,28)>F_{c}(2,13)$ 
Todavia, quando são acrescidos os valores das entrevistadas de Portugal, não há variação significativa, sendo $\mathrm{P}-1,53(\mathrm{P}>0,05)$.

\begin{tabular}{|c|c|c|c|c|c|c|}
\hline Fonte da variação & $S Q$ & $g l$ & $M Q$ & $F$ & valor- $P$ & F crítico \\
\hline Entre grupos & 37631 & 10 & 3763,1 & 5,5607 & $2 \mathrm{E}-06$ & 1,9277 \\
\hline Dentro dos grupos & 66997 & 99 & 676,74 & & & \\
\hline Total & 104628 & 109 & & & & \\
\hline
\end{tabular}

Tabela 11: resultados do teste estatístico ANOVA para o TM. Houve variação não significativa entre as informantes do Médio Tietê e Portugal: $P>0,05$ e $F_{0}(5,56)>F_{c}(1,92)$

Individualizando os dados dos falantes masculinos e femininos, nota-se que não houve diferença significativa para os homens, mas existiu para as mulheres do Médio Tietê.

Para compreendermos o que ocorreu, foi acrescido o teste de Dunnett: neste teste, quando há um controle, as comparações de interesse preliminar podem ser usadas para cada novo tratamento com ele. Assim, tendo as tabelas 6 e 9 como parâmetros, comparou-se cada cidade com o controle, e obtiveram-se os dados que seguem nas tabelas 12 e 13. Na primeira coluna, estão discriminadas as cidades do Médio Tietê e Portugal; na segunda, temos o valor F; na terceira, traz se houve variação significante; e a quarta traz o valor-P. A quantidade de asteriscos na coluna "significância" mostra o quão intenso é o grau de significância entre os valores comparados: três asteriscos denotam maior intensidade, enquanto um é menor.

\begin{tabular}{l|c|c|c}
\hline \multicolumn{4}{c}{ Dunnett - TM homens } \\
\hline \multicolumn{1}{c}{ Cidade } & F & Significância & Valor-P \\
\hline CAPIVARI & $-0,75678$ & N.S. $(P>0.05)$ & 0,987382 \\
\hline ITU & $-3,25785$ & $* *(P<=0.01)$ & 0,009627 \\
\hline PIRACICABA & $-3,78534$ & $* *(P<=0.01)$ & 0,001418 \\
\hline PIRAPORA & 1,40482 & N.S. $(P>0.05)$ & 0,671472 \\
\hline PORTO FELIZ & $-2,68658$ & N.S. $(P>0.05)$ & 0,054211 \\
\hline SANTANA & $-0,26477$ & N.S. $(P>0.05)$ & 0,999999 \\
\hline TIETE & $-2,79799$ & $*(P<=0.05)$ & 0,039826 \\
\hline BRAGA & $-2,87361$ & $*(P<=0.05)$ & 0,032049 \\
\hline BRAGANÇA & $-2,53427$ & N.S. $(P>0.05)$ & 0,080784 \\
\hline VILA REAL & $-2,49644$ & N.S. $(P>0.05)$ & 0,088835 \\
\hline
\end{tabular}

Tabela 12: comparação do Tom Médio (TM) entre homens das cidades do Médio Tietê e Portugal. Os dados foram gerados a partir do controle da tabela 6 
De acordo com o teste, as cidades de Capivari, Pirapora do Bom Jesus, Porto Feliz, Santana do Parnaíba, Bragança e Vila Real não possuem variações significativas em relação ao controle, enquanto as demais, sim; o que indica que há coincidências entre o TM utilizado pelos homens em cidades do Médio Tietê, Braga e a fala neutra, não havendo, portanto, uma ordem quando se fala apenas de localidade.

Quanto às mulheres, por meio do mesmo teste também observamos que não há uma tendência de similaridade absolutamente igual entre elas e os homens da mesma região. No caso, apenas Santana de Parnaíba, Tietê e Braga mantêm a regularidade de não terem variação significativa em referência ao controle. Por outro lado, Capivari, Itu, Piracicaba, Pirapora do Bom Jesus, Porto Feliz, Bragança e Vila Real não apresentam variações significativas.

\begin{tabular}{l|c|r|c}
\hline \multicolumn{1}{c|}{ Cidade } & F & Significância & Valor-P \\
\hline CAPIVARI & 3,6690151 & $* *(P<=0.01)$ & 0,00222 \\
\hline ITU & 2,7979892 & $*(P<=0.05)$ & 0,039826 \\
\hline PIRACICABA & 3,4772732 & $* *(P<=0.01)$ & 0,004503 \\
\hline PIRAPORA & 3,3260874 & $* *(P<=0.01)$ & 0,007644 \\
\hline PORTO FELIZ & 3,0248532 & $*(P<=0.05)$ & 0,020359 \\
\hline SANTANA & 2,2308292 & N.S. $(P>0.05)$ & 0,165377 \\
\cline { 2 - 5 } TIETE & 1,8155951 & N.S. $(P>0.05)$ & 0,371766 \\
\hline BRAGA & 2,4983252 & N.S. $(P>0.05)$ & 0,088419 \\
\hline BRAGANÇA & 2,8357998 & $*(P<=0.05)$ & 0,035755 \\
\hline VILA REAL & 2,8746922 & $*(P<=0.05)$ & 0,031948 \\
\hline
\end{tabular}

Tabela 13: comparação do Tom Médio (TM) entre mulheres das cidades do Médio Tietê e Portugal. Os dados foram gerados a partir do controle da tabela 9

Ou seja, em relação aos graus de significância (marcados pelos asteriscos) em ambas as tabelas, repetem-se apenas Itu e Piracicaba, e o restante não coincide. Por isso, observa-se que não há uma simetria tonal comparando os grupos das cidades.

Após a distinção de valores das tabelas mencionadas anteriormente, entende-se que a heterogeneidade dos cálculos presentes nas tabelas 7, 8 e 11 desaparece quando temos a junção dos dados (tabelas 3, 4 e 5). Isto é, o motivo da diferença tem a ver com o sexo de seus informantes, porque os valores que não são similares entre homens e mulheres acabam interferindo na geração de resultados: as frequências fundamentais das vozes masculinas podem variar de 80 a $150 \mathrm{~Hz}$, e as femininas de 150 a $250 \mathrm{~Hz}$ (NEPOMUCENO, 1968; FOLMER-JOHNSON, 1968).

Porém, mesmo havendo essa diferença, ela não se acentua tanto quando os gêneros são contrapostos dentro de uma mesma região. Ao se calcular as médias do Médio Tietê, por meio do teste $\mathrm{F}$, percebe-se que também não teremos diferenças significativas: 


\begin{tabular}{r|r}
\hline Mtietê $\mathbf{h}$ & Mtietê $\mathbf{~}$ \\
\hline 157 & 178 \\
\hline 162 & 195 \\
\hline 157 & 209 \\
\hline 154 & 193 \\
\hline 165 & 191 \\
\hline 144 & 203 \\
\hline 153 & 200 \\
\hline 148 & 208 \\
\hline 157 & 203 \\
\hline 151 & 198 \\
\hline
\end{tabular}

Tabela 14: comparação do Tom Médio (TM) em unidade cps medido em Hertz entre homens e mulheres das cidades do Médio Tietê

Teste-F: duas amostras para variâncias

\begin{tabular}{lrr}
\hline & Mtietê $h$ & Mtietê $m$ \\
\hline Média & 154,8714 & 197,2714 \\
Variância & 39,739 & 85,92494 \\
Observações & 10 & 10 \\
gl & 9 & 9 \\
F & 0,462485 & \\
P(F<=f) uni-caudal & 0,133072 & \\
F crítico uni-caudal & 0,314575 & \\
\hline
\end{tabular}

Tabela 15: resultados do teste estatístico F para o TM. Houve variação não significativa entre os informantes do Médio Tietê: $P>0,05$ e $F_{0}(0,46)>F_{c}(0,31)$

Na primeira comparação, os valores entre homens e mulheres trazem variações não significativas, sendo P-0,13 ( $\mathrm{P}>0,05)$. Todavia, contrapondo-se os falantes de Portugal, nota-se diferença:

\begin{tabular}{r|r}
\hline PORT $\mathbf{h}$ & PORT $\mathbf{~}$ \\
\hline 145 & 211 \\
\hline 160 & 203 \\
\hline 138 & 220 \\
\hline 167 & 213 \\
\hline 157 & 200 \\
\hline 167 & 201 \\
\hline 181 & 213 \\
\hline 183 & 220 \\
\hline 161 & 226 \\
\hline 193 & 211 \\
\hline
\end{tabular}

Tabela 16: comparação do Tom Médio (TM) em unidade cps medido em Hertz entre homens e mulheres das cidades de Portugal 
Teste-F: duas amostras para variâncias

\begin{tabular}{lrr}
\hline & PORTh & PORT $m$ \\
\hline Média & 165,2333 & 211,8 \\
Variância & 291,779 & 75,2642 \\
Observações & 10 & 10 \\
gl & 9 & 9 \\
F & 3,876731 & \\
P(F<=f) uni-caudal & 0,028053 & \\
F crítico uni-caudal & 3,178893 & \\
\hline
\end{tabular}

Tabela 17: resultados do teste estatístico F para o TM. Houve variação significativa entre os informantes de Portugal: $P<0,05$ e $F_{0}(3,87)>F_{c}(3,17)$

A tabela 17 demonstra que houve variação significativa entre os entrevistados de Braga, Bragança e Vila Real, trazendo o P-0,02 ( $<<0,05)$. Mas o mesmo não ocorreu com o controle, conforme vemos nas próximas tabelas 18 e 19.

\begin{tabular}{r|r}
\hline CONTR $\boldsymbol{h}$ & CONTR $\mathbf{~}$ \\
\hline 142 & 224 \\
\hline 121 & 257 \\
\hline 157 & 258 \\
\hline 109 & 247 \\
\hline 170 & 231 \\
\hline 144 & 250 \\
\hline 132 & 273 \\
\hline 140 & 249 \\
\hline 132 & 248 \\
\hline 130 & 196 \\
\hline
\end{tabular}

Tabela 18: comparação do Tom Médio (TM) em unidade cps medido em Hertz entre homens e mulheres do controle

Teste-F: duas amostras para variâncias

\begin{tabular}{lrr}
\hline & CONTR $h$ & CONTR $m$ \\
\hline Média & 137,7 & 243,3 \\
Variância & 300,6778 & 462,2333 \\
Observações & 10 & 10 \\
Gl & 9 & 9 \\
F & 0,650489 & \\
P(F<=f) uni-caudal & 0,265957 & \\
F crítico uni-caudal & 0,314575 & \\
\hline
\end{tabular}

Tabela 19: resultados do teste estatístico $F$ para o TM. Houve variação não significativa entre os informantes do controle: $P>0,05$ e $F_{0}(0,65)>F_{c}(0,31)$

Para o controle, não houve variação significativa, calculando-se um valor P-0,26 $(\mathrm{P}>0,05)$. Todavia, esse é um resultado esperado, pois devemos considerar que o 
controle é justamente a fala neutra em busca de uma padronização. Logo, mesmo havendo a diferença natural de frequência de vozes masculinas e femininas, ambos mantêm-se dentro de um quadro regular.

Entretanto, pensando nessa regularidade no teste-F, os informantes do Médio Tietê também o trouxeram, ao contrário de Portugal, por isso, para verificar essa variação, as falas masculinas e femininas foram comparadas entre as regiões, gerandose os resultados vistos a seguir.

Embora as tabelas 20 e 24 estejam organizadas com três colunas emparelhadas, os cálculos que seguem em 21, 22, 23, 25, 26 e 27 trabalham com duas amostras de variância.

\begin{tabular}{r|r|r}
\hline Mtietê $\mathbf{~}$ & PORT $\mathbf{~}$ & CONTR $\mathbf{~}$ \\
\hline 157 & 145 & 142 \\
\hline 162 & 160 & 121 \\
\hline 157 & 138 & 157 \\
\hline 154 & 167 & 109 \\
\hline 165 & 157 & 170 \\
\hline 144 & 167 & 144 \\
\hline 153 & 181 & 132 \\
\hline 148 & 183 & 140 \\
\hline 157 & 161 & 132 \\
\hline 151 & 193 & 130 \\
\hline
\end{tabular}

Tabela 20: comparação do Tom Médio (TM) em unidade cps medido em Hertz entre homens do Médio Tietê, Portugal e o controle

Teste-F: duas amostras para variâncias

\begin{tabular}{lrr}
\hline & Mtietê $h$ & \multicolumn{1}{c}{ CONTR } \\
\hline Média & 154,8714 & 137,7 \\
Variância & 39,739 & 300,6778 \\
Observações & 10 & 10 \\
Gl & 9 & 9 \\
F & 0,132165 & \\
P(F<=f) uni-caudal & 0,002962 & \\
F crítico uni-caudal & 0,314575 & \\
\hline
\end{tabular}

Tabela 21: resultados do teste estatístico F para o TM. Houve variação significativa entre os informantes do Médio Tietê e controle: $P<0,05$ e $F_{0}(0,13)<F_{c}(0,31)$

Iniciando a comparação entre os falantes masculinos do Médio Tietê e o controle, notamos que há variação significativa entre as médias, com resultado P-0,002 $(\mathrm{P}<0,05)$. 


\begin{tabular}{lrr}
\multicolumn{3}{l}{ Teste-F: duas amostras para variâncias } \\
\hline Média & \multicolumn{1}{c}{ PORTh } & \multicolumn{1}{c}{ CONTR } \\
\hline Variância & 165,2333 & 137,7 \\
Observações & 291,779 & 300,6778 \\
gl & 10 & 10 \\
F & 9 & 9 \\
P(F<=f) uni-caudal & 0,970404 & \\
F crítico uni-caudal & 0,48252 & \\
\hline
\end{tabular}

Tabela 22: resultados do teste estatístico F para o TM. Houve variação não significativa entre os informantes de Portugal e controle: $P>0,05$ e $F_{0}(0,97)>F_{c}(0,31)$

Entretanto, entre os informantes portugueses e o controle, a variação não é significativa, com valor de $\mathrm{P}-0,48(\mathrm{P}>0,05)$.

\begin{tabular}{lrr}
\multicolumn{3}{l}{ Teste-F: duas amostras para variâncias } \\
\hline & Mtietê $h$ & \multicolumn{1}{c}{ PORT $h$} \\
\hline Média & 154,8714 & 165,2333 \\
Variância & 39,739 & 291,779 \\
Observações & 10 & 10 \\
gl & 9 & 9 \\
F & 0,136196 & \\
P(F<=f) uni-caudal & 0,003304 & \\
F crítico uni-caudal & 0,314575 & \\
\hline
\end{tabular}

Tabela 23: resultados do teste estatístico F para o TM. Houve variação significativa entre os informantes de Portugal e Médio Tietê: $P<0,05$ e $F_{0}(0,13)<F_{c}(0,31)$

Em relação à comparação entre os portugueses e os informantes do Médio Tietê, tem-se uma variação significativa, com $\mathrm{P}-0,003(\mathrm{P}<0,05)$.

Agindo da mesma forma com os dados femininos, vejamos os resultados:

\begin{tabular}{r|r|r}
\hline Mtietê $\mathbf{m}$ & PORT $\mathbf{m}$ & CONTR $\mathbf{~}$ \\
\hline 178 & 211 & 224 \\
\hline 195 & 203 & 257 \\
\hline 209 & 220 & 258 \\
\hline 193 & 213 & 247 \\
\hline 191 & 200 & 231 \\
\hline 203 & 201 & 250 \\
\hline 200 & 213 & 273 \\
\hline 208 & 220 & 249 \\
\hline 203 & 226 & 248 \\
\hline 198 & 211 & 196 \\
\hline
\end{tabular}

Tabela 24: comparação do Tom Médio (TM) em unidade cps medido em Hertz entre mulheres do Médio Tietê, Portugal e o controle 
Teste-F: duas amostras para variâncias

\begin{tabular}{lrr}
\hline & Mtietê $m$ & CONTR \\
\hline Média & 197,8 & 243,3 \\
Variância & 83,70159 & 462,2333 \\
Observações & 10 & 10 \\
$\mathrm{gl}$ & 9 & 9 \\
$\mathrm{~F}$ & 0,181081 & \\
$\mathrm{P}(\mathrm{F}<=\mathrm{f})$ uni-caudal & 0,008991 & \\
F crítico uni-caudal & 0,314575 & \\
\hline
\end{tabular}

Tabela 25: resultados do teste estatístico F para o TM. Houve variação significativa entre as informantes do Médio Tietê e controle: $P<0,05$ e $F_{0}(0,18)<F_{c}(0,31)$

Entre as amostras do Médio Tietê e controle, houve variação significativa, gerando-se um valor $\mathrm{P}-0,008(\mathrm{P}<0,05)$.

Teste-F: duas amostras para variâncias

\begin{tabular}{lrr}
\hline & PORT $m$ & \multicolumn{1}{c}{ CONTR } \\
\hline Média & 211,8 & 243,3 \\
Variância & 75,2642 & 462,2333 \\
Observações & 10 & 10 \\
gl & 9 & 9 \\
F & 0,162827 & \\
P(F<=f) uni-caudal & 0,006239 & \\
F crítico uni-caudal & 0,314575 & \\
\hline
\end{tabular}

Tabela 26: resultados do teste estatístico F para o TM. Houve variação significativa entre as informantes de Portugal e controle: $P<0,05$ e $F_{0}(0,16)<F_{c}(0,31)$

O mesmo ocorre entre os informantes de Portugal e o controle, havendo variação significativa, sendo $\mathrm{P}-0,006(\mathrm{P}<0,05)$.

Teste-F: duas amostras para variâncias

\begin{tabular}{lll}
\hline & Mtietê $m$ & PORT $m$ \\
\hline Média & 197,8 & 211,8 \\
Variância & 83,70159 & 75,2642 \\
Observações & 10 & 10 \\
$\mathrm{gl}$ & 9 & 9 \\
$\mathrm{~F}$ & 1,112104 \\
$\mathrm{P}(\mathrm{F}<=\mathrm{f})$ uni-caudal & 0,438416 \\
F crítico uni-caudal & 3,178893 \\
\hline
\end{tabular}

Tabela 27: resultados do teste estatístico F para o TM. Houve variação não significativa entre as informantes do Médio Tietê e Portugal: $P>0,05$ e $F_{0}(1,11)<F_{c}(3,17)$ 
No entanto, comparando as duas amostras das informantes do Médio Tietê e de Portugal, não há variação significativa, tendo o valor $\mathrm{P}-0,43(\mathrm{P}>0,05)$.

De modo geral, contrapondo os resultados do teste-F entre homens e mulheres do Médio Tietê, vemos nas tabelas 21 e 25 que há variação significativa em relação ao controle. Porém, tratando-se de Portugal, os valores diferem, já que a tabela 23 (público masculino) traz variação significativa, e a 27 (público feminino), não. Outra assimetria aparece quando retomamos o teste ANOVA com os valores individualizados: as tabelas 7 e 8 mostram que não há diferença entre os informantes masculinos do Médio Tietê e de Portugal; enquanto a 10 e 11, relacionadas às mulheres, demonstraram variação significativa entre o público do interior paulista, e não significativa comparando com as portuguesas, respectivamente. Assim, em dois testes, as mulheres do Médio Tietê e Portugal não apresentam variações, mas os dos homens trazem resultados distintos.

Buscando os valores brutos do teste de Dunnett (tabelas 12 e 13), demonstra-se que não há uma homogeneidade de dados.

Tal fato é visto quando os valores são tratados no teste ANOVA destacando o Médio Tietê, ou comparando-o com o controle, ou com Portugal (tabelas 3, 4 e 5): todos os resultados trouxeram variações significativas, com o valor-P inferior a 0,05 , sendo P0,01 em 3 e 4, e P-0,003 em 5.

Desta forma, podemos concluir que as análises estatísticas nos mostram que os valores não são absolutos nem fechados em uma característica comum, reclusa a uma região ou a um gênero. Logo, levando tais resultados para os estudos sociolinguísticos, vemos que a teoria espacial ou neolinguística de Matteo Bartoli (1945) não se aplica, pois o isolamento das cidades ou suas colonizações semelhantes não garantiram uma variação dialetal tão distinta de modo a considerá-la uma caracterização. Como exemplo, observemos que a diferença de médias entre as colunas de Tietê (TIE) e o controle (CONTR) é de apenas $0,4 \%$; enquanto a diferença entre Capivari (CAP), que está somente a $31,5 \mathrm{~km}$ de distância de Tietê, é de $18 \%$. Em se tratando das cidades de Portugal, vemos que a diferença entre Braga e Itu é de apenas 0,3\%, de Porto Feliz (PF) e Vila Real (VR) não passa de 0,1\%, enquanto entre Braga e Bragança (BGÇ) é de $6,1 \%$. Vejamos o gráfico: 


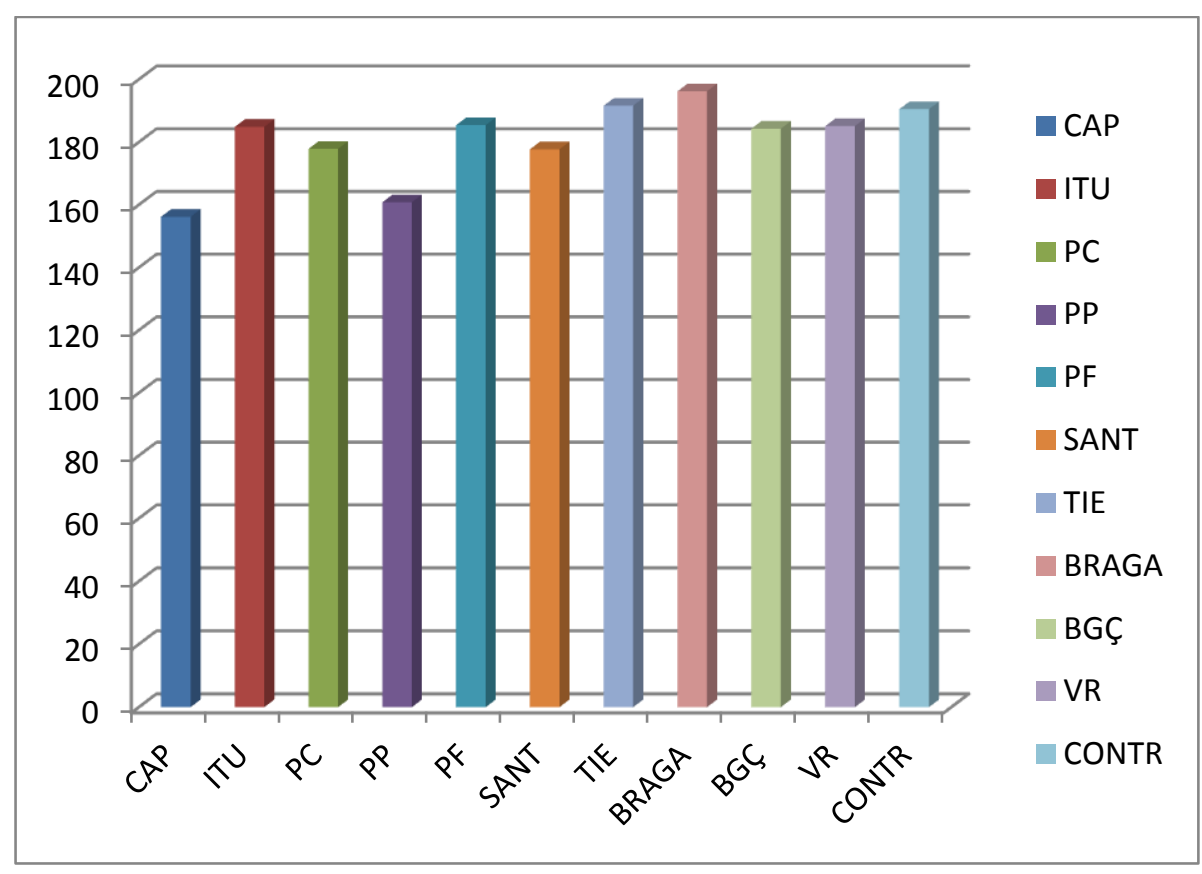

Gráfico 5: comparação do Tom Médio (TM) em unidade cps medido em Hertz (linha vertical) entre as cidades do Médio Tietê, Portugal e o controle (linha horizontal)

Os totens demonstram que não há uma regularidade, estando Itu, Porto Feliz, Tietê, as cidades portuguesas e o controle $\geq 180 \mathrm{cps}$, enquanto Piracicaba e Santana de Parnaíba $\leq 180 \mathrm{cps}$, e somente Capivari e Pirapora do Bom Jesus $<160 \mathrm{cps}$.

Quanto à separação de gêneros, no gráfico 6 observamos que o TM masculino do Médio Tietê e de Portugal é mais agudo do que o controle, enquanto as mulheres são mais graves.

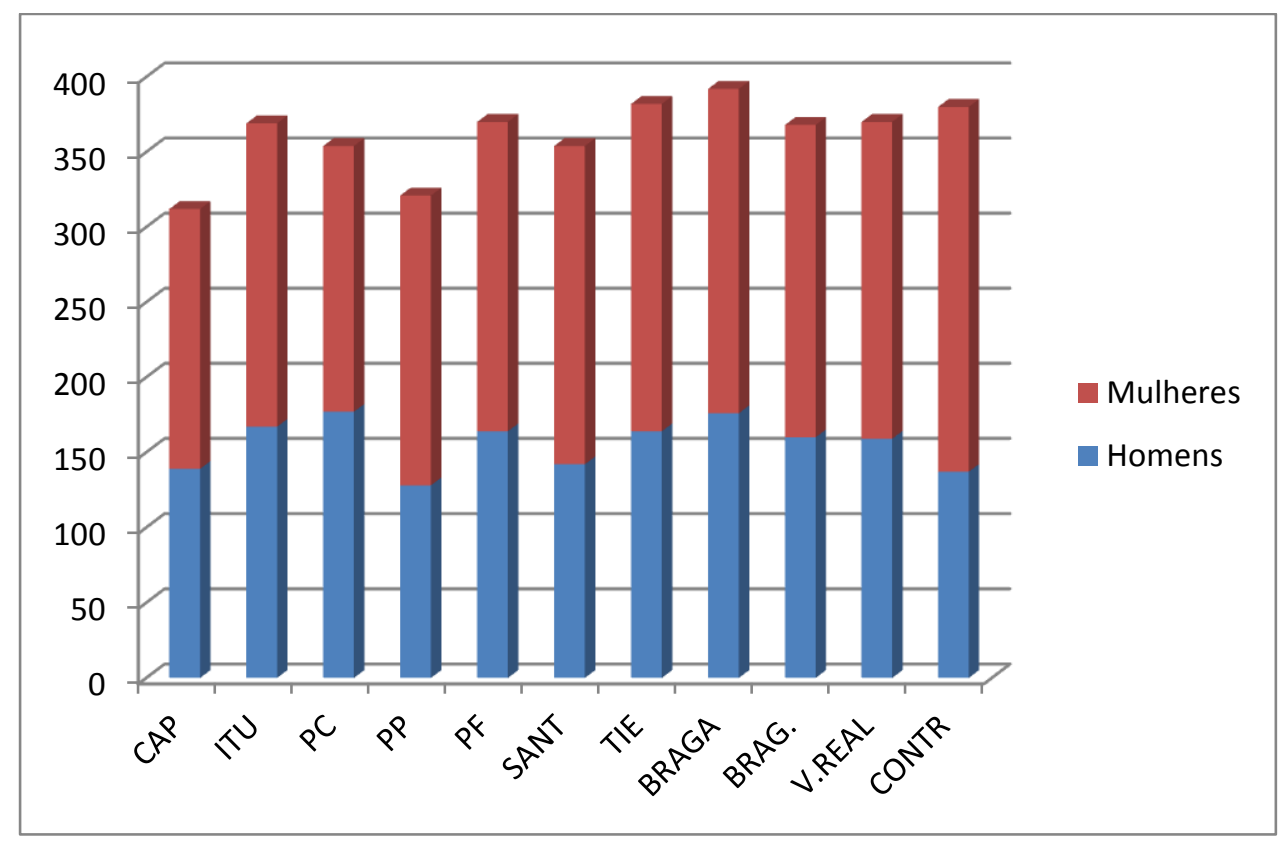

Gráfico 6: comparação de TM entre categorias - mulheres e homens - em unidade cps medido em Hertz (linha vertical) entre as cidades do Médio Tietê, Portugal e o controle (linha horizontal) 


\subsection{O tom final}

O estudo do tom final (TF) seguiu o mesmo caminho do TM, ou seja, após gerados os valores, compararam-se todos os dados dos informantes de forma conjunta; depois, verificou-se o grau de variação significante de acordo com as variantes sexo e região, fazendo-se análises por meio dos testes ANOVA, Dunnett e F. Do mesmo modo, para obterem-se os cálculos do TF dos informantes, utilizou-se o ExProsodia (FERREIRA NETTO, 2008), que tem como base o grau de escala de 5 tons medidos em Hertz, sendo que, para cada banda de sequência, há 3 st (semitons), baseada na frequência média da linha sonora da fala, que forma o centro do tom médio 3.

As tabelas também seguem os mesmos modelos anteriores do item 1.1, assim, iniciamos as análises com os seguintes dados:

\begin{tabular}{l|r|r|r|r|r|r|r|r|r|r|r}
\hline Tom Final & \multicolumn{1}{|c|}{ CAP } & \multicolumn{1}{|c|}{ ITU } & \multicolumn{1}{l|}{ PC } & \multicolumn{1}{l|}{ PP } & \multicolumn{1}{c|}{ PF } & SANT & \multicolumn{1}{l}{ TIE } & BRAGA & BGÇ & VR & CONTR \\
\hline H1/FR1 & 172 & 171 & 128 & 105 & 117 & 196 & 150 & 181 & 225 & 240 & 124 \\
\hline H1/FR2 & 70 & 142 & 245 & 140 & 138 & 225 & 203 & 174 & 220 & 105 & 90 \\
\hline H1/FR3 & 74 & 183 & 238 & 102 & 133 & 154 & 245 & 116 & 104 & 230 & 143 \\
\hline H1/FR4 & 105 & 116 & 166 & 162 & 127 & 200 & 73 & 180 & 188 & 95 & 69 \\
\hline H1/FR5 & 91 & 244 & 156 & 100 & 122 & 140 & 130 & 164 & 129 & 121 & 182 \\
\hline H2/FR1 & 176 & 134 & 158 & 73 & 225 & 82 & 81 & 109 & 202 & 155 & 88 \\
\hline H2/FR2 & 134 & 132 & 107 & 108 & 160 & 82 & 138 & 223 & 251 & 162 & 87 \\
\hline H2/FR3 & 100 & 143 & 153 & 86 & 174 & 89 & 114 & 148 & 142 & 174 & 119 \\
\hline H2/FR4 & 105 & 188 & 144 & 108 & 165 & 92 & 136 & 94 & 159 & 165 & 152 \\
\hline H2/FR5 & 151 & 140 & 128 & 106 & 123 & 96 & 219 & 220 & 172 & 111 & 122 \\
\hline M1/FR1 & 196 & 93 & 204 & 150 & 291 & 135 & 166 & 236 & 177 & 149 & 148 \\
\hline M1/FR2 & 98 & 228 & 184 & 278 & 181 & 186 & 178 & 151 & 159 & 254 & 244 \\
\hline M1/FR3 & 209 & 320 & 191 & 233 & 172 & 186 & 127 & 166 & 190 & 142 & 252 \\
\hline M1/FR4 & 139 & 189 & 178 & 144 & 192 & 136 & 172 & 138 & 191 & 156 & 206 \\
\hline M1/FR5 & 145 & 195 & 180 & 126 & 133 & 188 & 141 & 212 & 182 & 159 & 172 \\
\hline M2/FR1 & 185 & 213 & 148 & 121 & 359 & 235 & 211 & 290 & 326 & 126 & 220 \\
\hline M2/FR2 & 119 & 183 & 133 & 142 & 160 & 158 & 366 & 316 & 157 & 190 & 276 \\
\hline M2/FR3 & 164 & 135 & 186 & 271 & 148 & 234 & 343 & 137 & 205 & 219 & 176 \\
\hline M2/FR4 & 146 & 150 & 174 & 143 & 169 & 240 & 373 & 203 & 314 & 355 & 205 \\
\hline M2/FR5 & 176 & 149 & 180 & 214 & 161 & 199 & 437 & 213 & 163 & 123 & 212 \\
\hline
\end{tabular}

Tabela 28: comparação do Tom Final (TF) medido em Hertz entre as cidades do Médio Tietê, Portugal e o controle SP

\begin{tabular}{lrrrccc}
\hline Fonte da variação & \multicolumn{1}{c}{$S Q$} & \multicolumn{1}{c}{ gl } & MQ & \multicolumn{1}{c}{ v } & valor-P & F crítico \\
\hline Entre grupos & 66972,91 & 10 & 6697,291 & 1,845018 & 0,054708 & 1,876216 \\
Dentro dos grupos & 758656,1 & 209 & 3629,933 & & & \\
Total & 825629 & 219 & & & & \\
\hline
\end{tabular}

Tabela 29: resultados do teste estatístico ANOVA para o TF. Houve variação não significativa entre os informantes de todas as regiões: $P>0,05$ e $F_{0}(1,84)<F_{c}(1,87)$

O primeiro teste Anova fator único em relação ao TF, na tabela 29, demonstra que não há uma diferença significativa entre o tom final de todas as cidades, já que P- 
0,054 ( $\mathrm{P}>0,05)$, embora o resultado seja muito próximo do valor-P pré-determinado como padrão (P-0,05).

Tal resultado repete-se, mas com valor-P superior, com o teste das cidades do Médio Tietê, excetuando o controle e Portugal:

\begin{tabular}{|c|c|c|c|c|c|c|}
\hline Fonte da variação & $S Q$ & $g l$ & $M Q$ & $F$ & valor-P & F crítico \\
\hline Entre grupos & 35331,49 & 6 & 5888,581 & 1,791888 & 0,105384 & 2,167423 \\
\hline Dentro dos grupos & 437070,4 & 133 & 3286,244 & & & \\
\hline Total & 472401,9 & 139 & & & & \\
\hline
\end{tabular}

Tabela 30: resultados do teste estatístico ANOVA para o TF. Houve variação não significativa entre os informantes do Médio Tietê: $P>0,05$ e $F_{0}(1,79)<F_{c}(2,16)$

Ou seja, entre as localidades do Médio Tietê, o teste revela que não há variações significativas, o que nos remete à compreensão de que há cidades do Médio Tietê que corroboram os valores do controle.

Todavia, quando as cidades portuguesas são comparadas, o resultado difere:

\begin{tabular}{|c|c|c|c|c|c|c|}
\hline Fonte da variação & $S Q$ & $g l$ & $M Q$ & $F$ & valor- $P$ & F crítico \\
\hline Entre grupos & 66216,5 & 9 & 7357,389 & 2,025603 & 0,038505 & 1,929425 \\
\hline Dentro dos grupos & 690117,5 & 190 & 3632,197 & & & \\
\hline Total & 756334 & 199 & & & & \\
\hline
\end{tabular}

Tabela 31: resultados do teste estatístico ANOVA para o TF. Houve variação significativa entre os informantes do Médio Tietê e Portugal: $P<0,05$ e $F_{0}(2,02)>F_{c}(1,92)$

De acordo com o teste, o valor-P é $0,03 \quad(\mathrm{P}<0,05)$, logo, temos variação significativa entre as regiões.

Porém, como a diferença de tom feminino para o masculino, em conjunto, pode compensar valores, façamos a análise dos grupos separadamente:

\begin{tabular}{l|r|r|r|r|c|r|r|r|r|r|r}
\hline Tom Final & \multicolumn{1}{c|}{ CAP } & ITU & PC & PP & PF & SANT & TIE & BRAGA & BGÇ & VR & CONTR \\
\hline H1/FR1 & 172 & 171 & 128 & 105 & 117 & 196 & 150 & 181 & 225 & 240 & 124 \\
\hline H1/FR2 & 70 & 142 & 245 & 140 & 138 & 225 & 203 & 174 & 220 & 105 & 90 \\
\hline H1/FR3 & 74 & 183 & 238 & 102 & 133 & 154 & 245 & 116 & 104 & 230 & 143 \\
\hline H1/FR4 & 105 & 116 & 166 & 162 & 127 & 200 & 73 & 180 & 188 & 95 & 69 \\
\hline H1/FR5 & 91 & 244 & 156 & 100 & 122 & 140 & 130 & 164 & 129 & 121 & 182 \\
\hline H2/FR1 & 176 & 134 & 158 & 73 & 225 & 82 & 81 & 109 & 202 & 155 & 88 \\
\hline H2/FR2 & 134 & 132 & 107 & 108 & 160 & 82 & 138 & 223 & 251 & 162 & 87 \\
\hline H2/FR3 & 100 & 143 & 153 & 86 & 174 & 89 & 114 & 148 & 142 & 174 & 119 \\
\hline H2/FR4 & 105 & 188 & 144 & 108 & 165 & 92 & 136 & 94 & 159 & 165 & 152 \\
\hline H2/FR5 & 151 & 140 & 128 & 106 & 123 & 96 & 219 & 220 & 172 & 111 & 122 \\
\hline
\end{tabular}

Tabela 32: comparação do Tom Final (TF) dos homens medido em Hertz nas cidades do Médio Tietê, Portugal e controle 
ANOVA

\begin{tabular}{lrrrrrr}
\hline \multicolumn{1}{c}{ Fonte da variação } & \multicolumn{1}{c}{$S Q$} & \multicolumn{1}{c}{ gl } & MQ & \multicolumn{1}{c}{$F$} & valor-P & F crítico \\
\hline Entre grupos & 49446 & 10 & 4944,6 & 2,604 & 0,0075 & 1,9277 \\
Dentro dos grupos & 187986 & 99 & 1898,8 & & & \\
Total & 237432 & 109 & & & & \\
\hline
\end{tabular}

Tabela 33: resultados do teste estatístico ANOVA para o TF. Houve variação significativa entre os informantes masculinos de todas as localidades: $P<0,05$ e $F_{0}(2,60)>F_{c}(1,92)$

Na tabela 33, também houve variação significativa entre todos os informantes, sendo P-0,007 $(\mathrm{P}<0,05)$.

Analisando as tabelas 34 e 35, teremos resultados diversos:

\begin{tabular}{|c|c|c|c|c|c|c|}
\hline Fonte da variação & $S Q$ & $g l$ & $M Q$ & $F$ & valor-P & F crítico \\
\hline Entre grupos & 24925 & 6 & 4154,2 & 2,2315 & 0,0514 & 2,2464 \\
\hline Dentro dos grupos & 117282 & 63 & 1861,6 & & & \\
\hline Total & 142207 & 69 & & & & \\
\hline
\end{tabular}

Tabela 34: resultados do teste estatístico ANOVA para o TF. Houve variação não significativa entre os informantes masculinos do Médio Tietê: $P>0,05$ e $F_{0}(2,23)<F_{c}(2,24)$

Fazendo-se a comparação apenas entre as cidades do Médio Tietê, percebe-se o valor-P de 0,051 ( $\mathrm{P}>0,05)$. Assim como os resultados da tabela 29, o valor-P ficou muito próximo do padrão determinado como ideal para haver a variação significativa, porém, de forma bastante sutil, isso não aconteceu.

ANOVA

\begin{tabular}{lrrrrrr}
\hline Fonte da variação & \multicolumn{1}{c}{$S Q$} & gl & MQ & \multicolumn{1}{c}{$F$} & valor-P & F crítico \\
\hline Entre grupos & 41199 & 9 & 4577,6 & 2,3274 & 0,0209 & 1,9856 \\
Dentro dos grupos & 177012 & 90 & 1966,8 & & & \\
Total & 218210 & 99 & & & & \\
\hline
\end{tabular}

Tabela 35: resultados do teste estatístico ANOVA para o TF. Houve variação significativa entre os informantes masculinos do Médio Tietê e Portugal: $P<0,05$ e $F_{0}(2,32)>F_{c}(1,98)$

Quando comparados os informantes do Médio Tietê com os de Portugal, há uma variação significativa, gerando-se $\mathrm{P}-0,02 \quad(\mathrm{P}<0,05)$. O mesmo ocorre quando se confrontam os dados com o controle:

\begin{tabular}{|c|c|c|c|c|c|c|}
\hline Fonte da variação & $S Q$ & $g l$ & $M Q$ & $F$ & valor-P & F crítico \\
\hline Entre grupos & 29389 & 7 & 4198,4 & 2,3569 & 0,0317 & 2,1397 \\
\hline Dentro dos grupos & 128256 & 72 & 1781,3 & & & \\
\hline Total & 157644 & 79 & & & & \\
\hline
\end{tabular}

Tabela 36: resultados do teste estatístico ANOVA para o TF. Houve variação significativa entre os informantes masculinos do Médio Tietê e controle: $P<0,05$ e $F_{0}(2,35)>F_{c}(2,13)$ 
De acordo com a tabela 36, há variação significativa entre o Médio Tietê e o controle, sendo P-0,03 $(\mathrm{P}<0,05)$.

Em relação às mulheres, o teste Anova fator único realizado com os dados da tabela 37 diferencia-se do masculino mostrado na 33, demonstrando que não houve diferença significativa entre elas.

\begin{tabular}{l|r|r|r|r|r|r|r|r|r|r|r}
\hline Tom Final & \multicolumn{1}{|c|}{ CAP } & \multicolumn{1}{|c|}{ ITU } & \multicolumn{1}{c|}{ PC } & \multicolumn{1}{l|}{ PP } & \multicolumn{1}{c|}{ PF } & SANT & \multicolumn{1}{c|}{ TIE } & BRAGA & BGÇ & VR & CONTR \\
\hline M1/FR1 & 196 & 93 & 204 & 150 & 291 & 135 & 166 & 236 & 177 & 149 & 148 \\
\hline M1/FR2 & 98 & 228 & 184 & 278 & 181 & 186 & 178 & 151 & 159 & 254 & 244 \\
\hline M1/FR3 & 209 & 320 & 191 & 233 & 172 & 186 & 127 & 166 & 190 & 142 & 252 \\
\hline M1/FR4 & 139 & 189 & 178 & 144 & 192 & 136 & 172 & 138 & 191 & 156 & 206 \\
\hline M1/FR5 & 145 & 195 & 180 & 126 & 133 & 188 & 141 & 212 & 182 & 159 & 172 \\
\hline M2/FR1 & 185 & 213 & 148 & 121 & 359 & 235 & 211 & 290 & 326 & 126 & 220 \\
\hline M2/FR2 & 119 & 183 & 133 & 142 & 160 & 158 & 366 & 316 & 157 & 190 & 276 \\
\hline M2/FR3 & 164 & 135 & 186 & 271 & 148 & 234 & 343 & 137 & 205 & 219 & 176 \\
\hline M2/FR4 & 146 & 150 & 174 & 143 & 169 & 240 & 373 & 203 & 314 & 355 & 205 \\
\hline M2/FR5 & 176 & 149 & 180 & 214 & 161 & 199 & 437 & 213 & 163 & 123 & 212 \\
\hline
\end{tabular}

Tabela 37: comparação do Tom Final (TF) das mulheres medido em Hertz nas cidades do Médio Tietê

\begin{tabular}{lrrrrrr}
\hline \multicolumn{1}{c}{ Fonte da variação } & \multicolumn{1}{c}{$S Q$} & \multicolumn{1}{c}{ gl } & \multicolumn{1}{c}{ MQ } & \multicolumn{1}{c}{$F$} & valor- $P$ & F crítico \\
\hline Entre grupos & 57973 & 10 & 5797,3 & 1,471 & 0,1616 & 1,9277 \\
Dentro dos grupos & 390162 & 99 & 3941 & & & \\
Total & 448135 & 109 & & & & \\
\hline
\end{tabular}

Tabela 38: resultados do teste estatístico ANOVA para o TF. Houve variação não significativa entre todos os informantes femininos: $P>0,05$ e $F_{0}(1,47)<F_{c}(1,92)$

Não houve variação significativa, pois o valor-P é 0,16 (P>0,05), superior ao padrão.

Porém, assim como os resultados masculinos, haverá diferentes resultados ao ser comparado com demais grupos.

\begin{tabular}{lrrrrrr}
\hline \multicolumn{1}{c}{ Fonte da variação } & \multicolumn{1}{c}{ SQ } & gl & MQ & $F$ & valor-P & F crítico \\
\hline Entre grupos & 51283 & 6 & 8547,2 & 2,0635 & 0,0702 & 2,2464 \\
Dentro dos grupos & 260953 & 63 & 4142,1 & & & \\
Total & 312236 & 69 & & & & \\
\hline
\end{tabular}

Tabela 39: resultados do teste estatístico ANOVA para o TF. Houve variação não significativa entre os informantes femininos do Médio Tietê: $P>0,05$ e $F_{0}(2,06)<F_{c}(2,24)$

Entre as informantes das cidades do interior de São Paulo, não houve variação significativa, sendo o valor-P é 0,07 ( $\mathrm{P}>0,05)$, tal qual ocorreu com os entrevistados masculinos, conforme tabela 34. 
ANOVA

\begin{tabular}{lcrrrrr}
\hline Fonte da variação & \multicolumn{1}{c}{$S Q$} & gl & \multicolumn{1}{c}{$M Q$} & \multicolumn{1}{c}{$F$} & valor-P & F crítico \\
\hline Entre grupos & 55278 & 9 & 6142 & 1,4689 & 0,1716 & 1,9856 \\
Dentro dos grupos & 376309 & 90 & 4181,2 & & & \\
Total & 431587 & 99 & & & & \\
\hline
\end{tabular}

Tabela 40: resultados do teste estatístico ANOVA para o TF. Houve variação não significativa entre os informantes femininos do Médio Tietê e Portugal: $P>0,05$ e $F_{0}(1,46)<F_{c}(1,98)$

$\mathrm{Na}$ tabela 40, também não houve variação significativa entre os informantes do Médio Tietê e Portugal, com P-0,17 (P>0,05), ao contrário do resultado da tabela 35 com os dados masculinos.

\begin{tabular}{|c|c|c|c|c|c|c|}
\hline Fonte da variação & $S Q$ & $g l$ & $M Q$ & $F$ & valor-P & F crítico \\
\hline Entre grupos & 54723 & 7 & 7817,6 & 2,0482 & 0,0605 & 2,1397 \\
\hline Dentro dos grupos & 274806 & 72 & 3816,7 & & & \\
\hline Total & 329529 & 79 & & & & \\
\hline
\end{tabular}

Tabela 41: resultados do teste estatístico ANOVA para o TF. Houve variação não significativa entre os informantes femininos do Médio Tietê e o controle: $P>0,05$ e $F_{0}(2,04)<F_{c}(2,13)$

E o mesmo repete-se quando os dados são comparados com o controle: não há variação significativa, gerando $\mathrm{P}-0,06(\mathrm{P}>0,05)$.

Assim, com o teste de comparações múltiplas, os valores masculinos mostraram que existe uma diferença entre os falantes das cidades do interior de São Paulo, não ocorrendo o mesmo quando esses valores são comparados a Portugal e ao controle; enquanto os femininos demonstram que não há diferenças entre o dialeto caipira, o controle ou entre os falares das portuguesas.

Sendo assim, far-se-á o uso do teste de Dunnett para testar as médias com o nível padrão. Primeiramente, serão conferidos os dados masculinos.

\begin{tabular}{l|c|c|r}
\hline \multicolumn{5}{c}{ Dunnett - TF homens } \\
\hline \multicolumn{1}{c}{ Cidade } & F & Significância & \multicolumn{1}{c}{ Valor-P } \\
\hline CAPIVARI & $-0,07562$ & N.S. $(P>0.05)$ & 1 \\
\hline ITU & $-2,15521$ & N.S. $(P>0.05)$ & 0,194515 \\
\hline PIRACICABA & $-2,41988$ & N.S. $(P>0.05)$ & 0,107137 \\
\hline PIRAPORA & 0,604971 & N.S. $(P>0.05)$ & 0,997683 \\
\hline PORTO FELIZ & $-1,7771$ & N.S. $(P>0.05)$ & 0,396669 \\
\hline SANTANA & $-0,68059$ & N.S. $(P>0.05)$ & 0,994199 \\
\hline TIETE & $-1,13389$ & N.S. $(P>0.05)$ & 0,860111 \\
\hline BRAGA & $-1,96542$ & N.S. $(P>0.05)$ & 0,284017 \\
\hline BRAGANÇA & $-2,72134$ & $*(P<=0.05)$ & 0,049312 \\
\hline VILA REAL & $-1,73864$ & N.S. $(P>0.05)$ & 0,422449 \\
\hline
\end{tabular}

Tabela 42: comparação do Tom Final (TF) entre homens das cidades do Médio Tietê e Portugal. Os dados foram gerados a partir do controle da tabela 32 
Com esse teste, percebemos que, mesmo as tabelas 33, 35 e 36 apresentando a presença significativa de variação, não a há entre o dialeto caipira de cada cidade e a fala neutra. No caso das cidades portuguesas, a única que apresentou diferença dos demais resultados foi Bragança, com um valor de baixa significância.

Em relação aos dados femininos, porém, o teste de Dunnett e os ANOVA foram coincidentes, porque não apresentaram variações significativas:

\begin{tabular}{l|r|l|r}
\hline \multicolumn{5}{c}{ Dunnett - TF mulheres } \\
\hline \multicolumn{1}{c|}{ Cidade } & F & Significância & \multicolumn{1}{c}{ Valor-P } \\
\hline CAPIVARI & 2,6845572 & N.S. $(P>0.05)$ & 0,054508 \\
\hline ITU & 1,2094863 & N.S. $(P>0.05)$ & 0,813199 \\
\hline PIRACICABA & 2,0047196 & N.S. $(P>0.05)$ & 0,263498 \\
\hline PIRAPORA & 1,2850792 & N.S. $(P>0.05)$ & 0,76101 \\
\hline PORTO FELIZ & 1,4373461 & N.S. $(P>0.05)$ & 0,646405 \\
\hline SANTANA & 1,2099413 & N.S. $(P>0.05)$ & 0,812899 \\
\hline TIETE & $-0,0378107$ & N.S. $(P>0.05)$ & 1 \\
\hline BRAGA & 0,4915386 & N.S. $(P>0.05)$ & 0,99959 \\
\hline BRAGANÇA & 0,8696453 & N.S. $(P>0.05)$ & 0,967875 \\
\hline VILA REAL & 1,436265 & N.S. $(P>0.05)$ & 0,64724 \\
\hline
\end{tabular}

Tabela 43: comparação do Tom Final (TF) entre as mulheres das cidades do Médio Tietê. Os dados foram gerados a partir do controle SP da tabela 37

Para as tabelas 42 e 43, chama-se a atenção a similaridade do valor-P entre as cidades. Nos dados masculinos, embora se difiram entre si, Capivari, Santana de Parnaíba e Pirapora do Bom Jesus possuem um grau de significância alto em relação ao padrão $(\mathrm{P}<0,05)$, com resultados por volta de $\mathrm{P}-1$. E Porto Feliz e Vila Real se assemelham também, com o valor-P aproximado a P-0,4.

Considerando o teste de Dunnett feminino, Itu e Santana de Parnaíba trazem resultados quase idênticos (P-0,81), enquanto Tietê, Braga e Bragança apresentam o valor-P em torno de 1 . Sendo assim, pensando em questões de circunvizinhança, o teste demonstra que considerar individualmente os locais não é um fator relevante para determinar semelhanças linguísticas regionais, já que cidades de Portugal assemelhamse com as do Médio Tietê, enquanto localidades com pouca quilometragem de distância não coincidem, como Capivari e Porto Feliz (30,3 km), ou Piracicaba e Tietê (46,1 km).

Em se tratando do teste-F, as médias do TF também foram analisadas. Primeiramente, verificou-se a diferença entre as mesmas regiões, e não houve variação significativa. 


\begin{tabular}{r|r}
\hline Mtietê $\mathbf{h}$ & Mtietê $\mathbf{~}$ \\
\hline 148 & 176 \\
\hline 166 & 190 \\
\hline 161 & 205 \\
\hline 136 & 164 \\
\hline 140 & 158 \\
\hline 133 & 210 \\
\hline 123 & 180 \\
\hline 123 & 212 \\
\hline 134 & 199 \\
\hline 138 & 181 \\
\hline
\end{tabular}

Tabela 44: comparação do Tom Final (TF) entre mulheres e homens do Médio Tietê

Teste-F: duas amostras para variâncias

\begin{tabular}{lrr}
\hline & Mtietê $h$ & Mtietê $m$ \\
\hline Média & 140,1857 & 187,7143 \\
Variância & 212,1998 & 353,1565 \\
Observações & 10 & 10 \\
gl & 9 & 9 \\
F & 0,600866 & \\
P(F<=f) uni-caudal & 0,22985 & \\
F crítico uni-caudal & 0,314575 & \\
\hline
\end{tabular}

Tabela 45: resultados do teste estatístico $F$ para o TF. Houve variação não significativa entre os informantes do Médio Tietê: $P>0,05$ e $F_{0}(0,60)>F_{c}(0,31)$

No primeiro teste, mesmo havendo a diferença tonal entre homens e mulheres dos informantes do Médio Tietê, tal assimetria não chega a ser expressiva, pois o valor$\mathrm{P}$ foi 0,60 ( $\mathrm{P}>0,05)$, não apresentando variação significativa.

Do mesmo modo, ocorreu com a comparação entre os controles, cujo valor P$0,36(\mathrm{P}>0,05)$ foi gerado.

\begin{tabular}{r|r}
\hline CONTR $\mathbf{h}$ & CONTR $\mathbf{~}$ \\
\hline 124 & 148 \\
\hline 90 & 244 \\
\hline 143 & 252 \\
\hline 69 & 206 \\
\hline 182 & 172 \\
\hline 88 & 220 \\
\hline 87 & 276 \\
\hline 119 & 176 \\
\hline 152 & 205 \\
\hline 122 & 212 \\
\hline
\end{tabular}

Tabela 46: comparação do Tom Final (TF) entre mulheres e homens do controle 
Teste-F: duas amostras para variâncias

\begin{tabular}{lrr}
\hline & \multicolumn{1}{c}{$S P h$} & \multicolumn{1}{c}{$S P m$} \\
\hline Média & 117,6 & 211,1 \\
Variância & 1219,378 & 1539,211 \\
Observações & 10 & 10 \\
gl & 9 & 9 \\
F & 0,79221 & \\
P(F<=f) uni-caudal & 0,367128 & \\
F crítico uni-caudal & 0,314575 & \\
\hline
\end{tabular}

Tabela 47: resultados do teste estatístico $F$ para o TF. Houve variação não significativa entre os informantes do controle: $P>0,05$ e $F_{0}(0,79)>F_{c}(0,31)$

Por fim, com as cidades portuguesas, também não houve diferenças entre os entrevistados, conforme visto nas tabelas 48 e 49, em que o valor-P gerado foi de 0,11 $(\mathrm{P}>0,05)$.

\begin{tabular}{r|r}
\hline PORT $\mathbf{h}$ & PORT $\mathbf{m}$ \\
\hline 215 & 187 \\
\hline 166 & 188 \\
\hline 150 & 166 \\
\hline 154 & 162 \\
\hline 138 & 184 \\
\hline 155 & 247 \\
\hline 212 & 221 \\
\hline 155 & 187 \\
\hline 139 & 291 \\
\hline 168 & 166 \\
\hline
\end{tabular}

Tabela 48: comparação do Tom Final (TF) entre mulheres e homens de Portugal

Teste-F: duas amostras para variâncias

\begin{tabular}{lrr}
\hline & $P O R T h$ & \multicolumn{1}{c}{ PORT $m$} \\
\hline Média & 165,3 & 199,9667 \\
Variância & 741,9123 & 1708,851 \\
Observações & 10 & 10 \\
gl & 9 & 9 \\
F & 0,434159 & \\
P(F<=f) uni-caudal & 0,114915 & \\
F crítico uni-caudal & 0,314575 & \\
\hline
\end{tabular}

Tabela 49: resultados do teste estatístico $F$ para o TF. Houve variação não significativa entre os informantes de Portugal: $P>0,05$ e $F_{0}(0,43)>F_{c}(0,31)$

Deste modo, vemos que o TF não apresenta variações em todos os casos apresentados, contudo, ao executarmos o teste $\mathrm{F}$ por meio das médias pareando as 
regiões, homens e mulheres apresentaram-se de maneira distinta do que foi observado. Assim como foi realizado com a análise de TM, colocar-se-á a tabela 50 como parâmetro das demais, 51,52 e 53 .

\begin{tabular}{r|r|r}
\hline Mtietê $\mathbf{~}$ & PORT $\mathbf{h}$ & CONTR $\mathbf{~}$ \\
\hline 148 & 215 & 124 \\
\hline 166 & 166 & 90 \\
\hline 161 & 150 & 143 \\
\hline 136 & 154 & 69 \\
\hline 140 & 138 & 182 \\
\hline 133 & 155 & 88 \\
\hline 123 & 212 & 87 \\
\hline 123 & 155 & 119 \\
\hline 134 & 139 & 152 \\
\hline 138 & 168 & 122 \\
\hline
\end{tabular}

Tabela 50: comparação do Tom Final (TF) entre homens do Médio Tietê, Portugal e controle

Teste-F: duas amostras para variâncias

\begin{tabular}{lrr}
\hline & Mtietê $h$ & CONTR $h$ \\
\hline Média & 140,1857 & 117,6 \\
Variância & 212,1998 & 1219,378 \\
Observações & 10 & 10 \\
gl & 9 & 9 \\
F & 0,174023 & \\
P(F<=f) uni-caudal & 0,007851 & \\
F crítico uni-caudal & 0,314575 & \\
\hline
\end{tabular}

Tabela 51: resultados do teste estatístico $F$ para o TF. Houve variação significativa entre os informantes masculinos do Médio Tietê e o controle: $P<0,05$ e $F_{0}(0,17)<F_{c}(0,31)$

Na tabela 51, o teste $\mathrm{F}$ verifica que há uma diferença significativa entre os valores, mesmo considerando que a soma das médias do TF do Médio Tietê seja mais grave do que o controle. O valor-P é $0,007(\mathrm{P}<0,05)$.

\begin{tabular}{lrr}
\multicolumn{3}{l}{ Teste-F: duas amostras para variâncias } \\
\hline & PORT $h$ & Mtietê $h$ \\
\hline Média & 165,3 & 140,1857 \\
Variância & 741,9123 & 212,1998 \\
Observações & 10 & 10 \\
gl & 9 & 9 \\
F & 3,496292 & \\
P(F<=f) uni-caudal & 0,03812 & \\
F crítico uni-caudal & 3,178893 \\
\hline
\end{tabular}

Tabela 52: resultados do teste estatístico $F$ para o TF. Houve variação significativa entre os informantes masculinos do Médio Tietê e Portugal: $P<0,05$ e $F_{0}(3,49)>F_{c}(3,17)$ 
Comparando o Médio Tietê com Portugal, também há uma variação significativa entre os dados, com P-0,03 $(\mathrm{P}<0,05)$.

\begin{tabular}{lrr}
\multicolumn{3}{l}{ Teste-F: duas amostras para variâncias } \\
\hline & PORT $h$ & CONTR $h$ \\
\hline Média & 165,3 & 117,6 \\
Variância & 741,9123 & 1219,378 \\
Observações & 10 & 10 \\
gl & 9 & 9 \\
F & 0,608435 & \\
P(F<=f) uni-caudal & 0,235347 \\
F crítico uni-caudal & 0,314575 \\
\hline
\end{tabular}

Tabela 53: resultados do teste estatístico $F$ para o TF. Houve variação não significativa entre os informantes masculinos do controle e Portugal: $P>0,05$ e $F_{0}(0,60)>F_{c}(0,31)$

E, por fim, entre Portugal e o controle não houve variação significativa, sendo P$0,23(\mathrm{P}>0,05)$.

Assim, observando os números expressos na tabela 50, percebemos que os entrevistados do Médio Tietê têm o TF mais agudo do que o controle, e mais grave do que os de Portugal. Além disso, o teste-F demonstra que há diferenças expressivas entre eles, corroborando a maioria dos testes anteriores.

$\mathrm{Na}$ próxima etapa, nas tabelas 55, 56 e 57, as mulheres trarão resultados semelhantes aos masculinos, em que, contrapondo as médias dos falares do Médio Tietê com os de Portugal e controle, haverá variações significativas, porém, ao serem comparados os valores de Portugal e as do controle, não.

\begin{tabular}{r|r|r}
\hline Mtietê $\mathbf{m}$ & PORT $\mathbf{m}$ & CONTR $\mathbf{m}$ \\
\hline 176 & 187 & 148 \\
\hline 190 & 188 & 244 \\
\hline 205 & 166 & 252 \\
\hline 164 & 162 & 206 \\
\hline 158 & 184 & 172 \\
\hline 210 & 247 & 220 \\
\hline 180 & 221 & 276 \\
\hline 212 & 187 & 176 \\
\hline 199 & 291 & 205 \\
\hline 217 & 166 & 212 \\
\hline
\end{tabular}

Tabela 54: comparação do Tom Final (TF) entre mulheres do Médio Tietê, Portugal e controle 
Teste-F: duas amostras para variâncias

\begin{tabular}{lrr}
\hline & Mtietê $m$ & CONTR $m$ \\
\hline Média & 191,2714 & 211,1 \\
Variância & 426,6143 & 1539,211 \\
Observações & 10 & 10 \\
gl & 9 & 9 \\
$\mathrm{~F}$ & 0,277164 & \\
$\mathrm{P}(\mathrm{F}<=\mathrm{f})$ uni-caudal & 0,034768 & \\
F crítico uni-caudal & 0,314575 & \\
\hline
\end{tabular}

Tabela 55: resultados do teste estatístico $F$ para o TF. Houve variação significativa entre as informantes do Médio Tietê e controle: $P<0,05$ e $F_{0}(0,27)<F_{c}(0,31)$

Iniciando a comparação com as informantes do Médio Tietê e o controle, apresentou-se variação significativa, com $\mathrm{P}-0,03(\mathrm{P}<0,05)$.

\begin{tabular}{lrr}
\multicolumn{3}{l}{ Teste-F: duas amostras para variâncias } \\
\hline & PORT m & Mtietê $m$ \\
\hline Média & 199,9667 & 191,2714 \\
Variância & 1708,851 & 426,6143 \\
Observações & 10 & 10 \\
gl & 9 & 9 \\
F & 4,00561 & \\
P(F<=f) uni-caudal & 0,025392 \\
F crítico uni-caudal & 3,178893 \\
\hline
\end{tabular}

Tabela 56: resultados do teste estatístico $F$ para o TF. Houve variação significativa entre as informantes do Médio Tietê e Portugal: $P<0,05$ e $F_{0}(4,00)>F_{c}(3,17)$

Ao contrapor os dados de Médio Tietê e Portugal, novamente temos uma variação significativa, pois o valor-P é de $0,02(\mathrm{P}<0,05)$. Mas ao compararmos os valores de Portugal e do controle, teremos um P-0,43 ( $\mathrm{P}>0,05)$, demonstrando que não existe diferença expressiva entre os dialetos.

\begin{tabular}{lrr}
\multicolumn{3}{l}{ Teste-F: duas amostras para variâncias } \\
\hline & PORT $m$ & CONTR $m$ \\
\hline Média & 199,9667 & 211,1 \\
Variância & 1708,851 & 1539,211 \\
Observações & 10 & 10 \\
gl & 9 & 9 \\
F & 1,110212 & \\
P(F<=f) uni-caudal & 0,439394 & \\
F crítico uni-caudal & 3,178893 \\
\hline
\end{tabular}

Tabela 57: resultados do teste estatístico $F$ para o TF. Houve variação não significativa entre as informantes do Médio Tietê e Portugal: $P>0,05$ e $F_{0}(1,11)>F_{c}(3,17)$ 
Analisando de modo geral, o teste-F das médias dos dados femininos das tabelas 55 e 56 trouxe resultados distintos dos estudados anteriormente, por ter sido quase unânime o fato de as variações não serem significativas nos testes de Dunnett e ANOVA. Outro fator avaliado foi os valores apresentados pelos tons: tendo em vista as somas das médias dos valores referentes ao controle e de Portugal, estas são superiores aos do dialeto caipira, estabelecendo tecnicamente que, em relação ao TF, as mulheres coletadas para o controle e as informantes portuguesas são mais agudas que as do Médio Tietê.

Após encerrarmos os cálculos estatísticos, vemos novamente que não há uma similaridade ou disparidade plena entre os resultados, assim como nos estudos de TM, pois temos uma base de dados que nos mostra que é possível haver diferenças expressivas entre os informantes ou não. Sendo assim, confirmamos, dentro do exame de TF, que as regiões do Médio Tietê, de Portugal e o controle não se distinguem com caracterizações próprias, havendo, em diversas vezes, similitudes dentro de suas entoações.

Ou seja, o que se vê claramente são os resultados do teste de Dunnett, e percebese que Capivari e Pirapora do Bom Jesus apresentam valores semelhantes com o TF < $150 \mathrm{~Hz}$; Itu, Piracicaba, Santana de Parnaíba, Vila Real e o controle com valores $\geq 150$ Hz; e Tietê, Braga e Bragança aproximando-se de 200Hz. De fato, é possível equiparar alguns números, como Itu, Porto Feliz e Vila Real: a diferença entre Itu e Porto Feliz é de apenas $0,05 \%$. É certo que as cidades têm apenas $26,7 \mathrm{~km}$ de distância entre si, no entanto, a diferença entre elas e Vila Real é de $0,52 \%$ e $0,57 \%$, respectivamente; enquanto a diferença entre Capivari e Tietê (28 km de distância) é de 31,1\%.

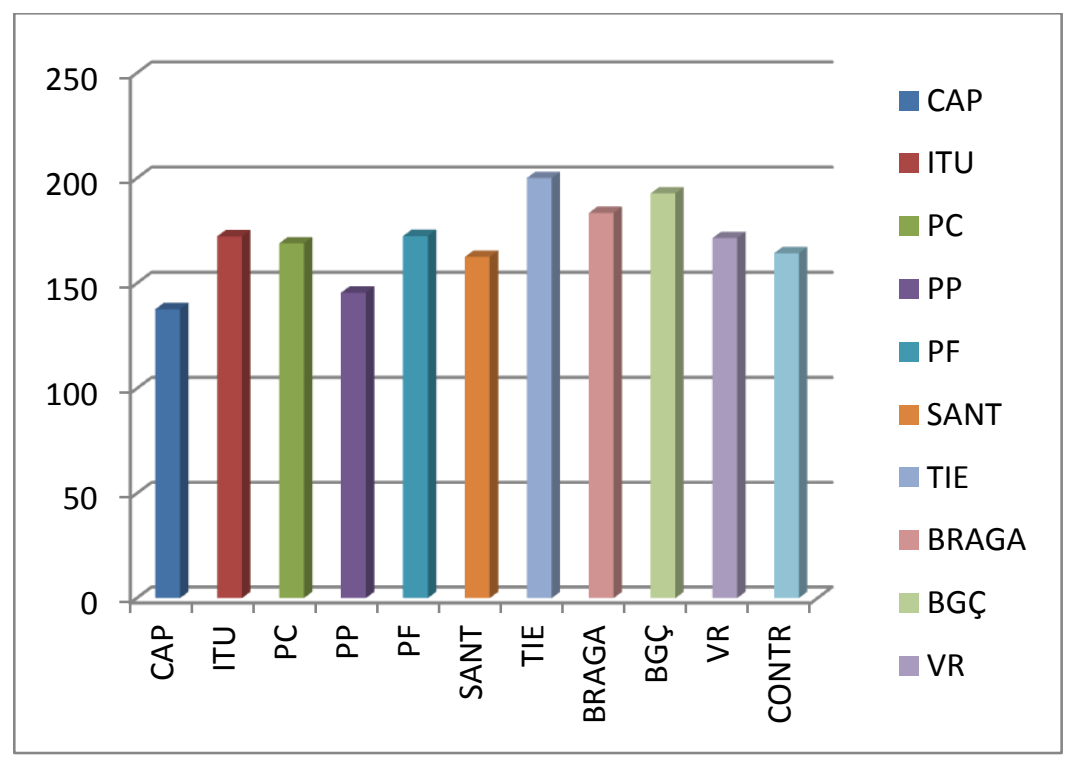

Gráfico 7: comparação do Tom Final (TF) medido em Hertz (linha vertical) entre as cidades do Médio Tietê, Portugal e o controle (linha horizontal) 
Ao se separarem os dados de homens e mulheres, nota-se como o resultado do TF das informantes de Tietê acentua-se por se apresentarem mais agudas do que os outros exemplares. Ao mesmo tempo em que os dados masculinos de Itu, Piracicaba e Vila Real coincidem-se.

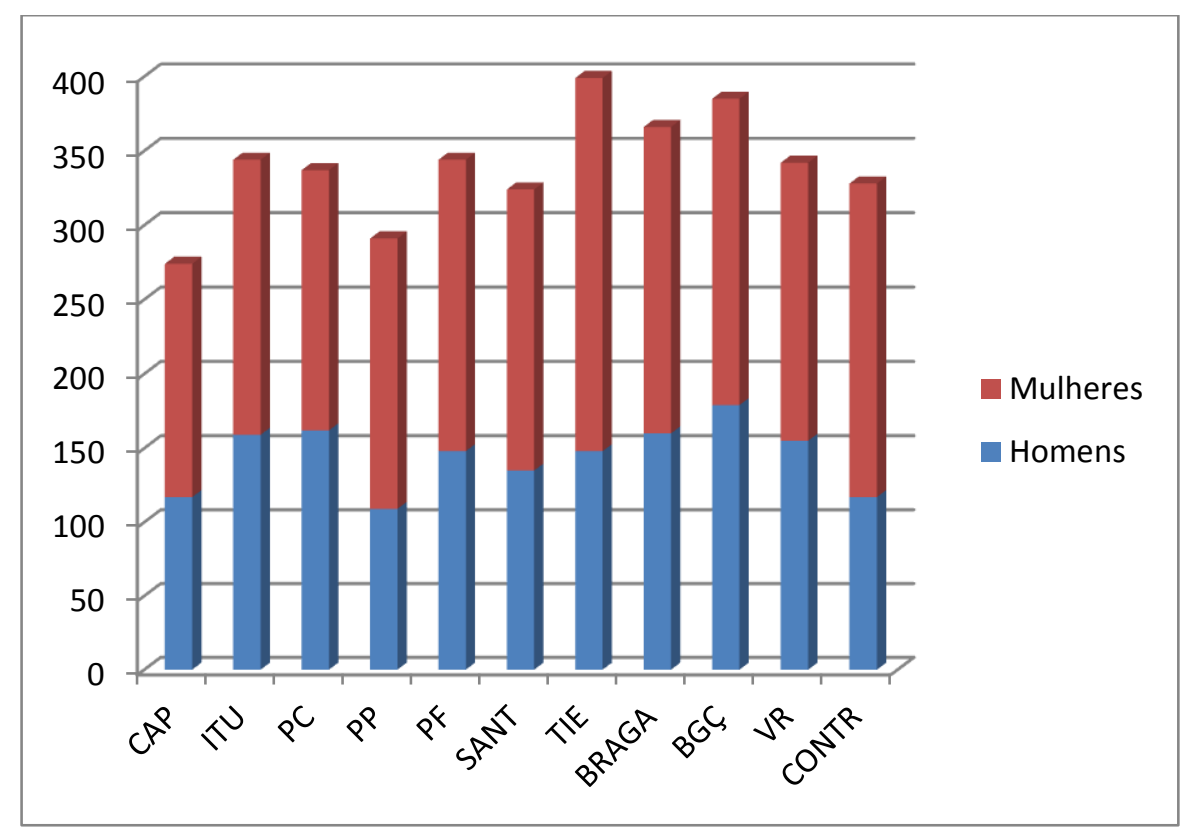

Gráfico 8: comparação de TF entre categorias - mulheres e homens - em unidade cps medido em Hertz (linha vertical) entre as cidades do Médio Tietê, Portugal e o controle (linha horizontal)

\subsection{O tom médio e o tom final em conjunto}

Embora não tenha havido diferenças que caracterizassem de forma única o TM e TF estudados separadamente, o tratamento dos valores demonstrou que existe disparidade entre o dialeto caipira e o controle quando esses resultados são justapostos, porém, há similaridade entre os falantes do Médio Tietê e Portugal.

Isso se deve ao fato de as diferenças de TM e TF existirem mesmo não sendo expressivas em relação ao controle, pois a finalização deste costuma agir de modo sempre autêntico, ao contrário da das cidades do Médio Tietê e Portugal. Desta forma, o TF desenvolvido pelos informantes da fala neutra tem uma finalização uniforme independentemente do gênero sexual, com valores de TM mais altos do que de TF. Já os falantes do dialeto caipira são mais distintos, não mantendo sequer uma regularidade, conforme visto no gráfico 9: os totens referem-se aos coeficientes gerados a partir da divisão das médias de TM e TF dos informantes. Percebe-se, no conjunto de todos os totens, que há uma uniformização de dados do controle. 


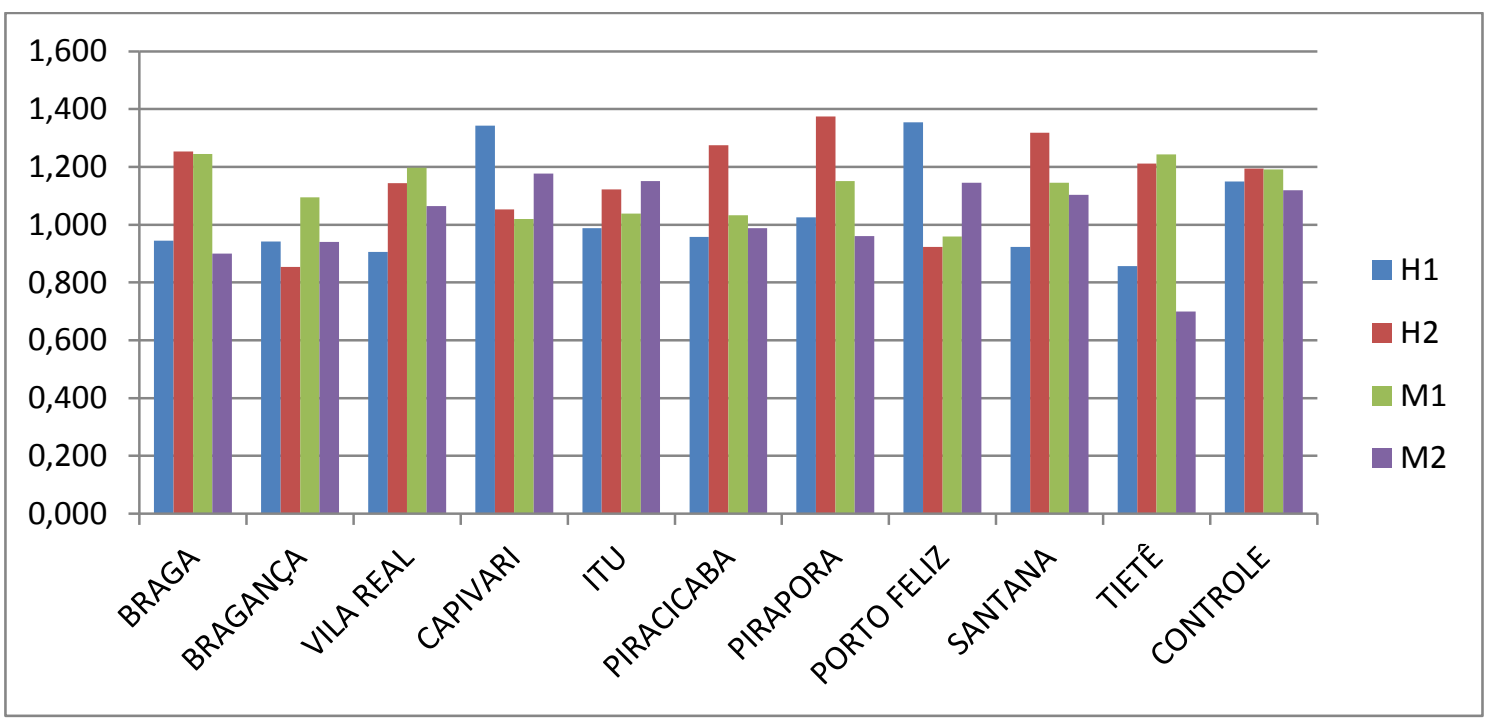

Gráfico 9: comparação de coeficientes entre os informantes das cidades. Na linha horizontal, há o nome das cidades; na horizontal, as médias geradas a partir do cálculo do coeficiente do TM e TF de cada informante. Na legenda, $\mathrm{H}$ significa Homem e $M$, mulher

Embora saibamos que a regularidade apresentada pelo controle refere-se a uma padronização do meio telejornalístico, deve-se levar em consideração a prática majoritária de finalização autêntica que ocorre entre os falantes de língua portuguesa no Brasil, conforme identificado por Ferreira Netto e Baz (2011) e nos trabalhos de Costa (2011).

Por isso, comparando os valores numéricos expressos nas tabelas 2 e 28, vemos que entre os informantes das regiões estudadas ocorrem finalizações plagais e autênticas, todavia, o que sobressai são as plagais.

Para a primeira análise, obteve-se uma média geral de TM e TF a partir dos dados já apresentados nas tabelas 2 e 28. As médias de TM e TF expressas na tabela 58 geram o gráfico 11. Vejamos:

\begin{tabular}{l|r|c}
\hline Cidades & \multicolumn{1}{c|}{ TM } & \multicolumn{1}{c}{ TF } \\
\hline MÉDIO TIETÊ & 176,33 & 165,72 \\
\hline CONTROLE & 190,5 & 164,35 \\
\hline PORTUGAL & 188,51 & 182,63 \\
\hline
\end{tabular}

Tabela 58: comparação entre os informantes do Médio Tietê, Portugal e controle com valores medidos em Hertz

Em média, a diferença percentual entre o TM e o TF do controle é de 13,7\%, enquanto para os falantes do dialeto caipira é de $6 \%$, e os de Portugal de 3,2\%, dando a eles a característica de finalização plagal. 


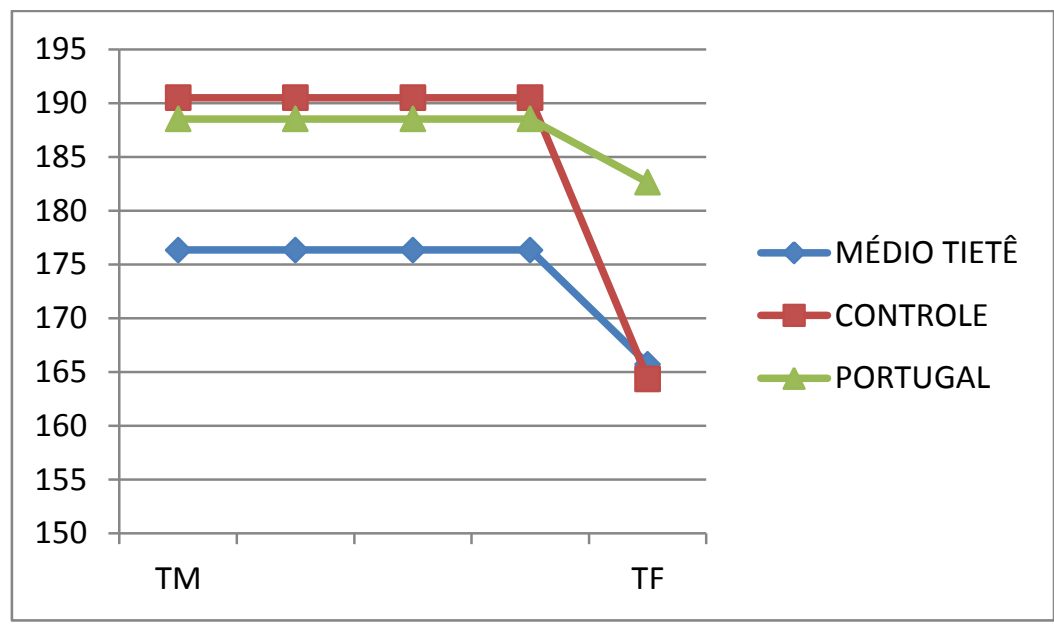

Gráfico 10: comparação entre as finalizações dos falantes do Médio Tietê, Portugal e controle. $O$ eixo vertical refere-se às médias medidas em Hertz, e a horizontal refere-se ao Tom Médio e ao Tom Final decorrentes das falas

Como nos estudos de TM e TF houve a preocupação de estudar a variante gênero, também o é necessário realizar neste item. Analisando primeiramente os informantes masculinos, as tabelas 6 e 32 auxiliaram a visualizar os dados abaixo:

\begin{tabular}{l|r|l}
\hline Cidade & TM masc. & TF \\
\hline MÉDIO TIETÊ & 154,9 & 140,2 \\
\hline PORTUGAL & 165,2 & 165,3 \\
\hline CONTROLE & 137,7 & 117,6 \\
\hline
\end{tabular}

Tabela 59: comparação entre os informantes masculinos do Médio Tietê, Portugal e controle com valores medidos em Hertz

Nesse conjunto de dados, as médias apresentadas pelas cidades de Portugal demonstraram ser acentuadamente plagais, tendo em vista que a diferença percentual entre o TM e o TF foi de apenas $0,06 \%$. Em se tratando do Médio Tietê, o público masculino apresentou a diferença de $9,4 \%$, enquanto o controle foi de $14,5 \%$.

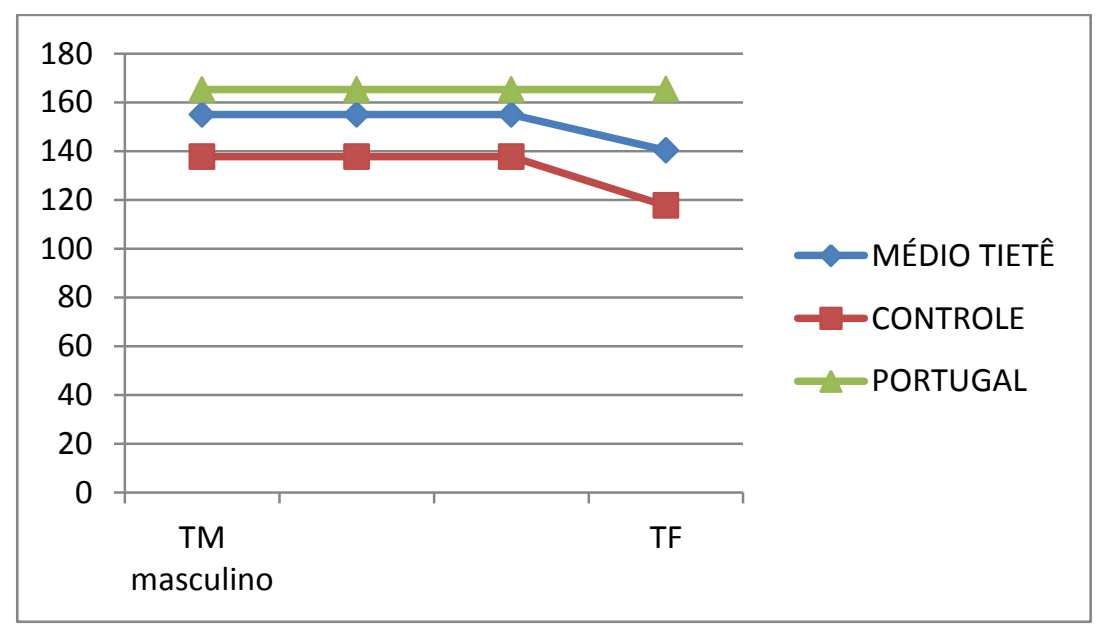

Gráfico 11: comparação entre as finalizações dos falantes masculinos do Médio Tietê, Portugal e controle. $O$ eixo vertical refere-se às médias medidas em Hertz, e a horizontal refere-se ao Tom Médio e ao Tom Final decorrentes das falas 
Enquanto a tabela 59 discrimina os valores em TF e TM, o gráfico 12 mostra que a finalização dos dados de Médio Tietê não é tão acentuada quanto o controle, havendo uma tendência a uma finalização mais grave. $O$ teste $\chi^{2}$ reitera a diferenciação ao gerar o valor $\mathrm{P}-0,01(\mathrm{P}<0,05)$. O mesmo ocorre com o público feminino:

\begin{tabular}{l|r|l}
\hline Cidade & TM - fem. & TF \\
\hline MÉDIO TIETÊ & 197,8 & 191,3 \\
\hline PORTUGAL & 211,8 & 199,9 \\
\hline CONTROLE & 243,3 & 211,1 \\
\hline
\end{tabular}

Tabela 60: comparação entre os informantes femininos do Médio Tietê, Portugal e controle com valores medidos em Hertz

A diferença percentual do TM e TF entre as mulheres de Portugal e do Médio Tietê também mostra uma finalização plagal notável, pois as mulheres do Médio Tietê apresentaram $3,2 \%$ de diferença; enquanto as portuguesas têm 5,6\%; e as do controle, $13,2 \%$.

Assim sendo, o gráfico 13 expõe que as mulheres do Médio Tietê e de Portugal têm o tom final mais grave do que as de SP, gerando uma diferença bem significativa pelo teste $\chi^{2}(0,0007 ; \mathrm{P}<0,5)$, denotando a elas uma característica de finalização plagal.

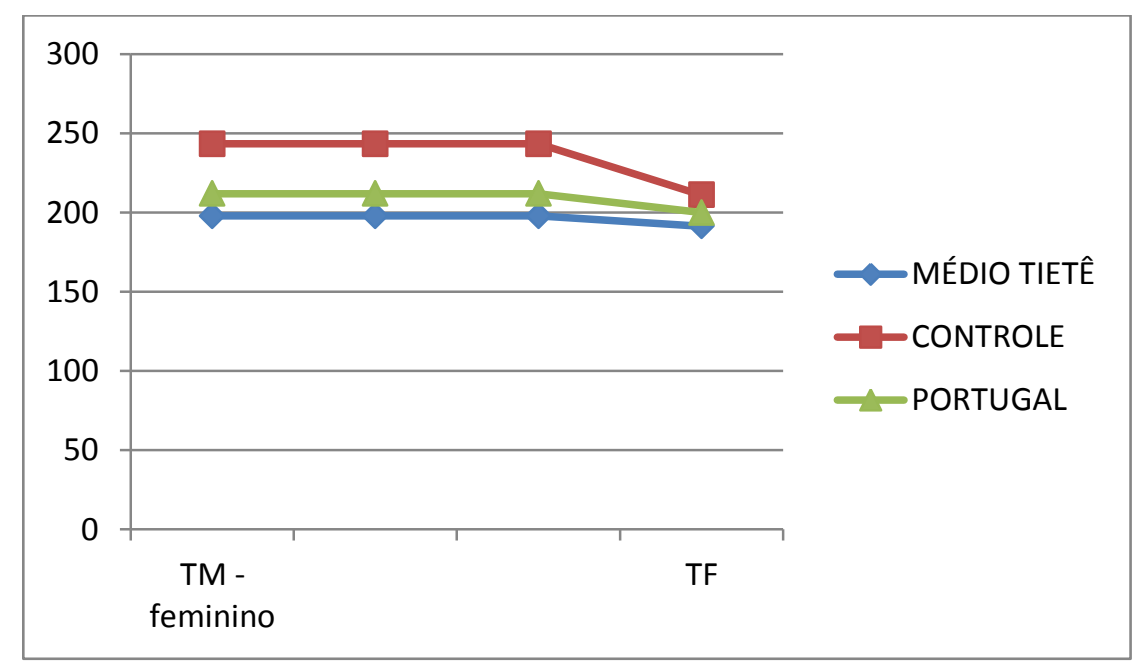

Gráfico 12: comparação entre as finalizações dos falantes femininos do Médio Tietê, Portugal e controle. $O$ eixo vertical refere-se às médias medidas em Hertz, e a horizontal refere-se ao Tom Médio e o Tom Final decorrente das falas

De modo geral, nota-se, pela diferença percentual, que os valores do controle praticamente repetem-se, ficando em volta de 13\%. As demais cidades, por sua vez, apresentaram o valor próximo a 5\%, excetuando os exemplos masculinos referentes ao gráfico 11: mesmo que as cidades de Portugal tenham se caracterizado pelas finalizações plagais $(\geq 0 \%)$, o resultado obtido pelas do Médio Tietê ficam abaixo dos 10\%. O fato é que a diferença percentual entre os homens do controle e os do Médio 
Tietê é de $35,1 \%$, o que nos faz entender que a finalização dos falantes do dialeto caipira apresenta-se majoritariamente como plagais, por não apresentarem a finalização tão acentuada quanto a do controle.

Para ilustrar como são representadas graficamente as entoações frasais, foram escolhidos 6 gráficos produzidos pelo ExProsodia. Os exemplos selecionados dos portugueses e dos falantes do DC trazem finalizações plagais, enquanto o controle possui a finalização autêntica. Observemos as linhas de $\mathrm{F}_{0}$, TM e finalização:

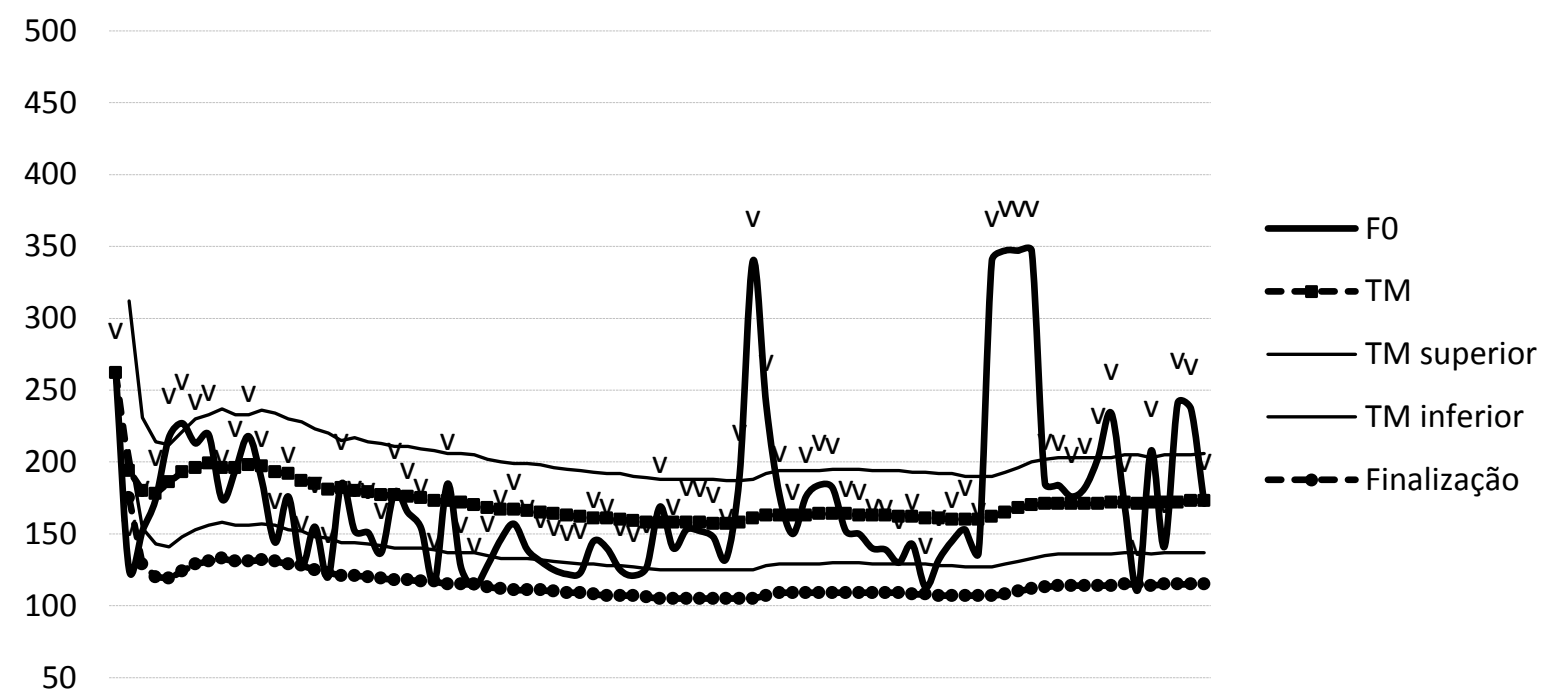

Gráfico 13: exemplo da entoação frasal masculina (H1/FR1) de Itu. Frase: “A juventude era uma coisa gostosa, né... nóis tinha a nossa praça, nóis frequentava a praça, nóis andava pra praça, arrumava namorada, e assim foi indo... tinha o coreto, tinha a nossa banda união que era bastante afamada, e assim... tocando a vida pra frente." A média do TM é 173 e do TF é 171

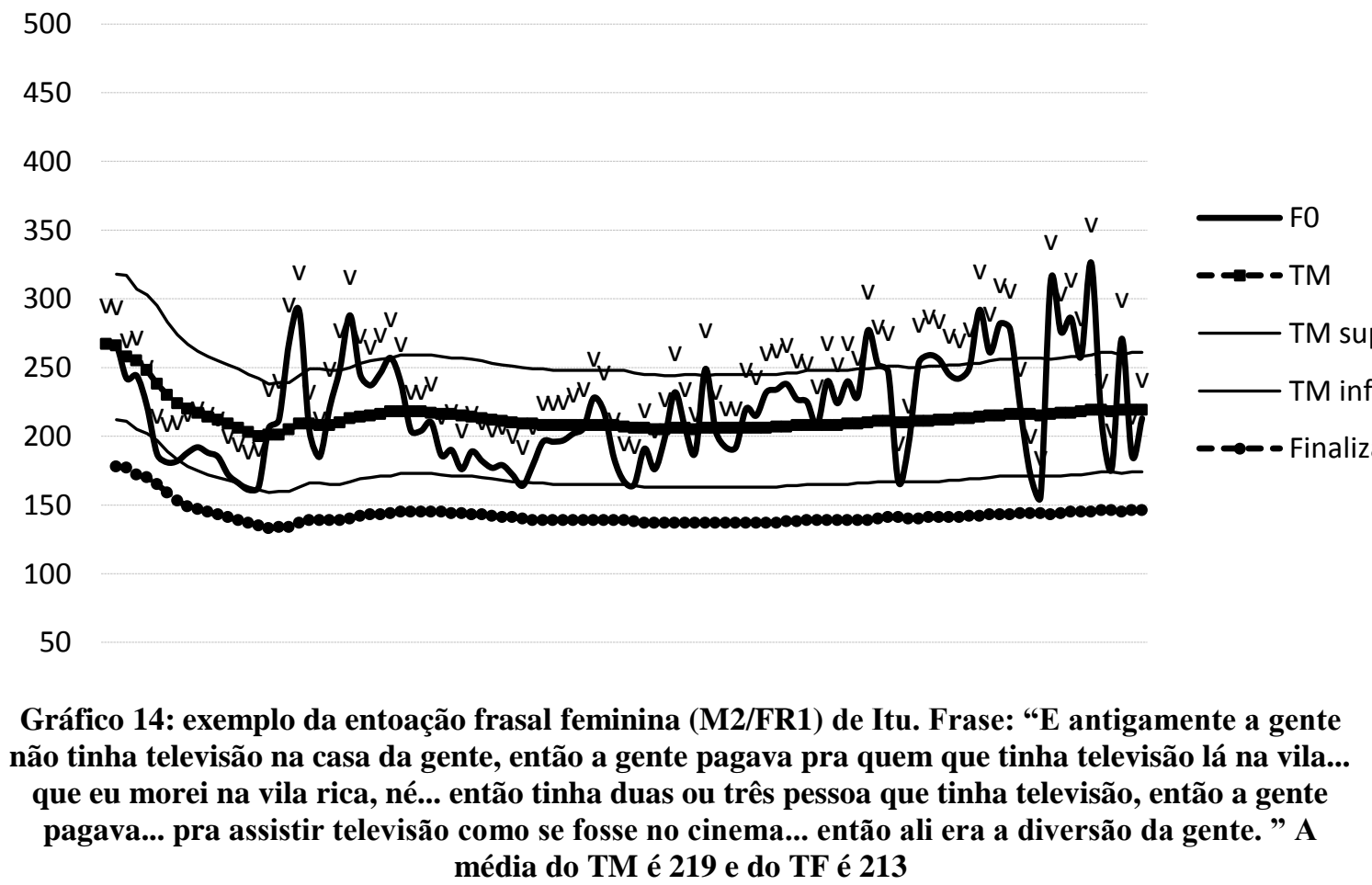




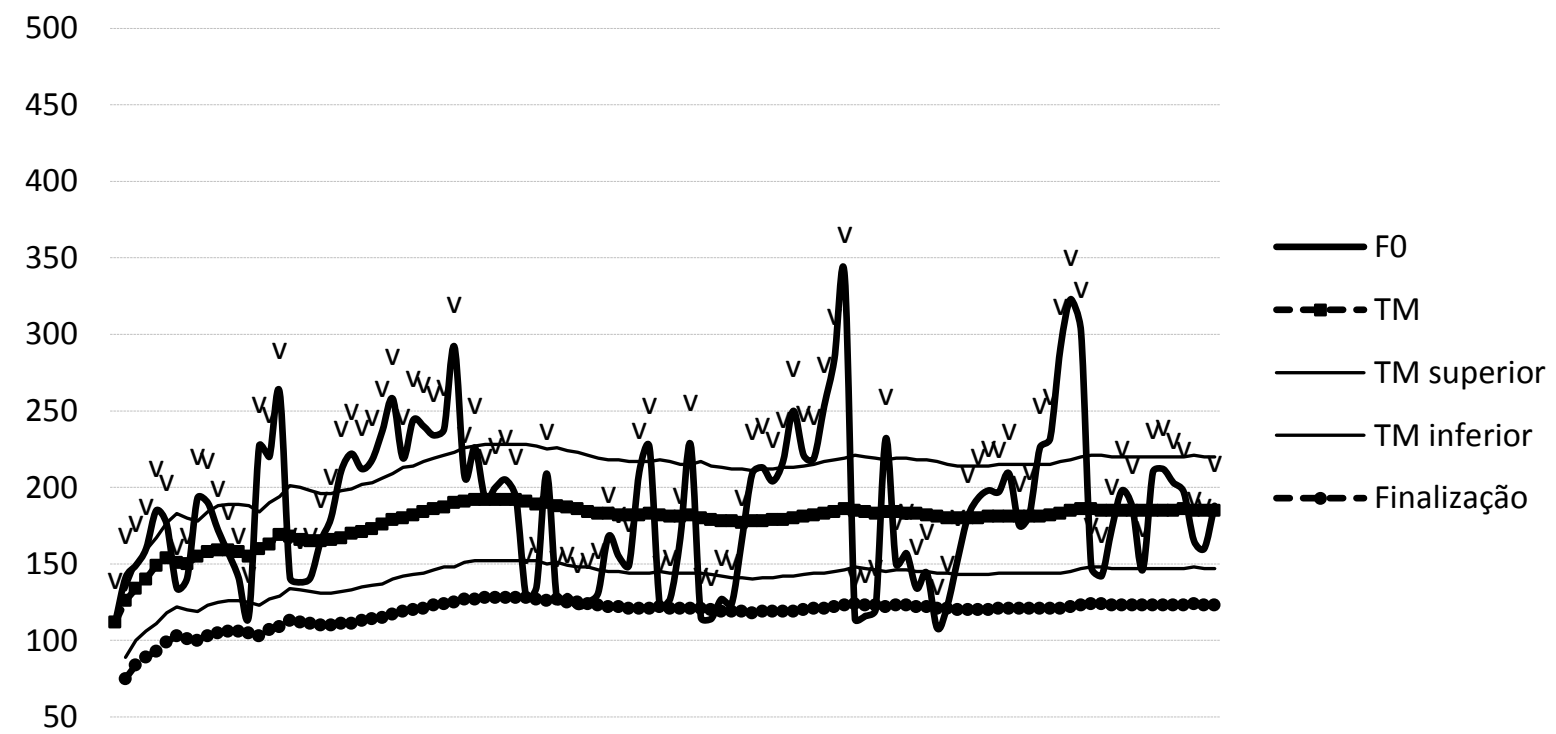

Gráfico 15: exemplo da entoação frasal masculina (H1/FR4) de Bragança. Frase: "Trabalhar, tu o que que queria... estudar até a quarta classe e depois trabalhar... comecei a trabalhar de carpinteiro, ué, fiz carpintaria depois fiz ele... a escola no meu tempo era rapazes prum lado e raparigas pro outro... e não havia misturas." A média do TM é 185 e do TF é 188

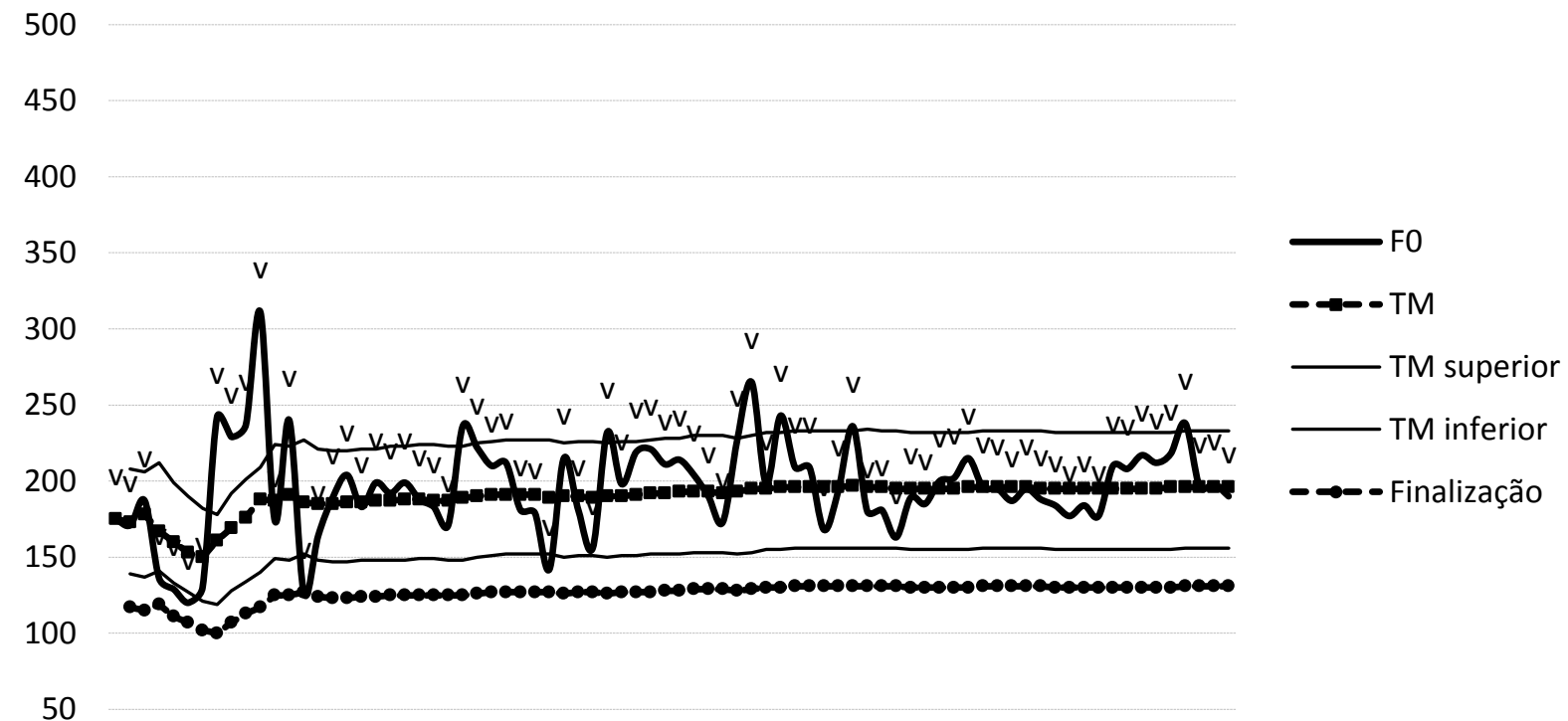

Gráfico 16: exemplo da entoação frasal feminina (M1/FR3) de Bragança. Frase: "Era a escola... Na escola, a gente hoje na escola tem tudo... antigamente a gente estava descalça e com frio e aprendias... e as professoras carregavam numas pessoas e hoje num se pode bater num filho." A média do TM é 196 e do TF é 190 


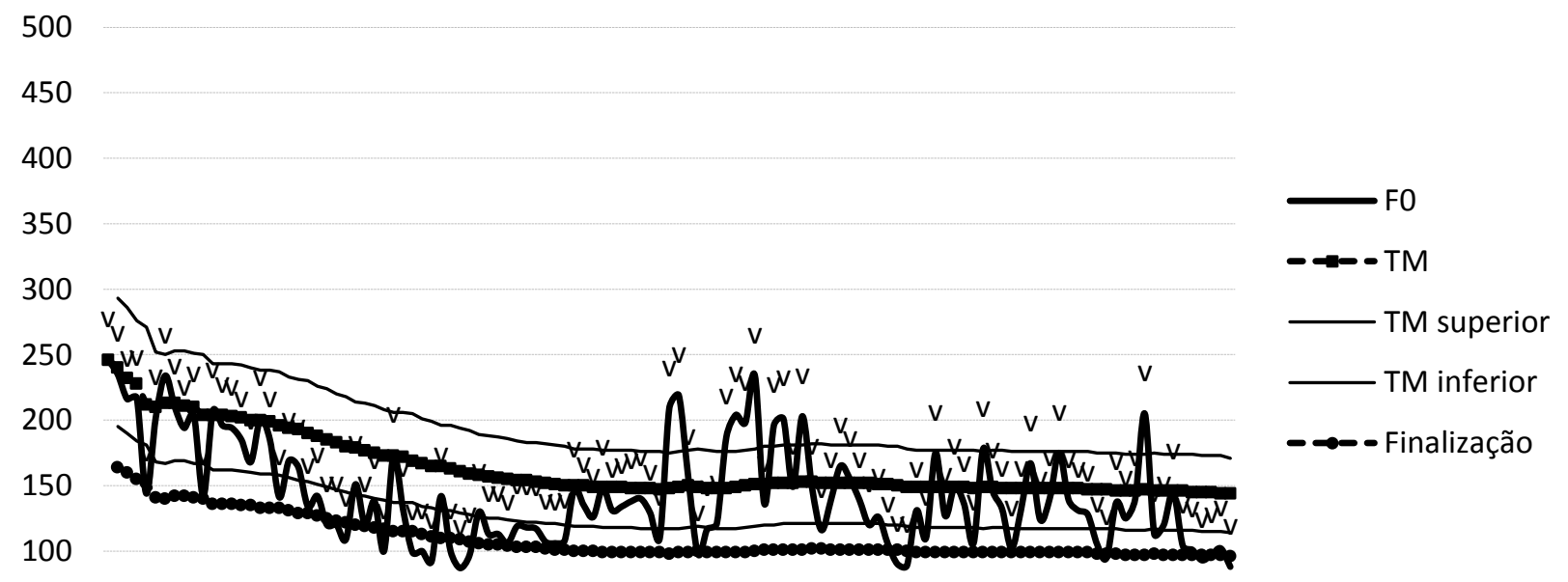

50

Gráfico 17: exemplo da entoação frasal masculina (M1/FR3) do Controle. Frase: "Administração de empresas é o curso que tem o maior número de alunos no estado, são duzentos e vinte mil, a gente fala agora do vestibular, e um dos motivos que atrai tanta gente é que administração é um... é um curso curinga, né... dá pra trabalhar com recursos humanos, com marketing, virar executivo, abrir o seu próprio negócio, são muitas as opções." A média do TM é 144 e do TF é 88

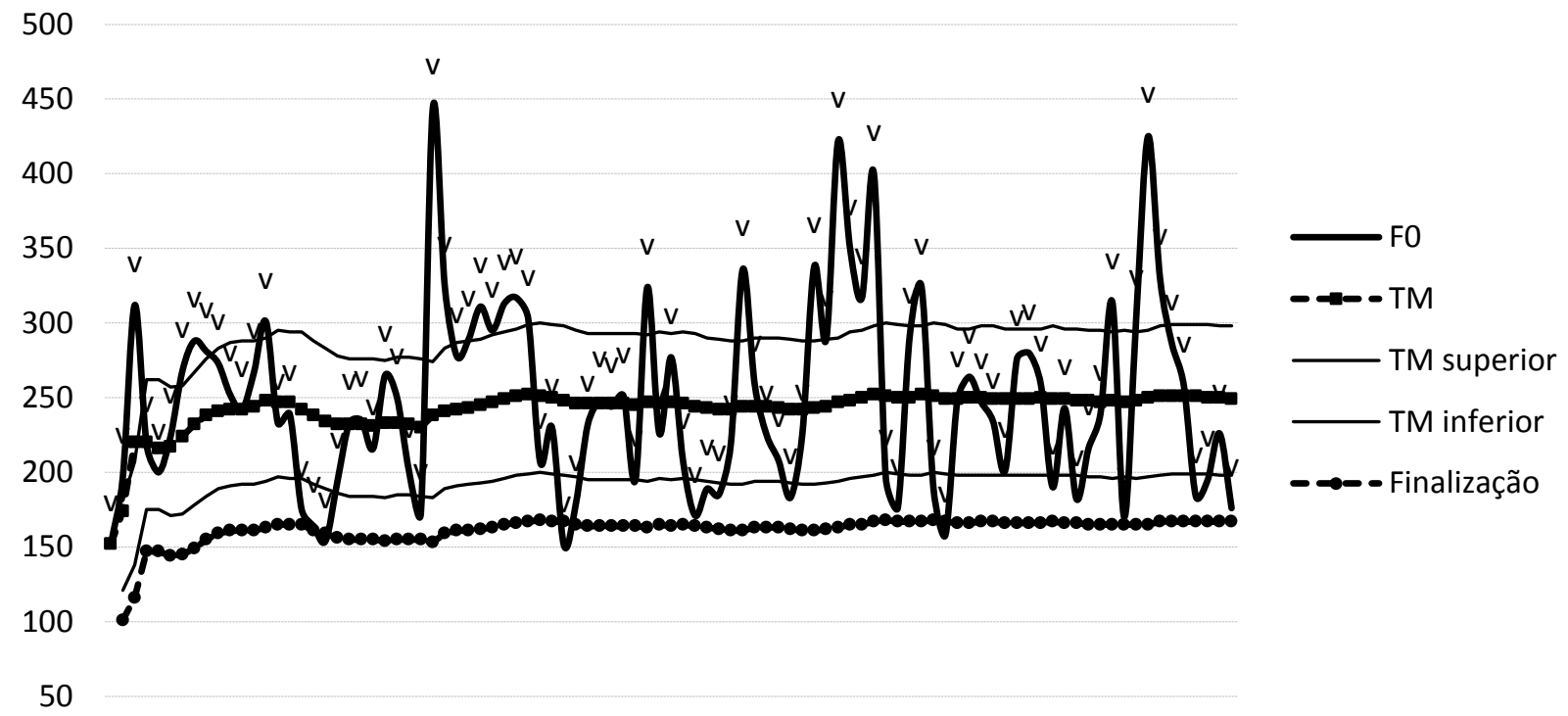

Gráfico 18: exemplo da entoação frasal feminina (M2/FR3) do Controle. Frase: "É sim... um administrador pode dirigir uma empresa, cuidar do marketing, trabalhar com sustentabilidade, apostar num mercado financeiro, formar uma carreira abrangente e uma formação ampla... nos quatro anos de curso o aluno estuda de filosofia a matemática. " A média do TM é 249 e do TF é

176

Nota-se que os gráficos representam a fala de um homem e de uma mulher de cada região (Itu, do Médio Tietê; e Bragança, de Portugal) e do controle. Embora as linhas que reproduzam as médias de TM e de finalização sejam visualmente regulares em todos os casos, devemos atentar para a representação de $\mathrm{F}_{0}$ : avaliando os gráficos 13 
a 16 , vemos que a última linha da curva de $\mathrm{F}_{0}$ se encerra nas proximidades da linha de TM, demarcada com quadrados; enquanto os gráficos 17 e 18 trazem essa mesma linha terminando perto da de finalização, identificada com pequenos pontos. Embora o gráfico 15 tenha um TF maior do que o TM, nota-se que a linha de $\mathrm{F}_{0}$ encerra-se atingido a de TM. Essa característica apontada nos gráficos 13 a 16 é o que constitui a finalização plagal, apresentada na maioria das frases analisadas para esta tese, ao contrário das frases do controle, em que os exemplos têm finalização autêntica.

Portanto, chegamos à conclusão de que a entoação caipira é caracterizada por ser sua finalização majoritariamente plagal. 
Considerações

Finais 


\section{Considerações finais}

Esta tese foi iniciada mostrando que o dialeto caipira resguarda variações linguísticas que se mantêm na nossa Língua Portuguesa.

Sabendo-se que o desenvolvimento de um idioma está intimamente ligado à sua História, compreendemos que os processos pelos quais passaram nossos colonos e colonizadores fizeram com que muitos traços se mantivessem presentes até os dias atuais. Em outras palavras, considerando as fases de isolamento, os hábitos criados e mantidos durante séculos (há de se lembrar do depoimento de um dos informantes de Pirapora do Bom Jesus ao afirmar que, até pouco tempo, ainda havia construções "da época dos índios” em sua cidade), entende-se que muitas variações linguísticas também foram conservadas nessas localidades.

Da mesma forma, há de se considerar que a gramática, responsável pela sistematização e fixação do uso padronizado da língua (BORBA, 1975, p.65), somente foi introduzida na vida das pessoas comuns, tanto no Brasil quanto em Portugal, quando a escola realmente começou a fazer parte de seus cotidianos. Essa ação foi promovida pela mudança da política internacional, impulsionada pela filosofia iluminista que marcou o século XVIII, fazendo com que os governantes se preocupassem e começassem a oferecer educação indistintamente a todos. Tal ação - decretada em 1774 por Marquês de Pombal em Portugal, e fixada pela Constituição de 1824 no Brasil - iniciou-se efetivamente no final do século XIX, mas obteve maior sucesso em meados do XX em ambos os países (GARCIA; DA SILVA, 2012; FERREIRA, 2009; RAMOS, 1988). Por isso, levando-se em consideração que: a maior parte de nossos colonizadores foi analfabeta; nossa educação tem somente cerca de um século; o Brasil ainda possui 13,2 milhões de brasileiros analfabetos (IBGE, 2012), vemos que a prática educacional em nosso país ainda está em desenvolvimento.

O caso é que esses fatos têm influência sobre os processos linguísticos, e podem ser determinantes ao estabelecer diferenças na articulação das palavras e produção da fala. Neste estudo, especificamente, percebemos que, nas regiões do Médio Tietê, não apenas o léxico preserva caracterizações pertencentes a períodos mais remotos, mas também a entoação. Pesquisas desenvolvidas por Ferreira Netto (2010), Baz (2011), Costa (2011), e, agora, esta tese, dão pistas de que o estado natural da entoação se daria por meio de finalizações plagais, traço que desaparece quando os informantes possuem instrução. 
Por causa desses resultados, uma das hipóteses levantadas é que, durante o processo de aquisição da escrita, a entoação também tende a ser modificada devido à dinâmica realizada em sala de aula.

Segundo Barros (1994), professores alfabetizadores monitoram sua fala e costumam alterar o ritmo e entoação para que os alunos apropriem-se de diversas informações e comecem a atender à norma culta. Desta forma, os valores fonológicos são comprometidos quando se ressaltam enfaticamente a presença de sílabas, o uso de clíticos de forma geral (artigos, pronomes oblíquos átonos, preposições, conjunções), ou a produção de interrogativas. De acordo com Kato (1986), a fala é segmentada, construída por unidades linguísticas em uma cadeia contínua de sinais acústicos; todavia, uma pessoa em vias de alfabetização ainda não tem essa noção, e costuma entender uma palavra como frase fonológica. Isto é, a frase é compreendida como um único elemento, não havendo fronteiras estabelecidas ortograficamente (CUNHA; MIRANDA, 2009, p.128).

Conforme Cagliari (2002), a noção de que a língua é constituída por um conjunto de sistemas diferentes é construída a partir do momento em que uma criança, em vias de alfabetização, intensifica o contato com o texto escrito e internaliza a norma. Em estudo com adultos semialfabetizados (FERREIRA, 2009), por exemplo, as mesmas características de hiper e hipossegmentação de vocábulos que se observam nas crianças também ocorrem neles, o que se justifica pela influência prosódica (ABAURRE, 1991; CUNHA, 2004). Sendo assim, entende-se que, a partir do momento em que o falante tem conhecimento suficiente sobre os processos gramaticais, os constituintes prosódicos ${ }^{16}$ são reconstruídos.

Ou seja, por meio da alfabetização, formam-se variações entoacionais na prosódia, sendo possível identificar diferenças entre as falas de pessoas plenamente alfabetizadas e as de baixa ou nenhuma escolaridade.

Situação analisada por Ferreira Netto e Consoni (2008), por meio dos estudos sistematizados foi possível identificar que, na oralidade dos falantes de língua portuguesa do Brasil, o TM costuma não apresentar valores fixos ao contrário do TF. Em se tratando do TM, o fato de ele sofrer alterações é compreensível, pois, conforme já explicado no capítulo 3, cada falante faz a manutenção do seu próprio tom durante a fala, todavia, os estudos envolvendo o TF demonstram que há uma influência social no modo de finalização das frases.

\footnotetext{
${ }^{16}$ De acordo com Nestor e Vogel (1994), os constituintes prosódicos são: sílaba $(\sigma)$, pé $(\Sigma)$, palavra fonológica $(\omega)$, grupo clítico $(C)$, frase fonológica $(\varphi)$, frase entoacional (I) e enunciado $(U)$.
} 
Conforme demonstrado no capítulo 2, o canto gregoriano e as canções da tribo Kaiowá possuem um ponto em comum que é a cadência plagal. Trazendo tal característica para os estudos de entoação, foi visto que as falas dos portugueses apresentaram a mesma característica, tanto quanto os informantes do dialeto caipira. Ao contrário, porém, do controle trabalhado nesta tese, constituído por jornalistas do programa SPTV da Rede Globo, que produziram em todas as falas a finalização autêntica.

Seguindo o mesmo princípio, Costa (2011) verificou que as mulheres corumbaenses semialfabetizadas ou analfabetas e as índias guatós costumam realizar finalização plagal; enquanto o grupo de controle, meninas corumbaenses alfabetizadas, produzia a finalização autêntica, mais grave e assimétrica em relação às demais informantes.

Conforme vemos no gráfico apresentado a seguir, a média calculada do TM do controle, chamado de meninas, é 41, enquanto o tom final é 38, gerando uma diferença percentual de 7,3\%; todavia as médias das senhoras corumbaenses e guatós são coincidentes: 40 e 37 , respectivamente, para ambos os tons.

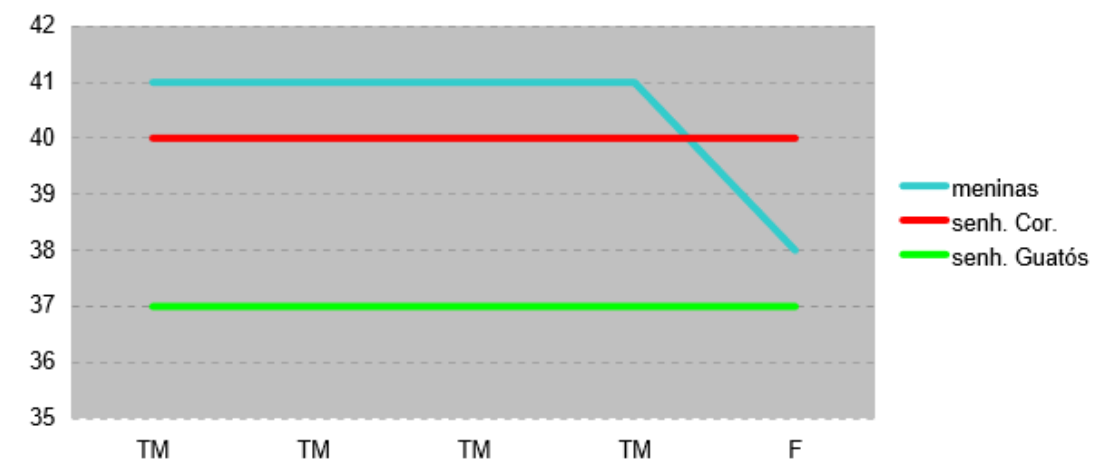

Gráfico 19: comparação entre as finalizações das entrevistadas corumbaenses. $O$ eixo vertical refere-se às médias medidas em Hertz, e a horizontal refere-se ao Tom Médio e o Tom Final decorrente das falas (COSTA, 2011, p.93)

A pesquisa de Baz (2011) traz resultados semelhantes. A autora comparou cantos e falas dos índios guaranis paraguaios, sendo que, dos cantos, obtiveram-se 39 finalizações plagais e 11 autênticas; nas falas, ocorreram 39 finalizações plagais e, apenas, 13 autênticas. Ou seja, o predomínio de finalizações plagais na fala é $66 \%$ maior do que as autênticas, enquanto no canto é $71 \%$ maior. 


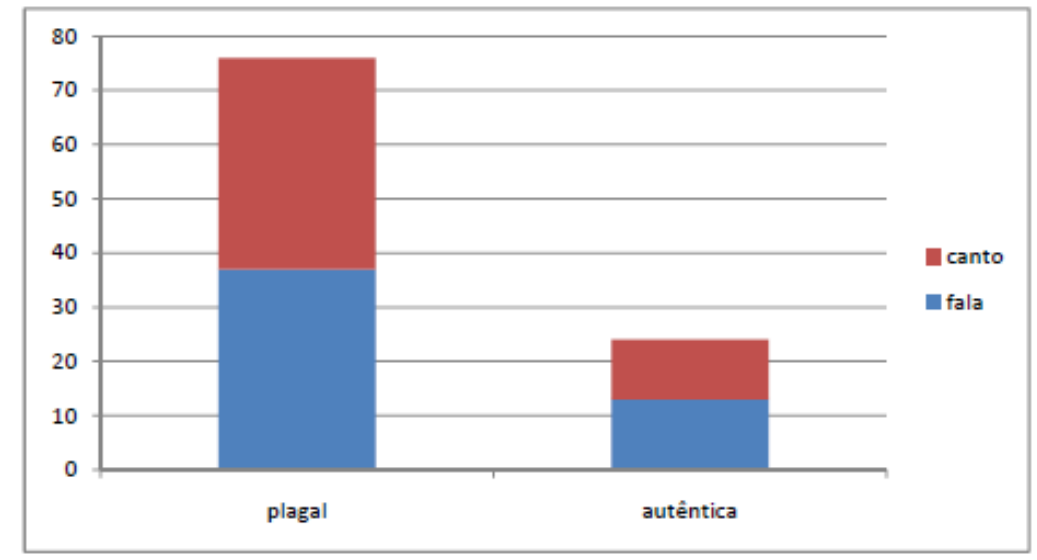

Gráfico 20: comparação entre o canto e a fala dos homens e mulheres guaranis paraguaios (BAZ, 2011, p.153)

Assim sendo, concluímos que:

1. A finalização plagal não está relacionada a uma etnia específica. Por isso, não é possível dizer que a entoação do dialeto caipira apresenta influência de índios ou de portugueses, pois, buscando informantes de diferentes regiões (portugueses, brasileiros, guatós e guaranis paraguaios), o traço plagal foi comum em todos que tinham baixo grau de instrução.

2. A escolarização é fator determinante na estruturação dos elementos prosódicos, pois ela define que seus falantes produzam uma finalização autêntica. Desta forma, se o falante passou por um processo de escolarização superficial, ou simplesmente não o teve, ele tende a continuar apresentando finalizações plagais.

3. Conforme visto no capítulo 3, o dialeto caipira possui um TM ou TF muitas vezes coincidente com a entoação das cidades portuguesas e com a do controle. Assim, atualizou-se a menção de Amaral (1920, p.56) que diz: "O tom geral do frasear é lento, plano e igual, sem a variedade de inflexões, de andamentos e esfumaturas que enriquece a expressão das emoções na pronunciação portuguesa", pois, como visto, o TM e TF de ambas as regiões são semelhantes.

Destarte, por enquanto o dialeto caipira pode ser caracterizado por um falar que: conserva diversas variações linguísticas; traz inflexões em sua fala, sendo comparável a outros dialetos; e possui uma finalização predominantemente plagal. No entanto, este trabalho apenas abre as portas para novas pesquisas sobre a prosódia caipira, cujos estudos apenas começaram. 


\section{REFERÊNCIAS}




\section{Referências}

ABAURRE, M. B. M. A relevância dos critérios prosódicos e semânticos na elaboração de hipóteses sobre segmentação na escrita inicial. Boletim da Abralin, 1991.

ALMEIDA, E. J. "Viola quebrada": linguagem e estilo característicos do falar caipira. In: Polifonia. no 2, vol. 12. Cuiabá: EduFMT, 2006, p. 91-105.

ALMEIDA, M. V. de. Edição de documentos do século XIX para o estudo da variedade linguística em Porto Feliz. 2007. 433 p. Dissertação (Mestrado em Língua Portuguesa. Área de concentração: Filologia). Faculdade de Filosofia, Letras e Ciências Humanas, Universidade de São Paulo, São Paulo.

ALMEIDA, B. P. Cronologia Tieteense. vol.1-2. São Paulo: Milesi, 1980.

ALMEIDA, J. C. F. Entre engenhos e canaviais: senhoras do açúcar em Itu (1780 1830). 2008. 120 p. Dissertação (Mestrado em Língua Portuguesa. Área de concentração: História Econômica). Faculdade de Filosofia, Letras e Ciências Humanas, Universidade de São Paulo, São Paulo.

AMARAL, A. O dialeto caipira. São Paulo: Anhembi, 1955.

ARAGÃO, M. do S. S. de. Ditongação x monotongação no falar de Fortaleza. Ceará: Universidade Federal do Ceará, 2009. Disponível em http://www. profala.ufc.br/trabalho9.pdf. Acesso em 04 fev 2012.

ARAÚJO, A. C. B. As invasões francesas e a afirmação das ideias liberais. In MATTOSO, J (dir.). História de Portugal, Volume 5, Lisboa: Círculo de Leitores, 1993. p. $17-43$

ARAÚJO, D. L. A língua falada na tv: texto falado ou escrito? In: Linguagem e ensino. (UCPel), Pelotas, v. 6, n.1, 2003. p. 57-76. Disponível em http://www.rle.ucpel.tche.br/index.php/rle/index. Acesso em 27 mar. 2015.

ARAÚJO, G. A.; et alii. Algumas observações sobre as proparoxítonas e o sistema acentual do português. In: Cadernos de estudos linguísticos, vol. 50, nº 1, 2008.

ARAÚJO, S. S. de F. Os falares regionais brasileiros à luz da sócio-história do português do Brasil. In: XI Encontro Regional de Estudantes de Letras/ Nordeste (XI EREL). Feira de Santana: UEFS, 2009. Disponível em www.uefs.br/erel2009/anais/silvanaaraujo.doc. Acesso em 25 jan 2012.

BABILÔNIA BRANDÃO, L. D’V. O processo de monotongação na fala culta Manauara. Amazonas: Universidade do Estado do Amazonas, s/d. Disponível em http://www.famac-uea.com.br/arquivos/o-processo-de-monotongacao-na-fala-cultamanauara-brandao.pdf. Acesso em 20 jan. 2012.

BAGNO, M. Nada na língua é por acaso: por uma pedagogia da variação linguística na sala de aula. São Paulo: Parábola Editora, 2007.

BARBOSA, A. O. Brasilienses e a ideia do não-sotaque no processo de formação de identidade linguística. 2002. 83 p. Dissertação (Mestrado em Língua Portuguesa. Área 
de concentração: Linguística). Instituto de Estudos da Linguagem, Universidade Estadual de Campinas, São Paulo.

BARBOSA, P. A. Conhecendo melhor a prosódia: aspectos teóricos e metodológicos daquilo que molda nossa enunciação. In: Revista de Estudos da Linguagem, Belo Horizonte, v. 20, n. 1, jan./jun. 2012. p. 11-27. Disponível em http://www.periodicos. letras.ufmg.br/index.php/relin/article/viewFile/2571/2523. Acesso em 07 jan. 2015.

BARRETO, L. Quase doutor. Disponível em http://www.portalsaofrancisco.com.br/ alfa/lima-barreto/quase-doutor.php. Acesso em 27 dez. 2014.

BARROS, J. Compilação de varias obras do insigne portuguez João de Barros. Lisboa: Officina de José da Silva Nazareth, 1785.

BARROS, R. C. R. A natureza linguística da alfabetização: aspectos prosódicos. In Signótica. V. 6. Goiás: UFG, 1994. p. 119-129.

BARTOLI, M. Saggi di linguística spaziale. Torino, 1945.

BASSETTO, B. F. Elementos de Filologia Românica. São Paulo: Edusp. 2001.

BATTISTI, E. A redução dos ditongos nasais átonos. In: BISOL, Leda; BRESCANCINI, C. (Orgs.). Fonologia e Variação. Recortes do Português Brasileiro. Porto Alegre: EDIPUCRS, 2002.

BAZ, D. G. M. As relações entre entoação frasal e melodia de músicas populares paraguaias. 2011, 161 p. Tese (Doutorado em Língua Portuguesa. Área de concentração: Fonologia). Faculdade de Filosofia, Letras e Ciências Humanas, Universidade de São Paulo, São Paulo.

BERTOLAZZI, C. História e política: como tudo começou em Itu. In: Projetos Municípios Digitais. 2009. Disponível em http://www.itu.com.br/politicanacional/noticia/historia-e-politica-como-tudo-comecou-em-itu-20100201. Acesso em 24 nov. 2013.

BISOL, L. A nasalidade, um velho tema. In: DELTA. Documentação de Estudos em Linguística Teórica e Aplicada, v. 14, n. especial. São Paulo: PUC, 1998. p. 24-46,

BISOL, L. A neutralização das átonas. In: DELTA. Documentação de Estudos em Linguística Teórica e Aplicada. v. 19. São Paulo: PUCSP, 2003. p. 267-276.

BISOL, L. A neutralização das átonas. In: Revista Letras (Curitiba), v. 61. Paraná: UFPR, 2003. p. 273-283.

BISOL, L. A Simetria no Sistema Vocálico do Português Brasileiro. Linguística - In: Revista de estudos linguísticos da Universidade do Porto, v. 5. Porto: Universidade do Porto, 2010. p. 41-52.

BISOL, L. O troqueu silábico no sistema fonológico (um adendo ao artigo de Plínio Barbosa). In: D.E.L.T.A., Vol. 16, N. ${ }^{\circ}$ 2. São Paulo: PUC, 2000. p. 403-413.

BISOL, L.; MAGALHÃES, J. S. A redução vocálica no português brasileiro: avaliação via restrições. In: Revista da Abralin, v. III, 2004. p. 195-216.

BORBA, F. S. Introdução aos estudos linguísticos. 4.ed. São Paulo, Ed. Nacional, 1975. 
BORTONI-RICARDO, S. Educação em língua materna: a Sociolinguística em sala de aula. São Paulo: Parábola Editorial, 2004.

BOTELHO, J. M.; LEITE, I. L. Metaplasmos contemporâneos - Um estudo acerca das atuais transformações fonéticas da Língua Portuguesa, 2009. Disponível em: http://www.filologia.org.br/cluerjsg/anais/ii/completos/comunicacoes/ isabellelins leite.pdf, acesso em 03 fev. 2012.

BOXER, C. R. A idade do ouro no Brasil: dores de crescimento de uma sociedade colonial. São Paulo: Companhia Editora Nacional, 1963.

BRANCO, M. J. Portugal no Reino de León: etapas de uma relação (866-1179). In El reino de León en la alta edad media: la monarquia (1109-1230). Vol. 4. Léon: Archivo Historico y Diocesano, 1993. p. 537-623

BUENO, S. Estudos de filologia portuguesa. 6a ed. São Paulo: Saraiva, 1967.

CAGLIARI, L. C. Alfabetização \& linguística. 10.ed. São Paulo: Scipione, 2002.

CAGLIARI, L. C. Elementos de fonética do português brasileiro. São Paulo: Paulistana, 2007.

CALLOU, D. M. I; LEITE, Y. Como falam os brasileiros. Rio de Janeiro: Zahar, 2002.

CAMPOS, B. M. S. O alteamento vocálico em posição pretônica no português falado em Mocajuba: A atuação da escolaridade e da faixa etária. In: III Jornada Cametaense De Letras. Língua, Literatura e outras linguagens: sujeitos, objetos e ensino na Amazônia. Cametá-Pará, 2010. p. 74-99.

CAMPOS, J. Porto Feliz histórico. Itu: Ottoni, 2003.

CAMPOS, V. S. Fundações Municipais Paulistas Nos Séculos XVIII e XIX. Volume 1. São Paulo: Impres, 1952.

CANDIDO, A. Os parceiros do Rio Bonito: estudo sobre o caipira paulista e a transformação dos seus meios de vida. 8. ed. São Paulo: Duas Cidades, 1998.

CARDOZO, S. e FERREIRA, C. A dialetologia no Brasil. São Paulo: Contexto, 1994.

CARMO JR, J. R. Melodia e prosódia: um modelo para interface música-fala com base no estudo comparado do aparelho fonador e dos instrumentos musicais reais e virtuais. 2007, 161 p.192. Tese (Doutorado em Linguística. Área de concentração: Semiótica e Linguística em geral). Faculdade de Filosofia, Letras e Ciências Humanas, Universidade de São Paulo, São Paulo.

CASTILHO, A. T. Nova Gramática do Português Brasileiro. São Paulo: Contexto, 2010.

CATEN, C. S.; RIBEIRO, J. L. D. Controle estatístico de processo: Cartas de controle para variáveis, cartas de controle para atributos, função de perda quadrática, análise de sistemas de medição. Rio Grande do Sul: FEENG, 2012.

CASTRO, V. S. A resistência de traços do dialeto caipira: estudo com base em atlas linguísticos regionais brasileiros. Tese de doutorado. Campinas: Universidade Estadual de Campinas. Instituto de Estudos da Linguagem, 2006. 
CESCHIN, O. H. L. A respeito de Amadeu Amaral e d'O dialeto caipira. Revista Lingua e Literatura, 25, 1999, p. 41-80.

CHACON, L. Ritmo da escrita. Uma organização do heterogêneo da linguagem. São Paulo; Martins Fontes, 1998.

CHAVES, L. M. N.; SANTOS, F. L. C. A realização das vogais médias átonas finais nas cartas fonéticas do Alto Acre. In: Cadernos do CNLF, Vol. XV, $\mathrm{N}^{\circ}$ 5, t. 2 . Rio de Janeiro: CiFEFiL, 2011. p. 1400-1413.

CHOMSKY, N. Aspects of the theory of syntax. Massachusetts: MIT, 1965.

COHEN, A.; t'HART, J. On the anatomy of intonation. Lingua, Leiden, v. 19, n. 2, 1967. p. 177-19.

CONSONI, F. Aspectos da percepção da proeminência tonal em português brasileiro. 2010. 132 p. Tese (Doutorado em Língua Portuguesa. Área de concentração: Fonologia). Faculdade de Filosofia, Letras e Ciências Humanas, Universidade de São Paulo, São Paulo.

COSTA, A. No Minho, 2.a ed. Porto, 1910. p. 250-251.

COSTA, L. T. Estudo do rotacismo: variação entre consoantes líquidas. Dissertação de mestrado. Rio Grande do Sul: Universidade Federal do Rio Grande do Sul. Instituto de Letras, 2006.

COSTA, N.S.A. Variações entoacionais na língua portuguesa falada por idosos guatós e não-índios. ms. In: EPOG, São Paulo, 2009.

COSTA, N.S.A. Variações entoacionais na língua portuguesa falada por mulheres guatós. 2011. Tese (Doutorado em Língua Portuguesa. Área de concentração: Fonologia). Faculdade de Filosofia, Letras e Ciências Humanas, Universidade de São Paulo, São Paulo.

COX, M. I. P.; ASSAD, C. F. O ele e o erre só trazem 'compricação' - um estudo das representações de /// e /r/ na escrita de crianças em processo de alfabetização. Revista de Educação Pública, v. 8, n. 13, 1999. p. 143-156.

CUNHA, A. P. N. A hipo e a hipersegmentação nos dados de aquisição da escrita: um estudo sobre a influência da prosódia. Dissertação de mestrado. Rio Grande do Sul: Universidade Federal de Pelotas. Pelotas, 2004.

CUNHA, A. P. N; MIRANDA, A. R. M. A hipo e a hipersegmentação nos dados de aquisição de escrita: a influência da prosódia. In Alfa, n. 53. São Paulo, 2009. p. 127148.

CUNHA, C. F. Conservação e inovação do português do Brasil. In: O eixo e a roda. Belo Horizonte, 1986.

DA HORA, D.; TELLES, S.; MONARETTO, V. N.O. Português brasileiro: uma língua de metátese? In: Letras de Hoje. Porto Alegre, v. 42, n. 2, p. 178-196, setembro 2007.

DESCAMPS, P. Portugal, la vie sociale actuelle. Paris: Firmin-Didot, 1935.

DI CRISTO, A. Interpreter la prosodie. In: XXIIIEMES JOURNEES D'ETUDE SUR LA PAROLE, Aussois, 13-23 jun 2000, p. 13-29. 
DIÉGUES JÚNIOR, M. Regiões culturais do Brasil. Rio de Janeiro: Centro Brasileiro de Pesquisas Educacionais, INEP, Ministério da Educação e Cultura, 1960.

DOLHNIKOFF, M. O pacto imperial: origens do federalismo no Brasil. São Paulo: Globo, 2005.

DUARTE, P. Prefácio. In: AMARAL, A. O dialeto caipira. São Paulo: Anhembi. 1955.

DUBOIS, J.; et al. Dicionário de linguística. São Paulo: Cultrix, 2001.

FALÉ, I.; FARIA, I.H. Percepção Categorial de contrastes entoacionais em Português Europeu. Actas do XXI Congresso da Associação Portuguesa de Linguística, Porto, 2006. p. 341-348.

FERNANDES, A. (coord.). Bragança marca a história, a história marca Bragança. Bragança: Câmara Municipal, 2009.

FERREIRA, C. R. G. A relevância de dados sobre a aquisição da escrita para as reflexões e práticas pedagógicas. In: $17^{\circ}$ CONGRESSO DE LEITURA DO BRASIL, 2009, Campinas. Disponível em http://alb.com.br/arquivo-morto/edicoes_anteriores/ anais17/txtcompletos/sem13/COLE_3864.pdf . Acesso em 28 jul. 2015.

FERREIRA, H. Educação: Minerva tardou a abençoar-nos. In Bragança marca a História, a História marca Bragança, Bragança: Câmara Municipal, 2009. p. 79-86.

FERREIRA NETTO, W. A entoação da língua portuguesa. Aula para concurso de professor títulos na Universidade de São Paulo, Faculdade de Filosofia, Letras e Ciências Humanas. São Paulo, 2010.

FERREIRA NETTO, W. As entrevistas abertas: uma técnica para verificar a variação linguística entre os interlocutores. Alfa: Revista de Linguística (UNESP. São José do Rio Preto. Impresso), v. 34, 1991. p. 129-142.

FERREIRA NETTO, W. Decomposição da entoação frasal em componentes estruturadoras e em componentes semântico-funcionais. In: IV CONGRESSO INTERNACIONAL DE FONÉTICA E FONOLOGIA, 2008, Niterói. Caderno de Resumos. Niterói: UFF, 2008. v. 1. p. 26-27.

FERREIRA NETTO, W. ExProsodia. Revista da Propriedade Industrial - RPI , 2038, pág. 167, item 120, em 26/out/2010. Disponível em http://revistas.inpi.gov.br /pdf/PATENTES2038.pdf Acesso em 20 jul 2013.

FERREIRA NETTO, W. Introdução à fonologia da língua portuguesa. São Paulo: Hedra, 2001.

FERREIRA NETTO, W. Variação tonal na finalização de frases de PB. III Colóquio Brasileiro de Prosódia. UFMG, 2011.

FERREIRA NETTO, W. Tradição oral e produção de narrativas. 1. ed. São Paulo: Paulistana, 2008. 103 p.

FERREIRA NETTO, W. Variação de frequência e constituição da prosódia da língua portuguesa. 2006. Tese (Livre-Docência em Língua Portuguesa. Área de concentração: Fonologia). Faculdade de Filosofia, Letras e Ciências Humanas, Universidade de São Paulo, São Paulo. 
FERREIRA NETTO, W.; BAZ, D. G. M. Variação tonal na finalização de frases de PB. In Academia.edu. 2011. Disponível em https://www.academia.edu/2272642/ Variacao_tonal_na finalizacao_de frases_de_PB. Acesso em 07 jan. 2014.

FERREIRA NETTO, W. ; CONSONI, F. Estratégias prosódicas da leitura em voz alta e da fala espontânea. Alfa: Revista de Linguística (UNESP. São José do Rio Preto. Online), v. 52, 2008. p. 521-534.

FERREIRA NETTO, W.; CONSONI, F.; PERES, D. O. Finalizações de frase em leituras e frases espontâneas em PB. In: 57 SEMINÁRIO DO GEL, 2009, Ribeirão Preto: UNAERP. Jul. 2009. Disponível em https://www.academia.edu/2272648/ Finalizacoes de frase em leituras e fala espontanea no_PB. Acesso em 08 jan. 2014.

FERREIRA NETTO, W.; MARTINS, M. V. M.; Prosódia e escalas de frequência: um estudo em torno da escala de semitons. In ReVEL, v. 8, n. 15, 2010. Disponível em http://www.revel.inf.br/files/artigos/revel_15 prosodia_e escalas de frequencia.pdf.

Acesso em 06 jan 2014.

FERREIRA NETTO, W.; MARTINS, M.V.M.; VIEIRA, M. F. Efeitos da entoação e da duração na análise automática das manifestações emocionais. In: $61^{\circ}$ SEMINÁRIO DO GEL, 2013. Disponível em http://usp-br.academia.edu/Waldemar FerreiraNetto. Acesso em 14 jul 2013.

FOLMER-JOHNSON, T. N. O. Oscilações, ondas, acústica. São Paulo: Nobel, 1968.

FONSECA, J. Novo diccionario da lingua portugueza: seguido de um diccionario completo dos synonymos portuguezes. Paris: J.P. Aillaud, 1833.

FRANÇA, S. A. O apagamento da vogal postônica não-final por falantes de Jaru Estado de Rondônia. In: Acta Scientiarum. Language and Culture, Maringá, v. 31, n. 2, 2009. p. 169-182.

FreitaG, R. M. K.; ARAUJO, A. S.; BARRETO, E. A.; CARVAlHO, E. S. S. Vamos prantar frores no grobo da terra: estudando o rotacismo nas séries iniciais da rede municipal de ensino de Moita Bonita/se, In: RevLet - Revista Virtual de Letras, Volume 2, Número 02, 2010.

FREITAS, S. N. de. As vogais médias pretônicas no falar da cidade de Bragança. Dissertação de Mestrado. Pará: Universidade Federal do Pará, 2001.

Fundação SEADE. Pirapora do Bom Jesus. In: Perfil municipal. 2013. Disponível em: http://www.seade.gov.br/produtos/perfil/hist/hist_391.pdf. Acesso em 25 nov. 2013.

GARBER, R. Análise de séries temporais. In: PERES NETO, P.R.; VALENTIN, J . L.; FERNANDEZ, F. A. S. Oecologia Brasiliensis: Tópicos em tratamento de dados biológicos. V.2. Rio de Janeiro: UERJ, 1995. p. 91-118.

GARCIA, R.R. Os metaplasmo de Amaral: demonstração de variações caipira ou brasileira? In Anais de resumos do II Congresso Internacional de Linguística Histórica. São Paulo: USP, 2012. p. 786-790.

GARCIA, R. R. Para o estudo da formação e expansão do dialeto caipira em Capivari. 2009. 667 p. Dissertação (Mestrado em Língua Portuguesa. Área de concentração: 
Filologia). Faculdade de Filosofia, Letras e Ciências Humanas, Universidade de São Paulo, São Paulo.

GARCIA, R. R.; DA SILVA, A. B. Testemunhos da educação no interior de São Paulo no século XIX: relatos provenientes do labor filológico. In: Linguagem. Estudos e Pesquisas (UFG), v. 16, 2012. p. 289-310.

GIANNI FONTIS, C. As vogais médias pretônicas na fala culta de Nova Venécia - ES. Dissertação de mestrado. Campinas: Universidade Estadual de Campinas. Instituto de Estudos da Linguagem, 2004.

GREGORIO, E. A terra dos exageros. In Revista regional: Itu, Salto, Indaiatuba. 2011. Disponível em http://revistaregional.com.br/portal/?p=588. Acesso em $06 \mathrm{dez} 2013$.

HAUY, A. B. Séculos XII, XIII e XIV. In: SPINA, Segismundo (Org.). História da Língua Portuguesa. São Paulo: Ateliê Editorial, pp. 21-141, 2008.

HERCULANO, A. História de Portugal. $2^{\mathrm{a}}$ ed. Lisboa: Imprensa Nacional, 1863.

HOLANDA, S. B. Monções. v. 8. São Paulo: Alfa-Ômega, 1976.

HOLANDA, S. B. Raízes do Brasil. 26ª ed. São Paulo: Companhia das Letras, 1995.

HOSOKAWA, A. B. de S.; SILVA, P. S. Harmonização vocálica do /e/ e do /o/ no município de Rio Branco - Acre. In: Cadernos do CNLF, Vol. XIV, No 4, t. 3, 2010. p. 2715-2727.

HOUAISS, A.; VILLAR, M. de S. Dicionário Eletrônico Houaiss da Língua Portuguesa. Rio de Janeiro: Objetiva, 2001.

HUCKVALE, M.A. Speech Filing System v.4.7/Windows SFSWin Version 1.7, em 17/02/2008. Disponível para download em <http://www.phon.ucl.ac.uk/resource/sfs> . Acesso em 20 jul. 2013.

IBGE. Pessoas de 10 anos ou mais de idade, total e analfabetas, por Grandes Regioes, segundo os grupos de idade e o sexo - 2009/2011. Disponível em ftp://ftp.ibge.gov.br/ Trabalho_e_Rendimento/Pesquisa_Nacional_por_Amostra_de_Domicilios_anual/2011/ tabelas_pdf/sintese_ind_3_1.pdf. Acesso em 17 fev. 2015.

KATO, M. A. No mundo da escrita: uma perspectiva psicolinguística. São Paulo: Ática, 1986.

KUHL, P.K.; IVERSO, P. A new view of language acquisition. Proceedings of the National Academy of Sciences, n. 97, v.22, p. 1850-1857, 2000.

KUHL, P.K.; IVERSON, P. Linguistic experience and the "perceptual magnet effect". In: STRANGE, W. (ed.). Speech perception and linguistic experience: issues in crosslanguage research. Baltimore: York Press, 1995. p. 121-154.

KUHL, P.K.; TSAO, F.-M.; LIU, H.-L.; ZAHNG, Y.; DE BOER, B. Language / Culture / Mind / Brain. Progress at the margins between disciplines. Annals of New York Academy of Sciences, n. 935, 2001. p. 136-74.

LABOV, W. Principles of linguistic change: Social factors. In the series, Language in Society 29. V.2. Malden, MA: Blackwell Publishers, Inc. 2001. 
LEITE, D. R. Estudo prosódico sobre as manifestações de foco. Dissertação de Mestrado. Minas Gerais: Universidade Federal de Minas Gerais, 2009.

LEITE, J. C. O Brasil e a emigração portuguesa (1855-1914). In: Fazer a América: imigração em massa para a América Latina. São Paulo: EDUSP, 1999. p.177-200

LEMOS, F. S. Da Proto-história à romanização. In Bragança marca a História, a História marca Bragança, Bragança: Câmara Municipal, 2009. p. 103-111.

LEVADO, R. F. Para o estudo da formação e expansão da cultura e do dialeto caipira na região de Tietê. Dissertação de mestrado, São Paulo: Universidade de São Paulo, 2009.

LIEBERMAN, P. Intonation, perception, and language. Cambridge: The MIT Press, 1967.

LIMA, M. R. R. Harmonia: uma abordagem prática. Parte 1. São Paulo: Embraform, 2010.

LIMA, B.; BACELLAR, M. Diccionario da lingua portugueza: em que se acharão dobradas palavras do que traz Bluteau e todos os mais diccionaristas juntos: a sua propria significação: as raizes de todas ellas: a accentuação: e a selecção das mais usadas, e polidas. Lisboa: Na Officina de Jozé de Aquino Bulhoens, 1783.

LOPES, R. A realização variável dos ditongos low/ e lej/ no português falado em Altamira/PA. Dissertação de mestrado: Universidade Federal do Pará, 2002.

MAEDA, S. A characterization of American English intonation. 1976. Doutorado. Massachussets Institute of Technology, Boston.

MARTINS, F. S.; MAIA, E. G. A realização da vogal posterior média fechada, em posição tônica, nos municípios de Parintins, Tefé, Itacoatiara e Manacapuru. Amazonas: Universidade Federal do Amazonas, s/d. Disponível em www.letrasamazonicas.ufam.edu.br. Acesso em 24 jan. 2012.

MARTINS, J. S. O migrante brasileiro na São Paulo estrangeira. In: PORTA, Paula (org.). História da Cidade de São Paulo, 3 vols., Volume 3: A cidade na primeira metade do século XX - 1890-1954. São Paulo: Paz e Terra, 2004, p. 153-213.

MARTINS, M.; DELGADO, M. História e arqueologia de uma cidade em devir: Bracara Augusta. In Cadernos de Arqueologia, série 2. Braga: Unidade de Arqueologia da Universidade do Minho, 1989. p. 11-38. Disponível em http://repositorium.sdum. uminho.pt/bitstream/1822/10268/1/CA\%206_7\%20Hist\%C3\%B3ria\%20e\%20arqueolo gia\%20de\%20uma\%20cidade...\%20.pdf. Acesso em 05 jan. 2015.

MARTINS, N. S. Século XIX. In: SPINA, Segismundo (Org.). História da Língua Portuguesa. São Paulo: Ateliê Editorial, pp. 429-511, 2008.

MARQUES, R. O comércio na dinamização da reabilitação urbana. In Correio do Minho. 24 out. 2014. Disponível em http://www.correiodominho.com/cronicas.php? $\underline{\mathrm{id}=6239}$. Acesso em 05 jan 2015. 
MATOS, J. P. B; PACHECO, V.; LEITE, C. M. B. Estudo contrastivo dos ambientes fonológicos propiciadores do alçamento de /e/>/i/ e /o/>/u. In: Anais do III Seminário de Pesquisa em Estudos Linguísticos e III Seminário de Pesquisa de Análise do Discurso. Vitória da Conquista: Edições UESB, 2007. p. 59-64.

MATTOS E SILVA, R. V. O português arcaico: fonologia, morfologia e sintaxe. São Paulo: Contexto, 2006.

McEVEDY, Colin. Atlas da história medieval. São Paulo: Companhia das Letras, 2007.

MEDEIROS, B. R. Em busca do som perdido: o que há entre a linguística e a música. In: ILARI, B. S. (Org.). Em busca da mente musical: ensaios sobre os processos cognitivos em música - da percepção à produção. Curitiba: UFPR, 2006.

MENDES, C. M. O falar do Jornal Nacional: produção e recepção de um sotaque de natureza ideológica. 2006. 104 p. Monografia (Bacharel em Jornalismo. Área de concentração: Comunicação Social). Universidade Federal de Minas Gerais, São Paulo.

MENDONÇA, R. O português do Brasil. Rio de Janeiro: Civilização Brasileira, 1936.

MIGLIORINI, L.; MASSINI-CAGLIARI, G. A epêntese vocálica no português brasileiro: regra lexical ou pós-lexical? In: Revista Todas as Letras. v. 13, n. 1, 2011. p. 72-84.

MIRA MATEUS, M. H. Estudando a melodia da fala: traços prosódicos e constituintes prosódicos. Palavras - Disponível em http://www.iltec.pt/pdf/wpapers/2004mhmateus-prosodia.pdf. Acesso em 19 dez 2011.

MORAES, J. A. Intonational Phonology of Brazilian Portuguese, ms. In Workshop on Intonational Phonology: understudied or fieldwork languages, ICPhS 2007. Satellite Meeting, Saarbrucken, 5 ago 2007.

MORAIS E SILVA, A.; BLUTEAU, R. Diccionario da lingua portugueza. Lisboa: Officina de S. T. Ferreira, 1789.

MORETTIN, P.A.; TOLOI, C.M. Séries temporais. São Paulo: Atual, 1986.

MOTA, C. Edição de documentos oitocentistas e estudo da variedade linguística em Santana de Parnaíba. 2007. 466 p. Dissertação (Mestrado em Língua Portuguesa. Área de concentração: Filologia). Faculdade de Filosofia, Letras e Ciências Humanas, Universidade de São Paulo, São Paulo.

MOURA, C. Q. P.; FERREIRA, J. S. S. R. Metaplasmos no falar urbano montebelense: um estudo sobre apócope e vocalização. In: ÍCONE - Revista de Letras, São Luís de Montes Belos, v. 2, p. 196-210, jul. 2008.

MURRAY, I. R.; ARNOTT, J. L.: Towards the Simulation of Emotion in Synthetic Speech: A Review of the Literature of Human Vocal Emotion. Journal of Acoustic Society of America, New York, v. 93, n. 2, 1993. p. 1097-1198.

NASCENTES, A. O linguajar carioca. Rio de Janeiro: Organização Simões, 1953.

NEPOMUCENO, L. X. .Acústica técnica. São Paulo: Etegil, 1968. 
NESPOR, M.; VOGEL, I. La prosodia. Madrid: Visor Distribuciones, 1994.

NEWITT, M. D. D. A History of Portuguese Overseas Expansion 1400-1668. Nova Iorque: Routledge, 2005.

NOLL, V. O português brasileiro: formação e contrastes. Tradução de Mário Eduardo Viaro. São Paulo: Globo, 2008.

NOVO DICCIONARIO da lingua portugueza: composto sobre os que até o presente se tem dader ao prelo, e accrescentadode varios vocabulos extrahidos dos classicos antigos, e dos modernos de melhor nota, que se achaõ universalmente recebidos. Lisboa: Typografia Rollandiana, 1806.

NUNES, J. J. Compêndio de Gramática Histórica Portuguesa. Lisboa: Clássica Editora, 1989.

OLIVEIRA, C.; TEIXEIRA, A. Guia Prático - Praat. Escolar Superior de Saúde da cidade de Aveiro, 2006.

OLIVEIRA, F. A gramática da linguagem portuguesa - Introdução, leitura actualizada e notas por M. L. Buesco. Lisboa: Imprensa Nacional - Casa da Moeda, 1975.

OLIVEIRA, K. O verso e o reverso: redução de ditongos e ditongação em textos escritos por negros no Brasil Oitocentista. In: Signum: Estudos da Linguagem, v. 11, n. 2, 2008. p. 155-175.

OLIVEIRA, M. A representação do caipira na imprensa paulista do século XIX. In: DUARTE, M. E. \& CALlOU, D.(orgs.) Para a História do Português Brasileiro, volume IV, Rio de Janeiro: Faperj/UFRJ, 2002, p.125-154.

PACHECO, V. O efeito dos estímulos auditivo e visual na percepção dos marcadores prosódicos lexicais e gráficos usados na escrita do Português Brasileiro. 2006. 319 p. Tese (Doutorado em Linguística. Área de concentração: Linguística). Instituto de Estudos da Linguagem, Universidade Estadual de Campinas.

PAGOTTO, E. G. Introdução às ciências da linguagem: linguagem, história e conhecimento. In: PFEIFFER, Claudia C.; NUNES, José H. Linguagem, história e conhecimento: linguística histórica - Sociolinguística - Aquisição da linguagem Língua e Cognição - Conhecimento sobre linguagem. Campinas: Pontes Editores, 2006.

PAIVA, D. F. Séculos XV e meados do século XVI. In: SPINA, Segismundo (Org.). História da Língua Portuguesa. São Paulo: Ateliê Editorial, 2008. p. 147-273.

PETRONE, P. Aldeamentos Paulistas. São Paulo: Edusp, 1995.

PIERCE, J. R. The science of musical sounds. New York: Scientific American Library, 1987.

PIERREHUMBERT, J. The phonology and phonetics of English intonation. 1980. Doutorado. Massachusetts Institute of Technology, Boston.

PIERREHUMBERT, J.; BECKMAN, M. E. Japanese tone structure. Cambridge: The MIT Press, 1980.

PINTO, E. P. A gramatiquinha de Mário de Andrade: texto e contexto. São Paulo: ILivraria Duas Cidades, 1990 
PINTO, E. P. O português do Brasil: textos críticos e teóricos. V2. Rio de Janeiro: Livros técnicos e científicos, 1978.

PIRES, C. R. S. Aspectos linguísticos do dialeto caipira encontrados em manuscritos de Piracicaba do séc. XIX. In: Revista de Filologia e Linguística Portuguesa. Vol. 10/11. São Paulo: USP, 2009, p. 291-304.

PIRES, C. R. S. A formação e expansão da cultura e dialeto caipira na região de Piracicaba. 2008. 309 p. Dissertação (Mestrado em Língua Portuguesa. Área de concentração: Filologia). Faculdade de Filosofia, Letras e Ciências Humanas, Universidade de São Paulo, São Paulo.

PRAEM, G. C. O. História. In: Bom Jesus de Pirapora: Diocese de Jundiaí/SP. 2013. Disponível em http://sbj6.com.br/historia/. Acesso em 25 nov. 2013.

RAMOS, D. From Minho to Minas: the portuguese roots of the Mineiro Family. In Hispanic American Historical Review. n. 73, vol. 4, p. 639-662. nov. 1993, p. 648-651.

RAMOS, R. Culturas da alfabetização e culturas do analfabetismo em Portugal: uma introdução à História da Alfabetização no Portugal contemporâneo. In Análise Social, vol. XXIV (103-104), 1988. p. 1067-1145. Disponível em http://analisesocial.ics.ul.pt/ documentos/1223032571Q0nUJ7ty8Sg03SR3.pdf. Acesso em 02 jan. 015.

RÉVAH, I.S. (1958). A evolução da pronúncia em Portugal e no Brasil do século XVI aos nossos dias. In: $1^{o}$ Congresso Brasileiro De Língua Falada No Teatro, Salvador, 1956. Anais. Rio de Janeiro: MEC.

RIBEIRO, A. P. G. Jornal Nacional: a notícia faz história/Memória Globo. Jorge Zahar: Rio de Janeiro, 2004.

RIBEIRO, D. O povo brasileiro. A formação e o sentido do Brasil. São Paulo: Companhia das Letras, 2002.

RIBEIRO, J. História do Brasil. Rio de Janeiro: Livraria Cruz Coutinho, 1901.

ROCHA, M. J. M. Arquitectura Religiosa Barroca em Braga. In Revista da Faculdade de Letras. Ciências e Técnicas do Património. Porto, vol. IX-XI, 2010-2012. p. 331373. Disponível em http://ler.letras.up.pt/uploads/ficheiros/11403.pdf. Acesso em 05 jan. 2015.

RODRIGUES, A. N. O dialeto caipira na região de Piracicaba. São Paulo: Ática, 1974.

ROMERO, R. M. L. Estudo semântico-lexical na região de Itu. Dissertação de mestrado, São Paulo: Universidade de São Paulo, 2008.

SAINT-HILAIRE, A. Segunda viagem do Rio de Janeiro a Minas Gerais e São Paulo. (1822). São Paulo: Cia. Editora Nacional, 1932.

SAINT-HILAIRE, A. Viagem à província de São Paulo e resumo das viagens ao Brasil, Província Cisplatina e missões do Paraguai. São Paulo: Livraria Martins, 1940.

SANTANA, M. O. R. A idade média. In Bragança marca a História, a História marca Bragança, Bragança: Câmara Municipal, 2009. p. 113-121. 
SANTANA, A. R.; DANTAS, J. J.; SANTANA, M. J. B.; GUEDES, M. L.; FREITAG, R. M. K.. O tratamento do rotacismo nas séries iniciais da rede municipal de ensino de Ribeirópolis. In: SILVA, L. R.; FREITAG, R. M. K. (org.). Linguagem e representação discursiva. João Pessoa: Editora Universitária UFPB, 2008. p. 147-155.

SANTO ORCERO, M. F. R. A. Variação ditongo/monotongo no português de Caxias MA. Tese de doutorado. Araraquara: Universidade Estadual Paulista (UNESP), 2002.

SANTOS, I. O.; PACHECO, V.; SOUSA, V. V. Inventário de palavras com ditongo e monotongação de [aj], [ej] e [ow]. In: Anais do III Seminário de Pesquisa em Estudos Linguísticos e III Seminário de Pesquisa de Análise do Discurso. Vitória da Conquista: Edições UESB, 2007. p. 77-82.

SCHERER, K.R. Vocal affect expression: a review and a model for futures research. In Psychological Bulletin, V. 99, N. 2, 1986. p. 143-165.

SEQUEIRA, F. J. M. Apontamentos acerca do Falar do Baixo-Minho. Lisboa: Revista de Portugal, 1957.

SILVEIRA, R. C. P. Uma pronúncia do Português Brasileiro. São Paulo: Cortez, 2008.

SOUSA, F. Dos finais de seiscentos ao século XIX. In Bragança marca a História, a História marca Bragança, Bragança: Câmara Municipal, 2009. p. 173-190.

SOUSA, F. Vila Real: a memória de uma cidade. In Revista da Faculdade de Letras: História, Série II, vol. 6, 1989. p. 271-286. Disponível em http://ler.letras.up.pt/ uploads/ficheiros/2144.pdf. Acesso em 06 jan. 2015.

SOUSA, R. M. A Sociolinguística na Formação Docente. In: Aprendendo a aprender. FÉLIX, J. dArc B (org.). UniCEUB - Faculdade de Ciências da Educação - Guia de Formação para Professores das Séries Iniciais - Convênio com a Secretaria de Educação GDF, 2005.

SPENCER, H. The origin of music. In Popular science monthly. 1890. Disponível em http://en.wikisource.org/wiki/Popular_Science_Monthly/Volume_38/November_1890/ The_Origin_of_Music. Acesso em $07 \mathrm{fev} .2015$.

SPINA, S. (Org.). História da Língua Portuguesa. São Paulo: Ateliê Editorial, 2008.

TEYSSIER, P. La langue de Gil Vicente. Paris: Librairie C. Klincksieck, 1959.

TEYSSIER, P. Manuel de langue portugaise (Portugal-Brésil). $2^{\mathrm{a}}$ ed. Paris: Klincksieck, 1983.

T'HART, J.; COLlIER, R.; COHEN, A. A perceptual study of intonation: an experimental-phonetic approach to speech melody. Cambridge: Cambridge University Press, 1990.

TROUBETZKOY, N. S. Principes de phonologie. Trad. de J. Cantineau. Paris: Klincksieck, 1964.

STEELE, J. Prosodia Rationais: or an essay towards establishing the melody and measure of speech. London: J. Nichols, 1779. 
VASCONCELOS, J. L. Opúsculos: filologia. Vol. 1, parte 1. Coimbra: Imprensa da Universidade, 1928.

VASCONCELOS, J. L. Opúsculos: dialectologia. Vol. 2, parte 1. Coimbra: Imprensa da Universidade, 1928.

VASCONCELOS, J. L. Opúsculos: dialectologia. Vol. 4, parte 2. Coimbra: Imprensa da Universidade, 1985.

VASCONCELOS, J. L. Textos arcaicos. 3. ed. Ampl. Lisboa: Livraria Clássica, 1987.

VAISSIÈRE, J. Sur les universaux de substance prosodiques, In: WAUQUIER, S. (ed.) Les universaux sonores. Nantes: Presses Universitaires de Rennes, 2002. Disponível em: www.personnels.univ-paris3.fr/users/vaissier/pub/ARTICLES/index_fichiers/2005. pdf. Acesso em: 9 mar. 2007.

VASSOLER, A.O.; MARTINS, M.V.M. A entoação em falas teatrais: uma análise da raiva e da fala neutra. Estudos Linguísticos, São Paulo, v.42, n.1, p.8-18, Disponível em: <http://www.gel.org.br/estudoslinguisticos/volumes/42/EL-42_vol1_9 _18_AMO_Vassoler_MVM_Martins.pdf>.Acesso em 14 jul. 2013.

VIARO, M. E. Por trás das palavras. Manual de etimologia do português. São Paulo: Globo, 2004.

VIANNA, H.; LACOMBE, A. J. História do Brasil. Vol. 1. São Paulo: Edições Melhoramentos, 1974.

XU, Yi; WANG, Q.E. Component of intonation: what are linguistic, what are mechanical/physiological? Presented at International Conference on Voice Physiology and Biomechanics, Evanston Illinois, 1997. 